UC-70月

Issued: August 1982

$2 \times-0.405-1: 3$

DeC2 021837

\title{
Environmental Analysis of Acid/Middle Pueblo Canyon, Los Alamos, New Mexico
}

Roger W. Ferenbaugh

Thomas E. Buhl

Alan K. Stoker

Wayne R. Hansen

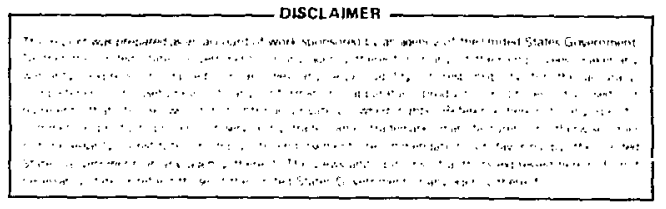

L(OS A)añOS Los Alamos National Laboratory 


\section{CONTENTS}

1.0 INTROOUCTION AND BACKGROUND

1.1 The FUSRAP Program

1.2 Preferred Alternative

2.0 ACID/PUEBLO CANYON 3

2.1 Summary History and Description 3

2.1.1 Description 3

2.1.2 History of Site 3

2.1.2.1 Operations and Waste Disposal 3

2.1.2.2 Decont amination and Decommissioning 10

2.1.2.3 Land Ownership 10

2.2 Need for Action 11

2.2.1 Potential Dose Evaluation and Interpretation 11

2.2.1.1 Bases of Dose Estimates and Comparisons 11

2.2.1.2 Potential Doses Under Present Conditions 12

2.2.1.3 Potential Doses Under Future Conditions 16

2.2.1.4 Potential Doses Associated with Cleanup 17

2.2.2 Health Risks from Acid/Puebio Residual Radioactivity 19

2.2.2.1 Risks from Existing Conditions 19

2.2.2.2 Risks from Cleanup 20

2.2.3 Criteria Upon Which Cleanup Action is Based 22

2.3 Other Agencies Involved in Implementation of the 23

Proposed Action

3.0 ALTERNATIVES 23

3.1 Alternative I--Minimal Action 25

3.2 Alternative II--Remedial Action (Preferred Alternative) 26

3.3 Alternative III--No Action 26

4.0 AFFECTED ENVIRONMENT 26

4.1 Land Use 26

4.1.1 Acid Canyon and the Fọrner TA-45 Site 26

4.1.2 Middle Pueblo Canyon 29

4.1.3 TA-54 28

4.1.4 Transportation Route $\quad 28$

$\begin{array}{lll}4.2 & \text { Socioeconomics } & 30\end{array}$

4.2.1 Demography 30

4.2 .2 Economy 30

4.2.3 Institutional 31

4.2.4 Community Services 32

4.2.5 Archaeology 32

4.3 Soil and Geology . 33

4.3 .1 Soils $\quad 33$

4.3.2 Geology $\quad 37$ 
4.4 Clinatology 40

4.4.1 General Climate $\quad 40$

4.4.2 Air Quality 41

4.5 Hydrology and Water Quality 41

4.6 Biotic Environmental Factors 42

4.6.1 General Ecology 42

4.6.2 Plants 43

4.6.2.1 Characterization 43

4.6.2.? Räre and Endanyered Speries 43

4.6.3 Animals 4 ?

4.6.3.1 Characterization 4?

4.6.3.2 Rare and Endanczered Species 47

4.7 Summary of Radiological Conditions 48

4.7.1 Radioactivity in Soils and Sediments 4 ?

4.7.1.1 Present Conditions 4 ?

4.7.1.2 Concentrations 50

4.7.1.3 Est imated Inventory 54

4.7.2 Airborne Radioactivity 56

4.7.2.1 Present Conditions 56

4.7.2.2 Measurements 56

4.7.2.3 Theoretical Estimates $\quad 60$

4.7.3 External Penetrating Radiation $\quad 61$

5.0 ENVIRONMENTAL CONSEQUENCES 61

5.1 Alternative I--Minimal Action 64

5.1.1 Radiological Consequences 64

5.1.2 Ecological Consequences 64

5.1 .3 Land Use Impacts 65

5.1.4 Socioeconomic Effects 65

5.1.5 Risk to Individual Health and Safety 65

5.2 Alternative I'--Remedial Action (Preferred Alternative) 66

5.2.1 Radiological Consequences 66

5.2.2 Ecological Consequences 66

5.2 .3 Land Use Impacts 67

5.2.4 Socioeconomic Effects 67

5.2.5 Risk to Individual Health and Safety 67

5.3 Alternative III--No Action 68

5.3.1 Radiological Consequences 68

5.3.2 Ecological Consequences 68

5.3.3 Land Use Impacts 68

5.3.4 Socioeconomic Effects 68

5.3.5 Risk to Individual Health and Saiety 68 
A. DOSE CALCULATIONS FOR TA-45/ACID CANYON CLEANUP 72

B. PLANTS OF PUEBLO CANYON 28

C. PLANTS ENUMERATED IN NEW MEXICO STATUTE 45-1-11 THAT ARE KNOWN TO OCCUR IN LOS ALAMOS COUNTY

D. ANIMALS OF THE LOS ALAMOS ENVIRONS

FIGURES

1. Regional location of study area

2. Physiographic setting of LoS Alamos County

3. Former liquid waste handling facilities and relation to effluent receiving canyons

4. Aerial view of Los Alamos and study area looking east 8

5. Location of proposed fence and areas of residual radioactivity 25

6. Debris on former TA-45 site 27

7. Location of TA-54 and transportation route from former TA-45 site 29

8. Geologic map of a part of the Pajarito Plateau in the Los Alamos 38 site

9. Concentration of ${ }^{239} \mathrm{pu}$ on soils and sediments by location 51

10. Estimated inventory of ${ }^{239} \mathrm{Pu}$ on soils and sediments by location 55

11. Concentrations of airborne $23 \mathrm{Pu}_{\mathrm{u}}$ at three locations during 59 1976-1977

A-1. Sampling locations and suminary results for areas of former treatment plant site to be cleaned up under Alternative II 
I. RADIOACTIVITY CONTENT OF EFFLUENTS RELEASED TO ACID CANYON 9

II. MAXIMUM LIKELY INCREMENTS OF RISK BASEO ON EXPOSURE

ATTRIBUTABLE TO RESIDUAL RADIOACTIVITY IN ACID AND MIDDLE

PUEBLO CANYONS

III. RISK COMPARISON DATA

IV. PROPOSED CRITERIA FOR SOIL CLEANUP ACTION 23

V. ACTIONS, ADVANTAGES, AND DISADVANTAGES ASSOCIÁTED WITH 24

ACID/PUEBLO CANYON ALTERNATIVES

VI. COMMON HERBS AND SHRUBS OF THE LOWER MIODLE PUEBLO CANYON AREA 44

VII. PLANTS OF TA-45/ACID/MIDDLE PUEBLO CANYON

VIII. MAMMALS TRAPPED OR SIGHTEO IN ACIO/PUEBLO CANYON 48

IX. STATE-LISTED ENDANGERED ANIMAL SPECIES FOR NORTHCENTRAL 49 NEW MEXICO

$X . \quad$ SEDIMENT ANALYSES FROM ACID CANYON 49

$X I . \quad$ SUIMMARY OF DATA 52

XII. RELATIONSHIP OF $239 \mathrm{PU}$ AND OTHER TRANSURANIC CONCENTRATIONS 57

XIII. ANNUAL AVERAGE 239PU AIR CONCENTRATIONS

XIV. POTENTIAL CONTRIBUTIONS OF RESUSPENSION TO $239 \mathrm{P}_{\mathrm{U}}$

AIRBORNE RADIOACTIVITY

XV. EXTERNAL PENETRATING RADIATION MEASUREMENTS AND ESTIMATES 63

OF CONTRIBUTIONS FROM RESIDUAL RADIOACTIVITY

APPENDIX TABLES

A-I. TREATMENT PLANT SITE RADIOLOGICAL ANALYSIS OF SELECTED SOIL 73 SAMPLES IN THE O TO 5-CM SOIL LAYER

A-II. AVERAGE RADIONUCLIDE CONCENTRATIONS IN SOIL ( $\mathrm{pCi} / \mathrm{g}$ ) IN THE 75 AREAS OF CLEANUP

A-III. ESTIMATED DOSES FROM CLEANUP OF FORMER WASTE TREATMENT SITE 78 (ALTERNATIVE II)

D-I. MAMMALS

D-II. AMPHIBIANS AND REPTILES

D-III. FISH

D-IV. BIRDS 93

D-V. INVERTEBRATES 100 


\section{ENVIRONMENTAL ANALYSIS OF ACID/MIDDLE PUEBLO CANYON, LOS ALAMOS, NEW MEXICO}

\section{by}

Roger W. Ferenbaugh, Thomas F. Buh1, Alan K. Stoker, and Wayne R. Hansen

\section{ABSTRACT}

The radiological survey of the former radioactive waste treatment plant site (TA-45), Acid Canyon, and Pueblo Canyon found residual radioactivity at the site itself and in the channel and banks of Acid, Pueblo, and lower Los Alamos Canyons, all the way to the Rio Grande. The largest reservoir of radioactive material is in lower Pueblo Canyon, which is on DOE property. The only areas where residual radioactivity exceeds the proposed cleanup criteria are at the former vehicle decontamination facility, located between the former treatment plant site and Acid Canyon, around the former untreated waste outfall and for a short distance below, and in two small areas farther down in Acid Canyon. The three alternatives proposed are (1) to take no action, (2) to fence the areas where the residual radioactivity exceeds the proposed criteria (minimal action), and (3) to clean up the former vehicle decontamination facility and around the former untreated waste outfall. Calculations based on actual measurements indicate that the annual dose at the location having the greatest residual radioactivity would be about $12 \%$ of the applicable guideline. Most doses are much sinaller than that. No environmental impacts are associated with either the no-action or minimal action alternatives. The impact associated with the cleanup alternative is very small. The preferred alternative is to clean up the areas around the former vehicle decontamination facility and the untreated waste outfall. This course of action is recommended not because of any real danger associated with the residual radioactivity, but rather because the cleanup operation is a minor effort and would conform with the ALARA (as low as reasonably achievable) philosophy.

\subsection{INTRODUCTION AND BACKGROUND}

1.1 The FUSRAP Program

In 1976, the Energy Research and Development Administration (ERDA) identified Acid/Pueblo Canyon as one of the locations to be re-evaluated 
Umbler t.hr Inrmerly Ut,ilized Sites Remedial Action Program (FUSRAP). The area r.m.idrerul in Acid/Pueblo Canyon consists of the former treatment plant site, thr former vehicle decontamination facility, the treated and untreated waste 1)irharye: rutfalls, and the Acid/Pueblo Canyon system into which the outfall rifluerits passed. The treatment plant site and vehicle decontamination fucility were designated as TA-45.

The locations identified in the FUSRAP program were to be resurveyed for residual radioactivity using modern instrument ation and analytical methods. The resurveys are the bases for determining whether further remedial action is necessary. The Acid/Pueblo Canyon resurvey was performed by the Los Alamos National Laboratory under contract to ERDA and, subsequently, the Department of Energy (DOE).

The results of the survey indicated subsurface residual radioactivity at the old treatment plant site and along the path of the untreated waste line. Surface residual radioactivity was found at the former vehicle decontamination facility, in the area of the untreated waste line outfall, on the cliff face where the treated wastes were discharged, and along the length of Acid Canyon. Residual radioactivity also was found in the sedinents and banks of the stream channels in Pueblo and Los Alamos Canyons. It consists primarily of $239 / 240 \mathrm{pu}$, although detectable quantities of $238 \mathrm{pu}, 24 \mathrm{l} u$, ${ }^{24} \mathrm{Am},{ }^{9} \mathrm{Sr},{ }^{13} \mathrm{Cs}$ and uranium also are present:

Because of this residual radioactivity, a set of alternatives for remedial action for Acid/Pueblo Canyon was identified. An engineering evaluation of the proposed alternatives was prepared by Ford, Bacon \& Davis Ut ah in a separate report. ${ }^{2}$ This report describes the environment al impacts associated with the proposed alternatives for the former TA-45 site, Acid Canyon, and middle Pueblo Canyon. Alternatives for lower Pueblo Canyon and lower Los Alamos Canyon will be considered in a separate report.

\subsection{Preferred Alternative}

The range of alternatives being considered for TA-45/Acid/Middle Pueblo Canyon includes no action, minimal action, and remedial action. The minimal action alternative requires fencing off an area encompassing the former vehicle decontamination facility and the untreated waste line outfall. These are the primary areas where surface residual radioactivity exceeds the proposed cleanup criteria. The remedial action alternative involves removal of surface residual radioactivity exceeding the proposed criteria.

The preferred alternative for TA-45/Acid/Middle Pueblo Canyon is remedial action. The potential radiological dose resulting from surface residual radioactivity at the former vehicle decontamination facility and the untreated waste line outfall is, under the worst conditions, only a small fraction of the applicable Radiation Protection Standards (RPS). However, 
these sites are readily accessible, and, thus, they should be cleaned up to conform to the ALARA (as low as reasonably achievable) philosophy. Remedial action at these cites will prevent further transport of radionuclides into the Acid/Pueblo/Los Alamos Canyon system. This alternative turns out to be less expensive than fencing the area to limit access. Costs of future surveillance and maintenance of fences in the extremely rugged terrain make the fencing alternative unacceptable. Two small areas of above-criteria residual radioactivity would not be treated under this alternative because they are located farther down in the canyon in an area that is rather inaccessible to either people or cleanup equipment.

\subsection{ACID/PUEBLO CANYON}

\subsection{Suminary History and Description}

2.1.1 Description. Los Alamos County is located in northcentral New Mexico, about $100 \mathrm{~km} \mathrm{NNE}$ of Albuquerque and $40 \mathrm{~km} \mathrm{NW}$ of Santa Fe by air, as shown in Fig. 1. Acid Canyon is a small tributary near the head of Pueblo Canyon, which is one of many canyons cut into the Pajarito Plateau (Fig. 2). Acid/Middle Pueblo Canyon is located within the tcwnsite of Los Alamos at T19N, R6E, Section 9. Figure 3 shows the location of the canyon system and the former TA-45 radioactive waste treatment $\mathrm{plant}$ site relative to surrounding features in the Los $A$ amos townsite. Access to the former waste treatment plant site is from Canyon Road, which runs just to the south of it.

\subsubsection{History of Site. 1}

2.1.2.1 Operations and Waste Disposal. The radioactive liquid wastes handled at the TA-45 site resulted from work started in 1943 as part of Project $Y$ of the US Army's secret Manhattan Engineer District. The purpose of the project was to develop a nuclear fission weapon. Los Alamos was selected in November, 1942, as the site for Project Y. The War Department acquired the LoS Alamos Ranch School, which consisted of 54 buildings and about $14.6 \mathrm{~km}^{2}$ of school and other private ho' lings. About $186 \mathrm{~km}^{2}$ of additional land were acquired from other govf nment agencies. The total 1 and area included essentially all of what is pre it-day Los Alamos County. The first construction contract was let in December, 1942, and in January, 1943, the University of California assumed responsibility for operating the Laboratory. The first technical facilities, known as the Main Technical Area or $T A-1$, were constructed on about $0.16 \mathrm{~km}^{2}$ near the then-existing Ranch School facilities around Ashley Pond and along part of the north rim of Los Alamos Canyon. Buildinijs, in which general laboratory or process chemistry and radiochemistry wastes were produced, were served by industrial waste lines known as acid sewers. Ultimately, all such industrial wastes flowed 


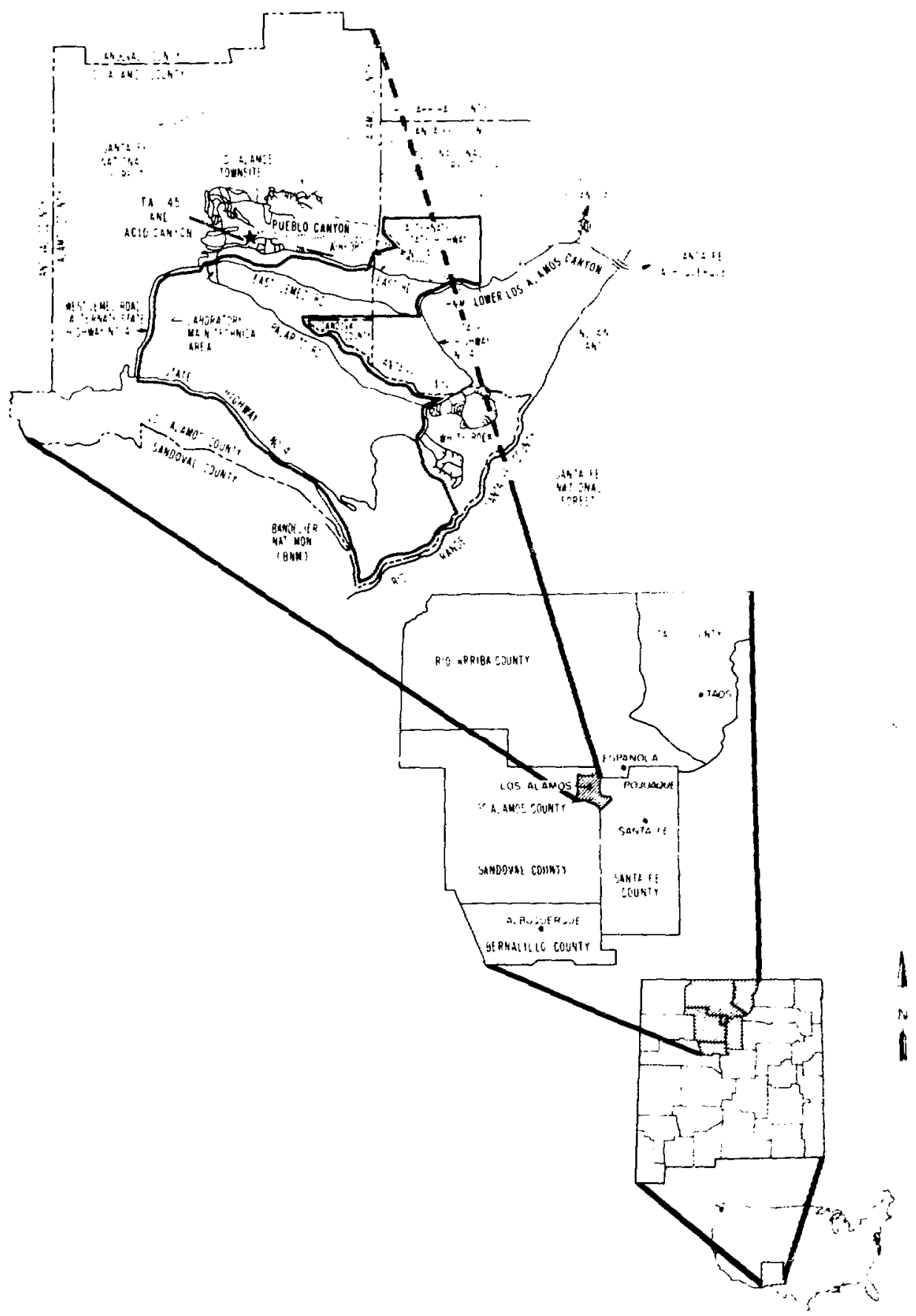

Fig. 1. Regional location of study area. 


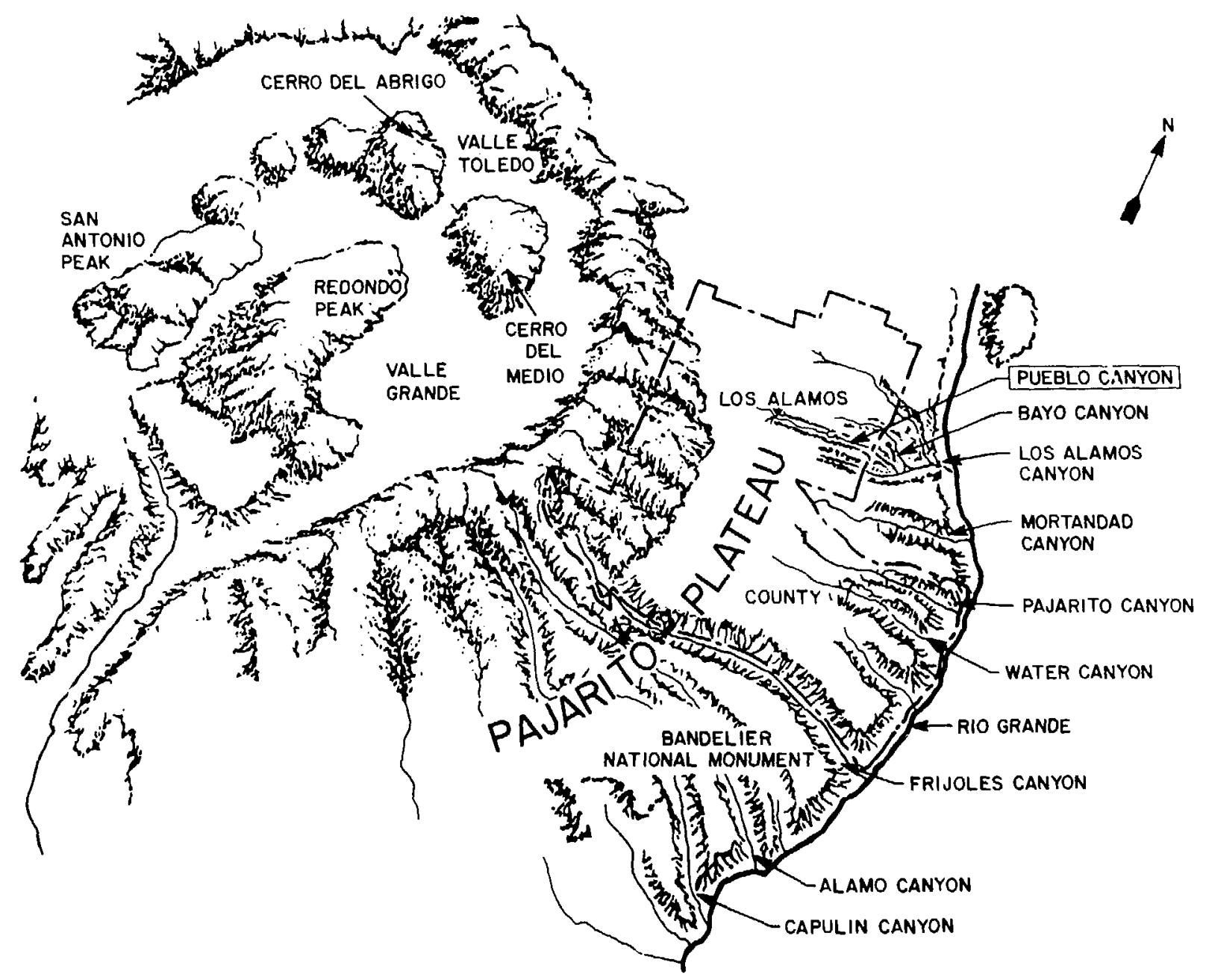

Fig. 2. Physiographic setting of Los Alamos County. 


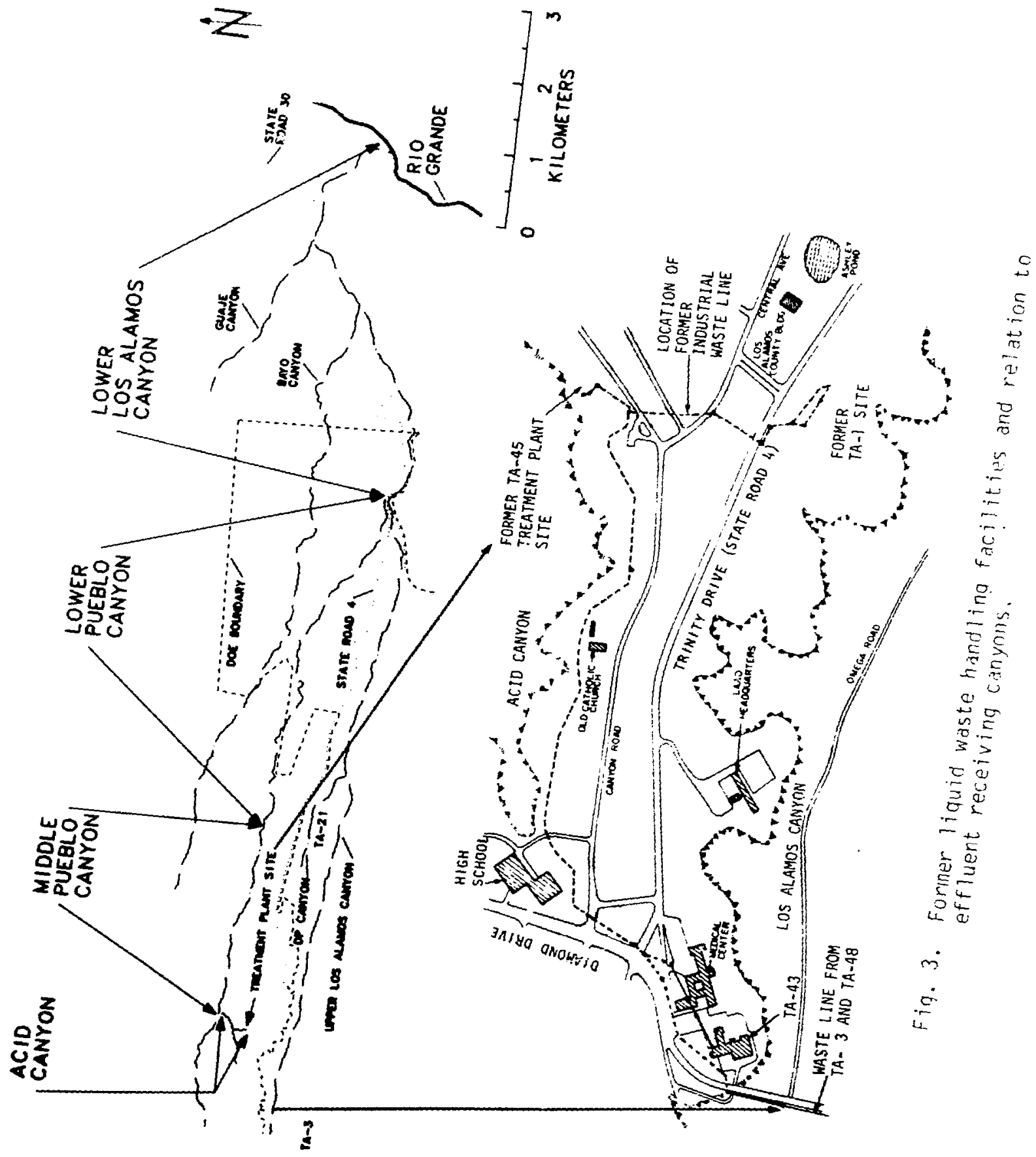


into a main acid sewer that extended generally north to a discharge point at the edge of Acid Canyon (Figs. 3 and 4 ).

The untreated liquid waste discharge started in late 1943 or early 1944 and continued through Apri1, 1951. These effluents contained a variety of radioactive isotopes from research and processing operations associated with nuclear weapons development. No detailed analyses are available, but the radioisotopes of interest included tritium and isotopes of strontium, cesium, uranium, plutonium, and americium. From limited data, estimates were made of the $\mathrm{me}^{\circ}$ isotopes released in the untreated effluents. These estimates are sunmar1: in Table I. The plutonium concentrations in these releases must have averayiu about $1000 \mathrm{pCi} / \ell$ with maximum concentrations of about 10000 $\mathrm{pCi} / \ell$.

In 1948, a joint effort was started between the Laboratory and the US Public Health Service to develop a method for removing plutonium and other radionuclides from radioactive liquid waste. Bench scale experiments showed that coriventional physicochemical water treatment methods could be modified for treatment of radioactive waste. By June, 1951, a treatment plant, identified as TA-45, had been designed and constructed. It began processing radioactive and other laboratory wastes by a flocculation-sedimentation-filtration process. The final effluent, containing about $1 \%$ of the influent plutonium concentration, was sampled before release into Acid Canyon. The $239 \mathrm{pu}$ concentrations in the effluent ranged from about 20 to $150 \mathrm{pCi} / \&$ while the plant was in operation. Summary data on the radioactivity content of the released effluent are in Table I. The plant typically removed çs. to $99 \%$ of the plutonium in the influent. Thus, a total of about $0.34 \mathrm{~g}$ of plutonium was released in treated effluent during the $14 \mathrm{yr}$ that the plant was in operation, compared to an estimated $1.9 \mathrm{~g}$ released in untreated waste during the previous 3 $y r$. These mass values show the small quantity of plutonium that ended up in liquid waste streams during the early years of Los Alamos National Laboratory operation.

From startup until mid-1953, the TA-45 plant treated liquid wastes only from the original Main Technical Area, TA-1. Starting in June, 1953, additional radioactive liquid wastes were piped to TA-45 from the new laboratory complex (TA-3) south of Los Alamos Canyon. This complex included the Chemistry and Metallurgical Research building where plutonium research was conducted. In September, 1953, liquid wastes from the Health Research Laboratory (TA-43) were added to the system. Initially, the TA-3 waste was very dilute, and levels were monitored to determine whether treatment was required to maintain the 2-wk effluent average from TA-45 below 330 disintegrations/min/l, the level adopted as the administrative levol for effluent release from TA-45. If treatment was not required to meet the criteria, the TA-3 waste was discharged untreated to Acid Canyon. By December, 1953, only about $30 \%$ of the TA-3 waste was released untreated. In 1958, 1iquid wastes from a new radiochemistry facility (TA-48) were added to the line coming from 


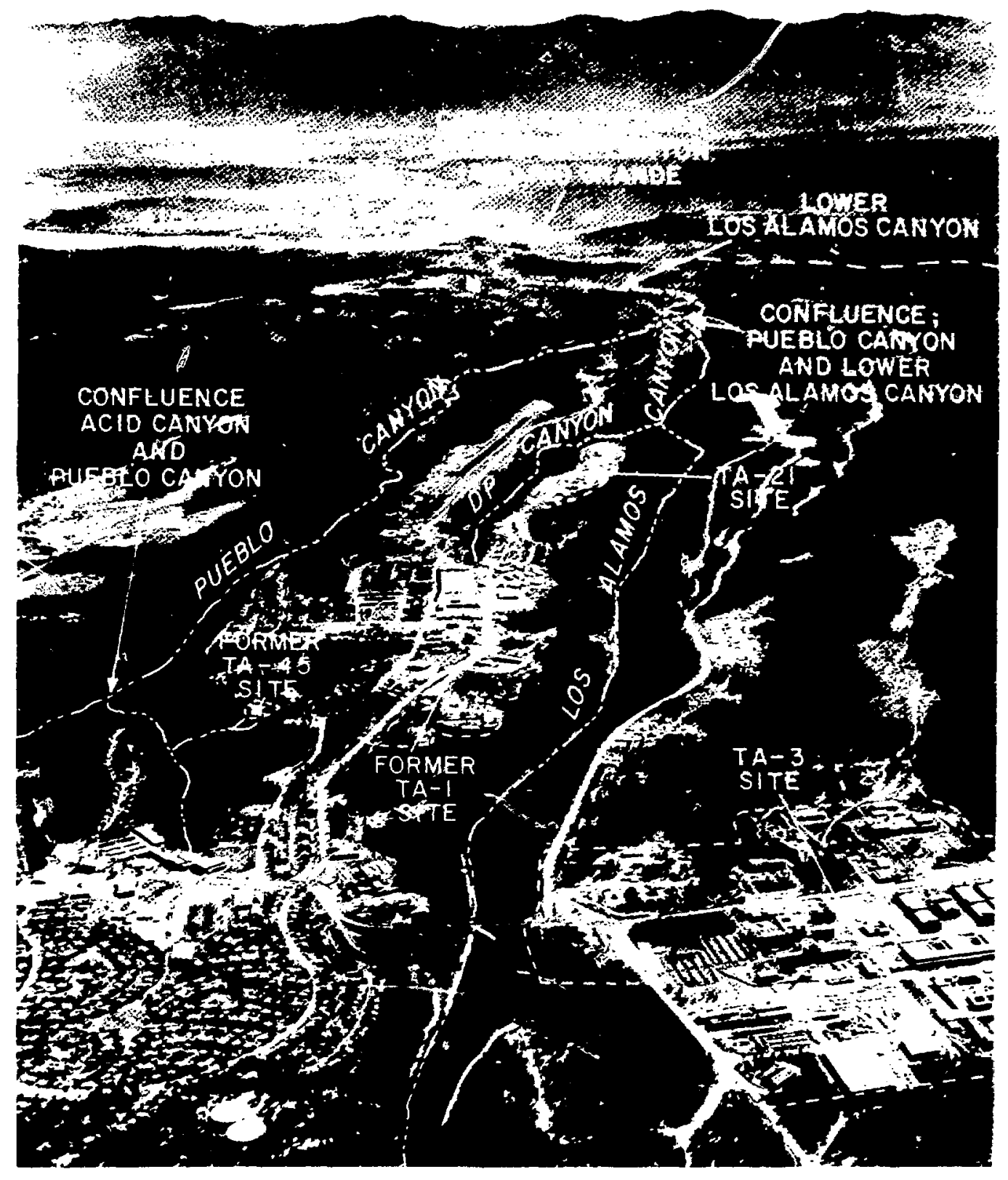

Fig. 4. Aerial view of LoS Alamos and study area looking east. 
TABLE I

RADIOACTIVITY CONTENT OF EFFLUENTS RELEASED TO ACID CANYONa

Untreated Effluents, 1943 through Aprîl 1951

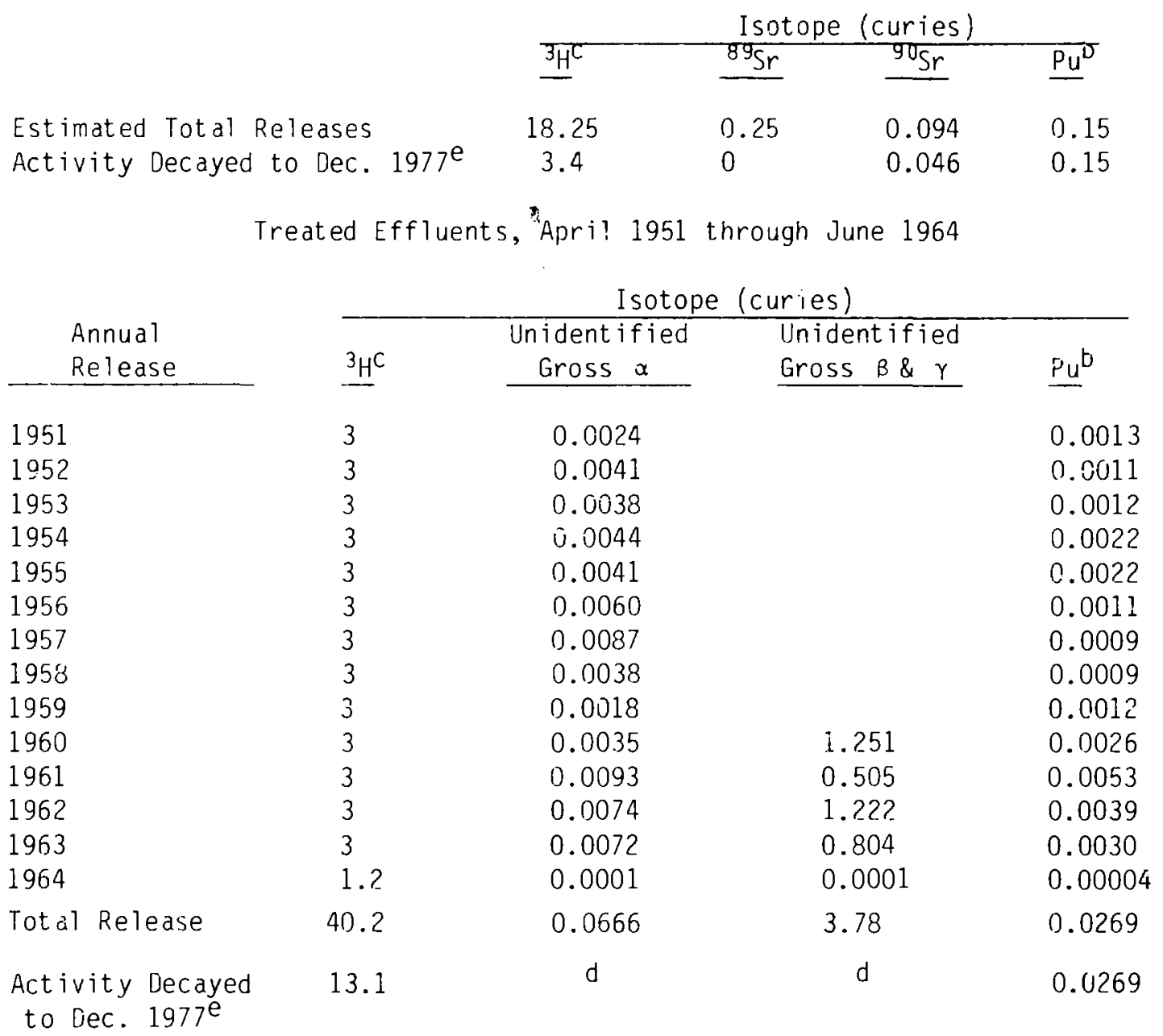

${ }^{2}$ Measured and estimated data as compiled for and summarized in the US DOE Onsite Discharge Information System (001S).

b Total plutonium, predominately $239 \mathrm{Pu}$, but includes small amounts of other isotopes. Reported in ODIS as $239 \mathrm{pu}$.

$\mathrm{C}_{\mathrm{A}} 11$ tritium values estimated.

$\mathrm{d}_{\text {No }}$ estimate of decayed value made because data on isotopic mixtures are not available. The gross $\alpha$ is assumed to be predominantly plutonium and uranium; therefore, little decay would have occurred. If the gross $\beta$ and $\gamma$ are assumed to be 1 argely ${ }^{90} \mathrm{Sr}$ and ${ }^{1{ }^{7}} \mathrm{Cs}$, then decayed value would be about $70 \%$ of total released.

Eecay based on year of release and appropriate half-life. 
TA-3. The wastes from thi; facility included primarily fission products and are reflected in the higher gross beta anu gamia content of the TA-45 effluents shown in Table I for 1960 through 1963.

In July, 1963, wastes from TA-3 and TA-48 were redirected to a new Central Waste Treatment Plant (TA-50) located south of Los Al amos Canyon, which is still within the present Los Alamos National Laboratory site. Liquid wastes from TA-43 were redirected to the sanitary sewer because only small quantities of very low concentration wastes were generated by that time. Subsequently, only liquid wastes from TA-1 were processed at TA-45 unt il it. ceased operation near the end of May, 1964. Somc untreated low level liquid. wastes containing fission products from decomissioning the Sigma Building at TA-1 were released until June, 1964. After this time, no further effluents were released into Acid Canyon.

2.1.2.2 Decontamination and Decommissioning. Tecontamination and decommissioning of the TA-45 liquid waste treatinent plant beyan in october, 1966. All contaminated equipment, plumbing, and removable fixtures were takei to solid radioactive waste burial areas still located within the current Los Alamos National Laboratory site. The structures for the waste treatment plant (TA-45-2) and the vehicle decontamination facility (TA-45-1) were demolished and all debris removed to the disposal areas. Buried waste lines, manholes, and a significant amount of contaminated soil in the vicinity of the decontamination structure were dug out and the debris transported to the solid radioactive waste disposal area. A total of about 516 dump-truck loads of debris were removed during these operations. During the same time, decontamination of portions of Acid Canyon was undertaken. Contaminated tuff was removed from the cliff face where the effluent had flowed. Men using $j a c k-$ hammers and axes were suspended over the cliff edqe nn ropes with safety harnesses to remove contaminated rock. The debris was loaded into dump trucks at the bottom of the cliff. Some contaminated rock, soil, and sedinent also were removed from the canyon flour. A total of about 94 dump-truck loads of debris were removed from Acid Canyon. The operation was suspended in January, 1967, because of cold weather. In the spring of 1967, additional decontamination was undertaken, including other portions of buried waste lines in the TA-4o area, more contaminated rock, and the flow-measuring weir from Acid Canyon. By July, 1967, the TA-45 site and Acid Canyon were considered sufficiently free of contamination to allow unrestricted access and removal of signs designating it as a contaminated area. Fernaining residual radioactivity at that time was documented to be less than 500 counts/min of alpha activity (as measured by a portable air proportional aipina detector) in some generally inaccessible spots and was not considered iu be a health hazard.

\subsubsection{Land Ownership. Pursuant to the Community Disposal Act,} the Atomic Energy Commission (AEC) transferred ownership of substantial portions of the LoS Alamos townsite to the County of LoS Alamos by quitclaim deed on July 1, 1967. This transfer included the former TA-45 site, Acid 
Canyon, and the portion of iuelo? Canyn urcurpassing the channel from Acid Canyon eastward ta a poirt abrut 1100 m west of the Los Alamos-Santa Fe County line. This traster was suhject to a reserved easement for cont inued access to an! maintenduce of sampling loc dtions and test wells in and ad-

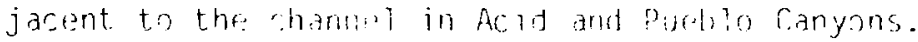

\subsection{Need for Actiori}

2.?.1 Potential lose Evaluation and lnterpretation. The significance of

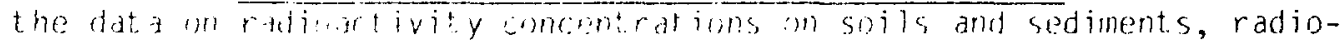
activity or airlurne pallicaldon, an external penetrating radiation may be evaluater in tran of the deser, tha can be receivad by peuple exposed to the

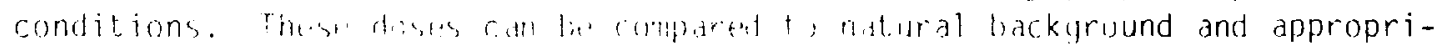

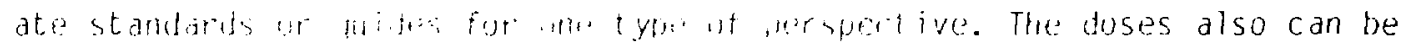
used to estimate $r i 4 k:$ or prohdhilitiex uf medth affects to an individual, providine anotho i ype ij perepertive illor: readily compared to other risks encountered. "ins wetion sumbarizs the analysis of potential doses and

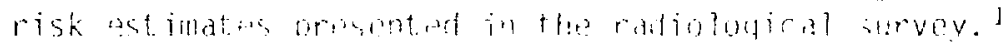

2.:2.1 bases of liose t ct imates ard Comparisons. Doses were calcu1 ated for varius, athways that could result in the inha? at ion or ingestion of radinactivity. Tirt calculations were based on theoretical models or $f a c-$ tors from indarid references and health physics literature, as detailed in the radiologica! survey. ${ }^{1}$ The doses are expressed in fractions of rems, where

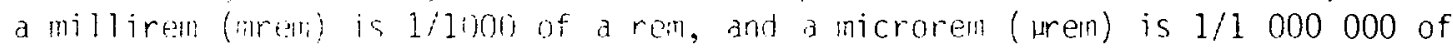
a rem. They are generally expressed as dose rates; that is, the radiation dose received in a jarticular time interval. The rem is a unit that permits direct comparison of toces from different sources, such as $x$ rays, gamma rays, and alpha particlos. It accounts for the differences in biological effects from the entary absished from different radiations and isotope distributions. These doses can be compared to the DOE RPS, which are expressed as permissible cose or dose commitinent above natural background radiation and medical axposures. First year doses represent the dose received during the first yoar that a qiven radiodctive isotope is ingested or inhaled. Because mot of the isotopes of concern in this study are retained in various organs in the body for more than a year, 50-yr dose commitments also were calculated. The $50-y$ dose commitment represents the total dose that would be accumulated in the body or specific critical organs over a 50-yr period from ingestion or inhalation Juring the first year. (Alternatively, the numerical values can be interpreted to represent the annual dose $r a t e$ during the 5i)th yr given continuous exposure over all $50 \mathrm{yr}$.) The 50 -yr commitments always are as large or larger than first year doses. In this summary, only thes 50-yr commitinents are compared to the standards.

Conceptually, this ayrees with recomnendations of the International Comisision on Radiuloqical Protection (ICRP) that, for regulatory purposes, in effect charge the entire dose comitment against the year in which 
exposure occurs. ${ }^{3}$ Use of the $50-y r$ dose comnitment also permits estimates of risk over a lifetime from the given exposure and simplifies comparisons between different exposure situations. The dose commitments were calculated using published factors from references currently used in requlation. ${ }^{4,5}$

\subsubsection{Potential Doses Inder Present Conditions. Given present} conditions of land use and the residual radinactivity in the affectod areas, there are two basic groups (not mutually exclusive) of the public to be considered. One group is the normal residential and working population in Los Alamos County. Measurements of airborne radiuactivity and external penetrat. ing radiation over many years as part of the Lus Alam National Lahoratury routine environmental monitoring progran lnat to the com lusion that thic, group is not receiving increments of radiation exponare at ribulable to the residual radioactivity. The second group includes, those wha or cupy the ranyon areas for varying periods of time. The occasional wsers--hikers, nirkniskers, horseback riders, and others-spend only a sma!l fractim of anv qiven year in the affected areas,

The potential for exposure is more-or-less linearly dependent on the amount of time spent in one of the affected areas. For this summary, no attempt. was made to develop assumptions of the fractions of time spent by any given person or group in various areas. The maximum likely doses for continuous occupancy throughout a year are tabulated in Table Iy for each canyon segment. These estimates should overstate average annue? doses by varying amounts, even for continuous cccupancy, because of the assumptions used for the analysis and interpretation of data, as detailed in the radiological survey. 1 To give two examples: (1) the calculated external penetrating radiation doses are based on the highest avwaracs of soil concentrations in a given segment, even though they persist over on ?y smai fractions of the total area and are close to the channels, and ?) actuai measurements of airborne radioactivity concentrations in Puebl: Canyon suggest that the theoretically estimated resuspension of soils containing residual radioactivity probably overstates actual average levels by a factor of about 10 .

In the canyon areas, the calculated external penetrating radiation whole-body dose for 1-yr occupancy ranges from less than 0.1 mrem in Puetir, Canyon to about 10 inrem in Acid Canyon. (All of the external penetrating radiation dose is received in the year of exposure, but for risk estimation that dose also $c$ an be considered to be the entire dose commitment from that exposure.) The calculated 50-yr dose commitments from inhalation of resuspended dust during 1 -yr range from less than 0.001 to about 0.05 nrem to the whole body, from about 0.001 to about $2.1 \mathrm{mrem}$ to bone, and from about 0.004 to about $0.11 \mathrm{mrem}$ to lung. None of these are more than about $2 \%$ of the appropriate DOE RPS, and most are less than $0.5 \%$. 
MAXIMUM LIKELY INCREMENTS OF RISK BASED ON EXPOSURE ATTRIBUTABLE TO RESIDUAL RADIOACTIVITY IN ACID AND MIDOLE PUEBLO CANYONS ${ }^{a}$

(Increased Probability Based
$\frac{\text { Incremental Risk }}{\text { on 50-yr Dose Commitment) }}$
Locall
Cancer $\begin{gathered}\text { Bone } \\ \text { Mortality Lancer } \quad \text { Cancer }\end{gathered}$

\begin{tabular}{c} 
Incremental Dose Commitment \\
$\begin{array}{c}\text { (mrem in } 50 \mathrm{yr} \\
\text { from Given Exposure) }\end{array}$ \\
$\begin{array}{c}\text { External } \\
\text { Whole } \\
\text { Body }\end{array}$ \\
\hline
\end{tabular}

$1-y r$ Occupancy

Acid Canyon

Middle Pueblo

Canyon

Treatment $P$ lant

site
$9.7 \times 10^{-7}$

$1.1 \times 10^{-8} 2.2 \times 10^{-9}$

$1.2 \times 10^{-8}$

$3.6 \times 10^{-9} 7.6 \times 10^{-10}$

0.1

60
$6.0 \times 10^{-6}$
9.6
0.053

0.018

0.73

2.1

0.11

a All calculations based on 1978 conditions.

b probabilities are expressed in exponential notation; they can be converted to expressions of chance by taking the numerical value in front of the multiplication sign ( $x$ ) as "chances" and writing a one (1) followed by the number of zeros given in the exponent. For example, $9.7 \times 10^{-7}$ becomes 9.7 chances in 10000000 . 


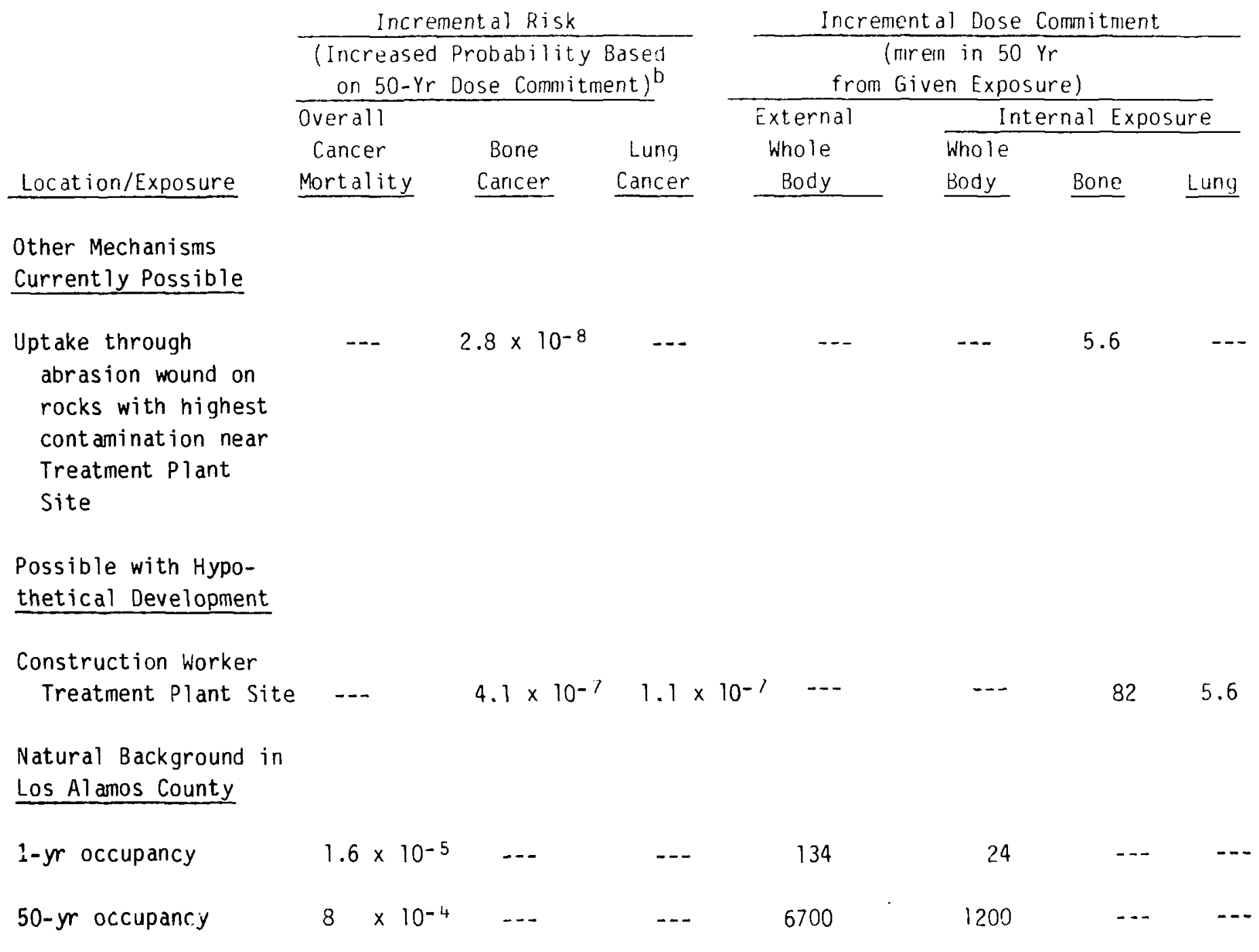


TABLE II (cont)

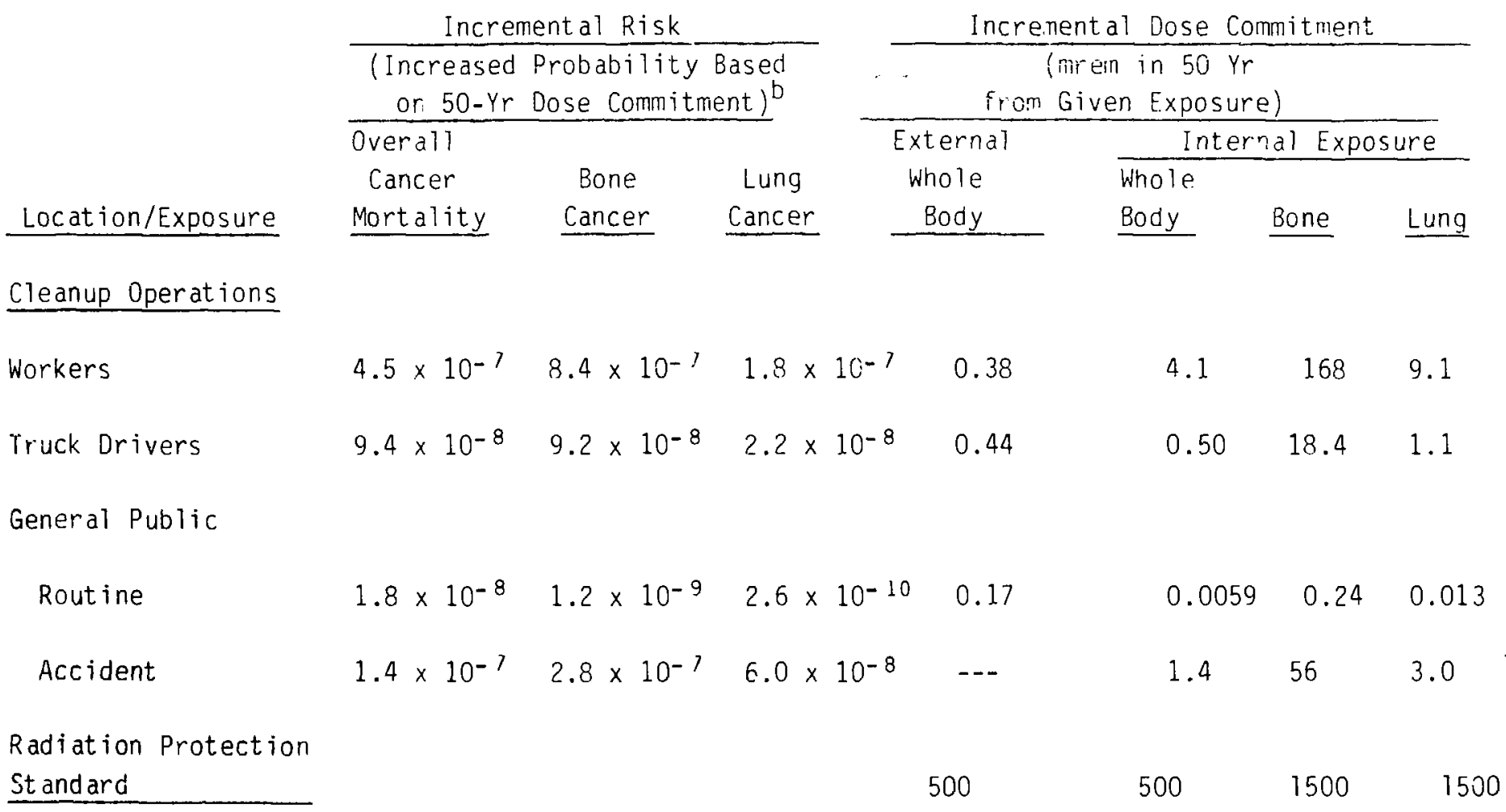


Several other mechanisms of exposure that might affect a few individuals were considered. The estimated doses from these pathways also are presented in Table II. At the site of the former treatment plant, there are some relatively small areas where external penetrating radiation is above background. The unlikely possibility of continuous occupancy of that location is estimated to result in annual exposure of about 60 mrem absve natural background (12\% DOE RPS, $40 \%$ of natural background). A person who wounds himself on a rock in the former untreated waste outfall drainage may sustain an uptake of residual radioactivity through an abrasion wound from the rock surfaces with the highest concentrations. Contact with the highest concentrations is estimated to result in a 50-yr dose commitment of about $5.6 \mathrm{mrem}$ to bone $10.3 \%$ of DOE RPS, $3.7 \%$ of natural background).

2.2.1.3 Potential Doses Under Future Conditions. Several types of changes could occur in the future that would alter potential exposures. One is the possibility of residential development of some of the areas, although such development is not presently being considered (Sec. 4.1.2). Doses to future residents are shown in Table II, where they are seen to be, at worst, about $12 \%$ of the applicable RPS.

An additional pathway associated with residential development is the inhalation of dust by construction workers. Estimates of maximum likely doses from these activities also are summarized in Table II. Conservative assumptions of nigh breathing $r$ ates, extremely dusty conditions, and the highest average soil concentrations for the stratum should overstate these estimates. Another consideration is that the construction worker dose would likely be a one-time occurrence. The maximum doses for construction workers are about $6 \%$ of DOE RPS or $60 \%$ of natural background.

Another change that could occur is the alteration of the current occurrence and distribution patterns of residual radioactivity by natural processes. With time, some isotopes will decrease in concentration because of radioactive decay, and some isotopes will increase as the result of ingrowth of radioactive daughter products. In the case of transuranics, both processes are involved. The net effect of the decay of $238 \mathrm{pu}$ and ${ }^{24} \mathrm{lpu}$ and the ingrowth of ${ }^{24}{ }^{\mathrm{Am}}$ are calculated and accounted for in the effect on total dose rates due to transuranics inhaled on resuspended dust. The conclusion is that the differences in potential doses in the future, at the time of inaximum ingrowth of $24 \mathrm{Am}$ (about year 2050), would be, at most, $4 \%$ higher (whole body, 1st-yr dose) and 4\% lower (bone, 1st-year dose) than for current conditions. These are much smaller differences than already implicit in the uncertainties of the calculations. Portions of the doses attributable to the fission products strontium and cesium, which have half-lives of about $30 \mathrm{yr}$, will continuously decline by a factor of about 2 every $30 \mathrm{yr}$. Concentrations of ${ }^{137} \mathrm{Cs}$ were largely responsible for the calculated external penetrating doses in the vicinity of the former waste treatment plant site. 
Redistribution of the sediments carrying residual radioactivity by hydrologic transport is another likely mechanism of change. Moderate flows in Pueblo Canyon, such as those associated with snowmelt runoff and thunderstorm peaking events of the magnitude that have evidently occurred in the last 10 to $20 \mathrm{yr}$, would be expected to continue the patterns of change in distribution as detailed in the radiological survey. ${ }^{1}$

\subsubsection{Potential Doses Associated with Cleanup. Radiation doses} resulting from removal of residual radioactivity from the former treatment plant site were evaluated for cleanup workers, truck drivers hauling the material to the waste disposal site, and the general public. Both routine and accident situations were cnnsidered. Resulting doses were then compared with the appropriate RPS. ${ }^{6}$ A discussion of the dose calculation procedures anu assumptions is presented in Appendix $A$.

The calculated doses were used as the basis for estimating health risks associated with remedial action at the former plant site. The associated risks are discussed in Sec. 2.2.2.2.

Ford, Bacon, and Davis Utah estimated that 10 to 12 days would be required for cleanup and restoration of the site. ${ }^{2}$ Contact with soil containing residual radioactivity would require about 7 days: 2 days for site preparation and 5 days for excavation and hauling soil. The doses presented below are calculated assuming $56 \mathrm{~h}$ ( 7 days) of exposure to this material.

\subsection{Doses to Cleanup Workers. Radiation protection} personnel would supervise cleanup operations to ensure that soil containing residual radioactivity is kept wet so that dust generated by heavy machinery and wind is minimized. Continuous air samplers would monitor airborne concentrations of radioactivity, which constitute the major pathway of exposure to the crew. Respiratory protection equipment would be used in all areas where there is any indication that above-background concentrations of local airborne radioactivity exists, as well as in areas having soil activity in the several $\mathrm{mCi}(1 \mathrm{mCi}=1000 \mathrm{pCi})$ per gram range. Nose swipes would be taken after each use of a respirator.

Members of the cleanup crew would be radiation workers. These workers carry personal radiation monitoring devices that record their exposure to external radiation. They undercu periodic bioassay monitoring, including urinalysis and chest counting, to confirm that radiation prevention measures are working effectively and to determine any incremental radiation dose. All personnel involved in the cleanup would wear protective clothing: coveralis, gloves, footwear, and head coverings.

Cleanup experience at other former technical areas 7,8 has shown operational control measures to be effective in keeping radiation exposures 
low. Personnel monitoring has shown that doses received by individuals irivolved in these operations are usually only a few per cent of the RPS for workers. Cleanup operations at Acid Canyon were evaluated on the basis of radiation exposures to personnel involved in similar cleanup operations carried out elsewhere at the Laboratory. The procedures followed in making these dose calculations are described in Appendix $A$. The maximum 50-yr dose commitment to a worker from inhalation of dust containir.g residual radioactivity is estimated to be 168 mrem to bone, the organ receiving the highest dose. The maximum whole-body dose resulting from exposure to above-background gamma radiation is $0.4 \mathrm{mrem}$. The total dose co bone is $169 \mathrm{mrem}, 2 \%$ of the RPS for bone dose to workers for a calendar quarter. ${ }^{6}$ The total whole-body dose is estimated to be $4.5 \mathrm{mrem}, 0.1 \%$ of the RPS for whole body for a calendar quarter. 6

These dose estimates do not include a standard respiratory protection factor of 100 due to the use of full-face masks. Full-face masks would be worn for that part of the project when soil with higher levels of residual radioactivity would be excavated. Use of respiratory protection equipment would lower the above dose estimates accordingly.

2.2.1.4.2 Doses tc Truck Drivers. Trucks would haul the estimated $230 \mathrm{~m}^{3}$ of soil containing residual radioactivity to the radioactive waste disposal site (TA-54) located on Laboratory property. Drivers would spend approximately $11 \%$ of their time at TA-45 in areas that might have above-background levels of airborne radioactivity. They would receive additional exposure to external penetrating radiation, which is emitted by their cargo, while traveling to the waste disposal site. Total exposure times were based on estimates that drivers would spend $16 \mathrm{~h}$ of the estimated $40 \mathrm{~h}$ (5 days) for excavation carrying a full load of soil to TA-54, $3 \mathrm{~h}$ at TA-54, another $16 \mathrm{~h}$ returning to the TA-45 site, and $5 \mathrm{~h}$ at the site. The maximum 50-yr dose commitment for drivers is estimated to be 19 mrem to bone, $0.2 \%$ of the RPS for workers (calendar quarter). The maximum whole-body dose is 0.94 mrem, $0.02 \%$ of the RPS for workers (calendar quarter) (see Appendix A).

2.2.1.4.3 Doses to the General Public. Radiation exposures to the general public from routine operations were evaluated using data from previous similar cleanup projects. Doses to the general public through exposure to external radiation as a result of cleanup would be negligible because of the small external radiation fields (the maximum external radiation field was measured to be $50 \%$ of the natural background radiation field), the limited area where these fields are present, and the short time that individuals would be exposed (Appendix A). Consequently, the principal exposure mechanism for the general public would be inhalation of dust generated by the cleanup activities. Environmental monitoring performed during similar cleanup projects found no gross alpha and gross beta concentrations in air that were significantly different fram concentrations measured by the 
environinental air sampling network. ${ }^{7,8}$ In one project, 233 pu concentrations in air samplers were occasionally found to be somewhat higher than those in control locations. ${ }^{7}$ The maximum $233 \mathrm{pu}$ concentration was $0.46 \mathrm{fCi} / \mathrm{m}^{3}(0.46 \times$ $1 \mathrm{C} .15 \mu \mathrm{Ci} / \mathrm{ml})$, which is $0.3 \%$ of the Radiation Concentration Guide for $239 \mathrm{Pu}$ in controlled areas. ${ }^{6}$

No significant doses are expected to result from the routine transportation of soil containing residual radioactivity to the radioactive waste discosal site. Truck loads will have covers to prevent any release of material during transportation, which will effectively eliminate the potential for inhalation of material blowing off the trucks. Doses from external radiation to those individuals monentarily near the truck are estinated to be less than 0.17 mrem, which is $0.03 \%$ of the RPS. 6

Using conservative assumptions, the maximum 50-yr dose commitment incurred by a nember of the public as a result of the cleanup is estimated to be 0.41 inrem to the bone, which is $0.03 \%$ of the RPS (Appendix A) for the general public.

Radiation doses to the general public as a result of a truck accident resulting in a spill of soil containing residual radioactivity in a popuiated area also were evaluated. If such an accident were to occur, measures would be taken inmediately to control the dusting from the soil. These would include keeping the soil covered before removal and wet during removal. The soil would be removed as quirkly as possible. The maximum 50-yr dose commitment to the general public resulting from a spill of soil having radionuclide concentrations typical of the more radioactive material to be handled during this project is $56 \mathrm{mrem}$ to the bone, $4 \%$ of the RPS for members of the public 6 (Appendix A).

\subsubsection{Health Risks from Acid/Pueblo Residual Radioactivity}

2.2.2.1 Risks from Existing Conditions. Estimates of radiological risks are presented in Table II. These risks were calculated using risk factors recommended by the ICRP. ${ }^{9}$ Multiplying an estimated dose and the appropriate risk factor yields an estimate of the probability of injury to an individual as a result of that exposure. The risk factors used are

For uniform whole body dose Cancer mortality

For specific organ doses

Lung cancer

Bone cancer

$1 \times 10^{-4}$ per rein whole body

$2 \times 10^{-5}$ per rem to lung

$5 \times 10^{-6}$ per rem to bone.

As an example, a whole-body dose of $10 \mathrm{mrem} / \mathrm{yr}\left(1 \times 10^{-2} \mathrm{rem} / \mathrm{yr}\right)$ is estimated to add a risk of cancer mortality to the exposed individual of $1 \times$ $10^{-6} / \mathrm{yr}$ of exposure, or 1 chance in $1000000 / \mathrm{yr}$ of exposure. 
Natural background radiation for people in the Los Alamos area consists of the external penetrating dose from cosmic and teirestrial scurces, cosmic neutron radiation, and self-irradiation from natural isotopes in the body. The several year averace for external penetrating radiation measured by a group of 12 perimeter stations, located mainly in the Los Alamos townsite, is about. $117 \mathrm{inrem} / \mathrm{yr}$. Cosmic neutrons contribute abcut $11 \mathrm{mrem} / \mathrm{yr}$, and average self-irradiation, largely from natural radioactive potassium ( $\left.40_{K}\right)$, is about $24 \mathrm{mrem} / \mathrm{yr}$. These give a combined dose of about $158 \mathrm{mrem} / \mathrm{yr}$. Because of variations in the terrestrial component with location and time of year, this value is probably valid to about $\pm 25 \%$ for most of the Los Alamos population. For purposes of comparison, a rounded value of $150 \mathrm{mrem} / \mathrm{yr}$ is used as typical natural background in ihe area. This can be interpreted, using the ICRP risk factors, to represent a contipibution to the risk of cancer mortality cf $1.5 \times$ $10^{-5}$ (15 chances in 1000000$)$ for each year of exposure, or $8 \times 10^{-4}$ (8 chances in 10000 ) in $50 \mathrm{yr}$ of exposure to natural backaround radiation. As perspective, estimates of the overall US population lifetine $r i s k$ of mortality fron cancer induced by all causes is currently ahout $0 . ?$ (2 chances in 10). 10

Another context for judiging the significance of risks associated with exposure to radiation, whether from natura? background or other sources, is comparison with risks from activities or hazards encountered in routine experience. Table III presents a sampling of risks for activities that may result in early mortality and annual risks of death from accidents or natural phenomena. The largest incremental risks from exposure to the residual radioactivity are about the same as the incrementai risk of a 1000-mile automobile trip; most are smailer than the annual risk of death from lightning. Radiation from various natural external and internal sources results in exact?y the same types of interactions with body tissues as those from so-called "manmade" radioactivity. Thus, the risks from a given dose are the same, regardless of the source.

2.2.2.2 Risks from Cleanup. Dose estimates from Sec. 2.2.1.4 and risk factors presented in Sec. 2.2.2.1 were used to calculate the incremental risk of cancer mortality resulting from radiation doses received during cleanup operations. The estimated risks are presented in Table II. The risks are calculated for cleanup workers, drivers, and the general public.

As can be seen in the table, the largest risk of injury fram radiation exposure would occur to the cleanup workers. The incremental lifetime risk of cancer mortality from bone cancer is $8.4 \times 10^{-4}$ ( 1 chance in 1200000 ). A1l other risks of cancer mortality to the drivers and the general public would be lower.

The risk estimates in Table II can be compared to those incurred from exposure to natural background radiation, as discussed in Sec. 2.2.2.1. The 


\section{TABLE II I}

\section{RISK COMPARISON DATA ${ }^{\mathrm{a}}$}

Individual Increased Chance of Death

Caused by Selected Activities ${ }^{a}$

Increase in Chance

Activity

Smoking 1 pack of cigarettes (cancer, heart disease) of Death

Drinking $1 / 2$ liter of wine (cirrhosis of the liver)

$1.5 \times 10^{-5}$

Chest $x$ ray in good hospital (cancer)

Travelling 10 miles by bicycle (accident)

$1 \times 10^{-6}$

Travelling 1000 miles by car (accident)

$1 \times 10^{-6}$

Travelling 3000 miles by jet (accident, cancer)

$1 \times 10^{-6}$

Eating 10 tablespoons of peanut butter (liver cancer)

$3 \times 10^{-6}$

Eating 10 charcoal broiled steaks (cancer)

$3.5 \times 10^{-6}$

$2 \times 10^{-1}$

$1 \times 10^{-1}$

IJS Average Individual Risk of Death in One Year Due to Selected Causes

Cause

Motor Vehicle Accident

Accidental Fall

Fires

Drowning

Air Travel

Electrocution

Lightning

Tornadoes

\section{Annual Risk of Death}

$2.5 \times 10^{-4}$

$1 \times 10^{-4}$

$4 \times 10^{-5}$

$3 \times 10^{-5}$

$1 \times 10^{-5}$

$6 \times 10^{-6}$

$5 \times 10^{-1}$

$4 \times 10^{-1}:$

US Population Lifetime Cancer Risk

Contracting Cancer from All Causes

0.25

Mortality from Cancer

0.20

a Taken from Ref. 1. 
lifetime risk of cancer mortality from a 1-yr exposure to background radiation is, $1.5 \times 10^{-5}$ (15 chances in 1000000$)$. During $56 \mathrm{~h}$ of cleanup work, the lifetime risk of cancer from natural background radiation work is $1 \mathrm{x}$ $10^{-1}$ (1 chance in 10000000$)$.

2.2.3 Criteria Upon Which Cleanup Action is Based. The proposed criteria for determination of cleanup action are shown in Table IV. These dat a are taken from Refs. 11, 12, and 13. The basis for these criteria is the determination of the soil level for each radioisotope that would result in an annual dose to any organ greater than $500 \mathrm{mrem}$. This deterinination is made hy andyzing various pathways of exposure and then calculating the proposed criteria based on the worst exposure. The derivation of the criteria also assumes that the residual radioactivity is near the soil surface. The 500 mrem/yr dose for any organ is based on recommendations of the National Council on Radiation Protection and Measurements for dose limits for lhe general public. 14

In evaluating the areas containing residual radioactivity to determine where cleanup might be necessary, Ford, Bacon \& Davis l't ah used the formula

$\frac{c_{1}}{M_{1}}+\frac{c_{2}}{M_{2}}+\ldots+\frac{c_{n}}{M_{n}}$,

where

$C_{1}, C_{2}, \ldots, C_{n}=$ concentration of radionuclides

and

$M_{1}, M_{2}, \ldots, M_{n}=$ working criteria for these radionuclides.

Using this formula, cleanup was determined to be necessary if

$$
\sum_{0}^{n} \mathrm{C}_{i} \geq 1,0 .
$$

However, the engineering evaluation notes that, in every area where cleanup was necessary, some single radionuclide exceeded its proposed criterion. In no case did the summation call for clesinp when all radionuclides were below their individual proposed criceria. ${ }^{2}$ 
TABLE IV

\begin{tabular}{|c|c|}
\hline Nuclide & Concentration $(\mathrm{pCi} / \mathrm{g})$ \\
\hline $241 \mathrm{Am}$ & 20 \\
\hline $239 \mathrm{pu}$ & 100 \\
\hline $238 \mathrm{pu}$ & 100 \\
\hline $238 \mathrm{~J} / 234 \mathrm{U}$ & 40 \\
\hline $232 \mathrm{Th}$ & 20 \\
\hline${ }^{230} \mathrm{Th}$ & 280 \\
\hline${ }^{228} \mathrm{Th}$ & 50 \\
\hline${ }^{13 /} \mathrm{Cs}$ & 80 \\
\hline $90 s r$ & 100 \\
\hline
\end{tabular}

2.3 Other Agencies Involved in Implementation of the Proposed Action

Middle Pueblo Canyon, Acid Canyon, and the former TA-45 site presently are owned by Los Alamos County. Therefore, interaction and cooperation are necessary among DOE, the County, and the organization undertaking the renedial action.

Other agencies that may be involved are the State Environmental Division regarding radiological matters, the US Fish and Wildlife Services regarding the penegrine falcons in Pueblo Canyon ( $\mathrm{Sec} .4 .6 .3 .2$ ), and the State Historic Preservation Organization regarding archaeological and other historic sites.

\subsection{ALTERNATIVES}

Five general FUSRAP alternatives are modified to produce a range of alternatives for a given site. Modification or elimination of alternatives is based on site-specific conditions. The five general alternatives are as follows.

(1) No action.

(2) Minimal action--Limit public exposure to radioactive sources.

(3) Stabilization/entombment--Cover contamination with clean soil or encapsulate it.

(4) Partial decontamination--Remove easily accessible or p.tentially active sources to prevent further contamination.

(5) Decontamination and restoration--Remove and rehabilitate all contaminated areas to make site available for mrestricted use. 
Using these alternatives and considering the conditions at TA-45/Acid/ middle Pueblo Canyon, Ford, Bacon \& Davis Ut ah proposed three working alternatives. 2 These alternatives are discussed in the following sections. A summary of the actions associated with each option and their respective advantages and disadvantages is presented in Table $V$.

\section{TABLE $V$}

ACTIONS, ADVANTAGES, AND DISADVANTAGES ASSOCIATEOI WITH ACIO/PUEB O CANYON ALTERNATIVES

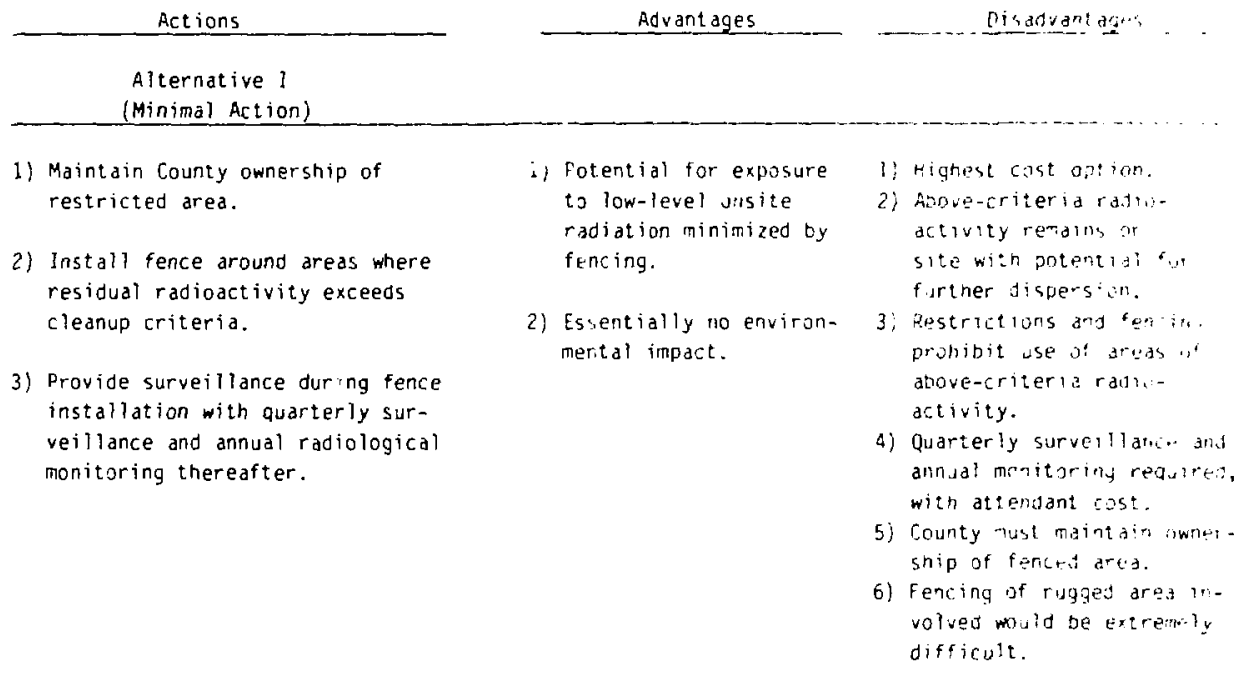

Alternative 11

(Remedial Action)

1) Remove residual radioactivity as necessary to meet working criteria.

2) Transport soil containing residud radiodctivity to solid waste disposal site (TA-54).

3) Provide radiological survey support and surveillance during cleanup.

4) Obtain DOE certification of cleanup site.
1) Radioactivity is reduced to working criteria levels.

2) No County ownership of site is required.

3) The site is available for unrestricted use.

4) No surveillance or monitoring is required after cleanup.

5) Permanent solution to problem.
1) Highest po:entiai for an accirent to accur.

2) Highest potential for short-term adverse enviromenta? impacts.

Alternative III

(No Action)

None
1) No cost.

2) No new environinental impacts.

3) Accomplished immediately.

4) No accident potential.
1) Low-level radiation exposure potential from onsite residual radioactivity is unchanged.

2) Above criteria residua? radioactivity remairs onsite with potential for further dispersion.

3) No restricted use. 


\subsection{Alternative I-Minimal Action}

In this alternative, a 0.45 -hertare area encompassing the former vehicle decontamination facility, the untreated waste effluent outfall, and a portion of upper Acid Canyon would be fenced to prevent access. This area encompasses all of the surface residual radioartivity known to exceed the proposed criteria. The exact location of the proposed fence is shown in Fig. 5. No other areas, iricluding the former treatment plant site, lower Acid Canyon, or

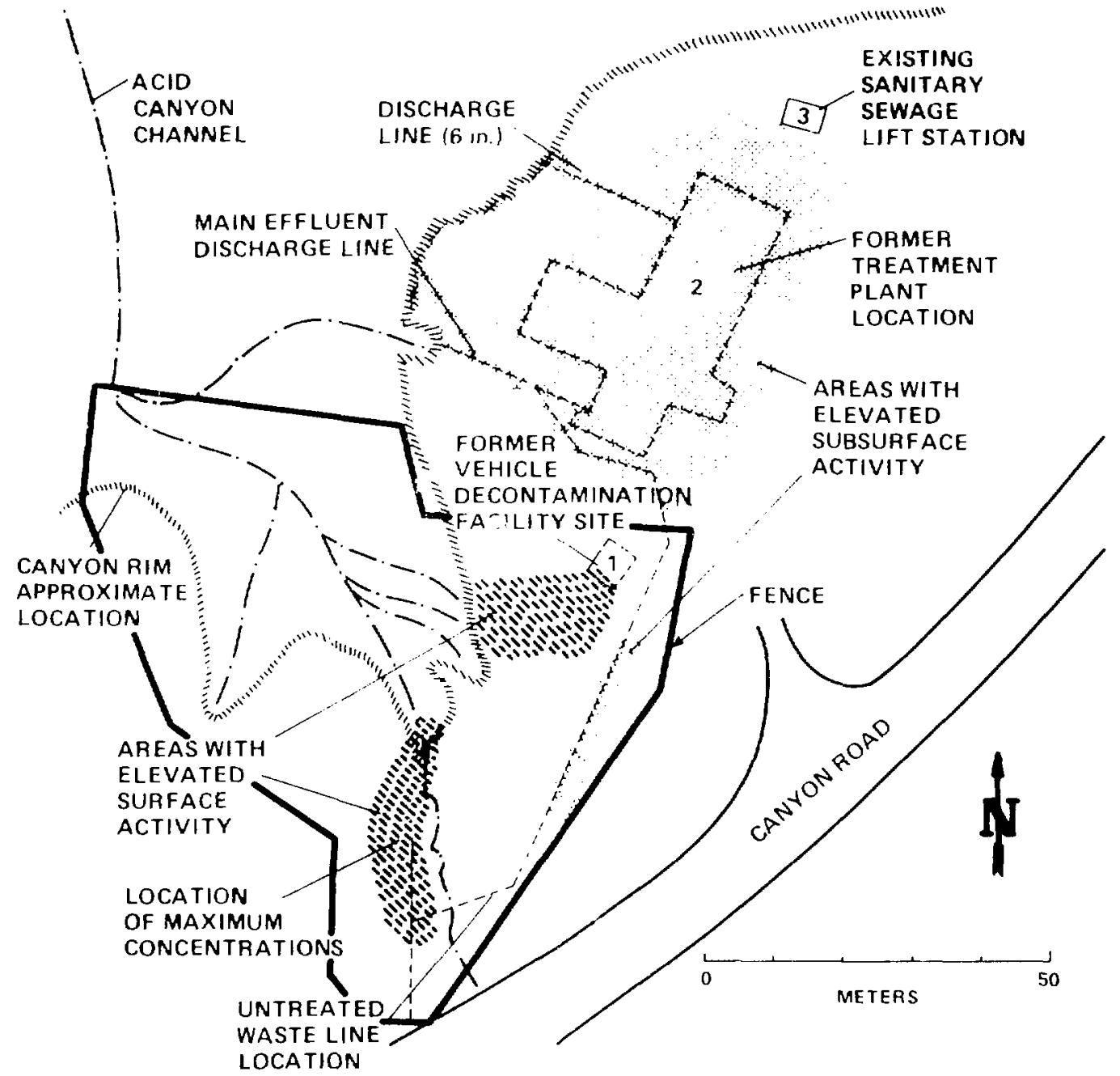

Fig. 5. Location of proposed fence and areas of residual radioactivity. 
Hidrlin Patb? Canyon, would be affected by this alternative because the r... idusl radinactivity in these areas does not excoed the proposed criteria. The unfenced areas would continue to be availahle for recreational furposes or other desired uses.

\subsection{Alternative II--Remedial Action (Preferrod Alternative)}

This alternative proposes cleanup of the riadily accessible areas of surface radioactivity exceeding the proposnd criteria at the site of the former vehicle decontaminaion facility and around the former untreated waste effluent outfall. The sinallor, more inaccessible sites of alove-criteria surface radioactivity, which are farther down in the more ruqued portion of Acid Canyon, would rot be addressed by this altermative.

The areas to be cleaned up are shown in Fig. 5. The soil in these areas would be removed to a depth of 30 to $45 \mathrm{~cm}$, which would result in a soil volume of about $230 \mathrm{~m}^{2}$. The excavated soil would tie hauled to the currert. Los Alamos National Laboratory radioactive solid waste disposal site (TA-54) for disposal.

\subsection{Alternative III--No Action}

In this alternative, no action would be taken at TA-45/Acid/middle Pueblo Canyon, which means that the property would remain unchanged and no costs would be incurred. This alternative represents current conditions as compared with the impacts that would result from implementation of other a)ternatives.

\subsection{AFFECTED ENVIRONMENT}

\subsection{Land lise}

4.1.1 ACid Canyon and the Former TA-45 Site. The former TA-45 site is located on the rim of Acid Canyon, which is a sinall tributary of Pueblo Canyon (Fig. 3). Most of Acid Canyon is rather inaccessible because of its steep-sided and generally rugged nature. Acid Canyon presently is accessible to the public for recreational use, but there is no evidence that such use occurs. The upper, more accessible part of Acid Canyon and former TA-45 site consitute an area of 1 to 2 hectares. This 1 and is owned by Los Alamos County. Part of it is flat and conceivably could be built upon, although there are no immediate plans to do so. The County presently is using the former TA-45 site as a landfill. Figure 6 shows some of the debris located on the former TA-45 site. This type of debris is interspersed throughout the 1 andfill. Use of this site for construction is unlikely both because of the debris and because the uncompacted fill, which is present to a depth of 4 to $6 \mathrm{~m}$ would make a poor foundation. 


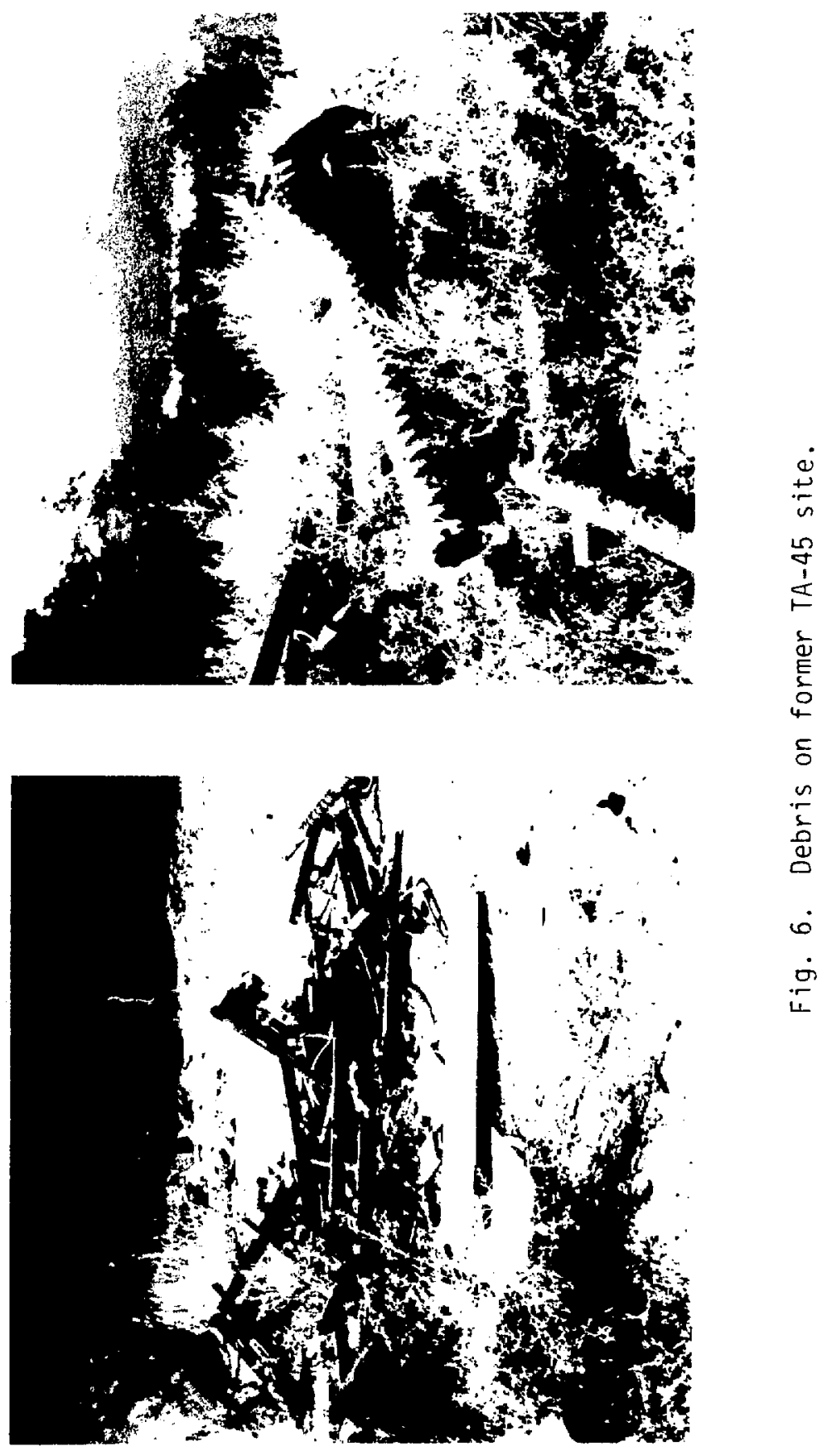


4.1.2 Middle Pueblo Canyon. This portion of Pueblo Canyon is narrow and steep sided. It is bordered on the north by North Mesa and on the south by the Los Alamos townsite. Some residential housing exists along the southern edge of North Mesa. The northern part of North Mesa is the location of the rodeo grounds and hoise stables.

Although lower Pueblo Canyon, which is relatively broad and $f 1$ at, has some potential for residential development, the middle section of the canyon is too narrow and steep sided for this use. The present primary use of middle Pueblo Canyon is for recreational purposes, and the long-range use plan of the county calls for its retention as a recreational area. 15

A dirt road provides access to lower and middle Pueblo Canyon. This road leaves State Road 4 just west of the junction of Pueblo and Los Alamos Canyons, proceeds across DOE property in lower Pueblo Canyon, through iniddle Pueblo Canyon, and leaves the canyon to the north at about the junction of Acid and Pueblo Canyons. The upper portion of this road is rough and probably accessible only by four-wheel drive vehicles. Also, a County sewage line runs down the canyon from residential areas near the head of the canyon to the sewage treatment plant in lower Pueblo Canyon. Recently, a new sewage line running along the stream channel was placed in the canyon. Its installation caused considerable disturbance of the radioactivity in the sediments.

\subsubsection{TA-54. Soil containing residual radioactivity would be removed} from Acid Canyon and the former vehicle decontamination site and would be taken for disposal to TA-54, the radioactive solid waste disposal facility at the Los Alamos National Laboratory. TA-54 is 10cated on Mesita del Buey and is entirely on Laboratory property as shown in Fig. 7. At TA-54, the soil would be handled according to Los Alamos National Lahoratory disposal procedures. ${ }^{16}$ A general description of TA-54 is given in a 1977 Los Alamos Scientific Laboratory report on waste disposal sites at the Laboratory. ${ }^{17}$ The current status of the site is given in the most recent waste management site plan. 18

4.1.4 Transportation Route. Trucks would transport excavated soil along the route outlined in Fig. 7. The distance from the former TA-45 site to TA54 is about $12 \mathrm{~km}$. The transportation route proceeds along Canyon Road to Diamond Drive, Diamond Drive to Pajarito Road, and Pajarito Road to the entry road for TA-54. Although this route proceeds for a few kilometers through the Los Alamos townsite, any alternate route would traverse a greater distance through the townsite. The alternate White Rock route is several times the distance of the route outlined in Fig. 7 .

Diamond Drive and Pajarito Road are heavily used during the hours of 7:00 to 9:00 a.m. and 3:30 to 6:00 p.m. by Laboratory employees commut ing from the LoS Alamos townsite, outlying areas of Los Alamos County, and Española, Santa Fe, and other regional communities. Unpublished data from the 


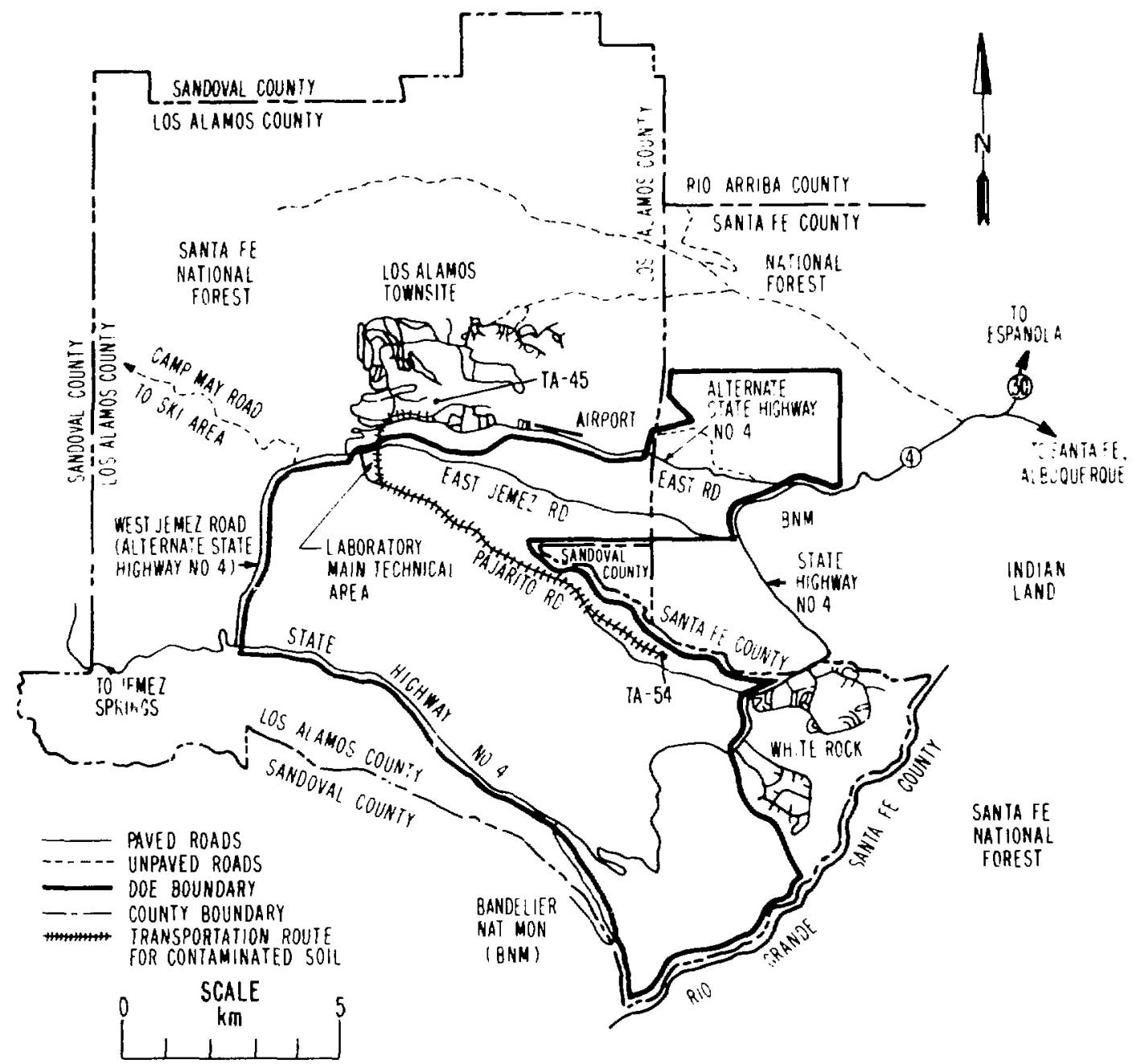

Fig. 7. Location of TA-54 and transportation route from former TA45 site. 
New Mexico State Highway Department and Los Alamos County, taken in the years 1980 and 1982, indicate that the daily traffic along $0 i$ amond Drive between Canyon Road and Trinity Drive averages around 8500 to 9500 one-way trips. The section of Diamond Drive from the Los Alamos Canyon bridge to Pajarito Road and all of Pajarito Road theoretically could be closed to the public, because they are entirely on DOE property.

\subsection{Socioeconomics}

4.2.1 Demography. ${ }^{19}$ Los Alamos County has a population estimated by the preliminary 1980 census at 17 599. Two residential and related commercial areas exist in the County. The LOS Alamns townsite, the original area of development (and now including residential areas known as the Eastern Area, the Western Area, North Community, Barranca Mesa, and North Mesa), has an estimated population of 11039 . The White Rock area (including residential areas known as White Rock, La Senda, and Pajarito Acres) has about 6560 residents. Population estimates for 1980 place 112000 people within an 80-km radius of Los Alamos.

Los Alamos County is a relatively small county, $280 \mathrm{~km}^{2}$ in area, which was formed from portions of Santa $\mathrm{Fe}$ and Sandoval Counties in 1949. At the present time, slightly under 50\% of County land is federally owned by the Los Alamos National Laboratory, the National Park Service, and the US Forest Service. ${ }^{19}$ Almost all of the privately owned 1 and already is developed. Potential residents of the County are frequently forced.to reside in surrounding communities, such as Espanola and Santa Fe, both because of the shortage of residentially developable land and because of the high housing costs resulting from this shortage.

No documented information is available on the public attitude +nward residual radioactivity associated with the Acid/Pueblo Canyon system and the former TA-45 site. The County is aware of the existing problem and is awaiting DOE action.

4.2.2 Economy. ${ }^{20}$ The economy of Los Alamos is based primarily on governmental operations, with that sector directly account ing for about three-fourths of the employment within the County. This employment is associated with the federally funded operations of the Los Alamos National Laboratory and the associated activities of the Zia Company, Los Alamos Constructors, Inc. (IACI), EG\&G, and the Los Alamos Area Office of DOE (LAAO). The direct federally funded employment of the Laboratory, Zia, LACI, EG\&G, and LAAO has averaged around $70 \%$ of total employment since 1967. This has a large impact on the area surrounding Los Alamos County, because about 35\% of the federally supported workers live outside of the County. Within Los Alamos, unemployment is extremely low, averaging around 5\%. The underemployed groups consist primarily of women and adolescents. 
4.2.3 Institutional. ${ }^{20}$ As the only $\mathrm{H}$-class county in the state, the powers of the LOS Alamos County government are granted by the St ate Legislature. The County coordinates planning activities with the North Central New Mexico Economic Development District and the State Planning Office. In 1973, the New Mexico State Legislature passed a law giving the counties responsibility for managing subdivision of 1 and, and LoS Alamos County has since enacted subdivision regulations. The County Comprehensive Plan was adopted in 1964 and revised in 1976. In 1977, the County Zoning Ordinance was revised and adopted.

The Los Aldmos County Charter was adopted in 1967. The County is governed by a seven-member County Council, elected at large. Other elected officials include the County Judge, the County Clerk, the County Assessor, and the County Sheriff. The County Council appoints the chief administrative officers, such as the County Manager, Attorney, and Utilities Manager. The County Council also appoints a five-member Utilities Board, a three-member Board of Equalization, and a nine-member Planning and Zoning Cominission.

DOE has administrative control of all of the Laboratory reservation. The responsibilities of the security force, operated under contract to the Laboratory by the Mason and Hanger-Silas Mason Co., Inc., include policing activities, generally to prevent the entry of unathorized persons into restricted areas. An agreement with the LoS Alamos County Police Department authorizes them to ticket traffic violators on the public access roads across DOE lands. The State Police have authority over state highways, such as State Road 4. The Indian Tribal Police have authority over roads that cross tribal lands. In certain situations, this results in overlapping authorities.

Other federal agencies having resource management responsibilities in the region include the Forest Service and Farmer's itome Administration of the US Department of Agriculture, the US Geological Survey and National Park Service of the US Department of the Interior, the US Army Corps of Engineers, the Bureau of Reclamation, the Bureau of Indian Affairs, the Fish and Wildlife Service, the Soil Conservation Service, and the Agricultural Stabilization and Conservation Service.

Many state agencies have jurisdiction over particular aspects of the County. The State Environmental Improvement Division (EID) has jurisdiction over environmental matters. The State Engineer Office and the New Mexico Water Quality Conirol Commission are responsible for water rights and water quality management. The two interstate compacts affecting water use in the region are the Rio Grande Compact of 1938, amended in 1948, and the Costella Creek Compact. There also is one international treaty, the Rio Grande Convention of 1906. Los Alamos County is a part of the declared Rio Grande Underground Basin. Other important state agencies include the National Resource Conservation Commission, the Department of Game and Fish, and the Parks and Recreation Commission. 
The large percentage of federally owned lands in the region affects the institutional structure of the County. Only Congress is authorized to pass laws affecting the administration of federal property. The Multiple Use and Sustained Yield Act of 1960 and the Classification and Multiple Use Act of 1964 have changed the administration of lands in the region and affected the regional economy.

4.2.4 Community Services. Sewage treatment for the community of Los Alamos is provided by two sewage treatment plants. One is located near the junction of Acid and Pueblo Canyons. The effluent from this piant is discharged into Pueblo Canyon during most of the year but is used to water the municipal golf course during the summer. A larger treatment plant is located just off the eastern end of Kwage Mesa in lower Pueblo Canyon. It discharges continuously into lower Pueblo Canyon. The community of White Rock is served by a County sewage treatment plant that discharges into a tributary of the Rio Grande. There are 10 small treatment plants on Laboratory property, which discharge into canyons on Laboratory property.

Water for Los Alamos County is supplied by a series of wells that penetrate a deep aquifer underlying the Pajarito Plateau at depths ranging from $60 \mathrm{~m}$ at the western edge of the plateau to $180 \mathrm{~m}$ at the eastern edge of the plateau. 20 The water supply system is operated and maintained for DOE by th: Zia Company. The County purchases water from DOE and distributes it to users throughout the County. The water supply system and characteristics are described in a recent report. 21

Electricity for Los Alamos townsite is purchased from DOE by the County and distributed to users throughout the communicy of Los Al amos. Electricity is supplied to the community of White Rock by the Public Service Company of New Mexico.

Natural gas for Los Alamos townsite is purchased from DOE by the County and disinibuted to users throughout the community of Los Alamos. Natural gas service is supplied to the community of White Rock by the Gas Company of New Mexico.

Telephone service to the entire county is provided by the Mountain Bell Telephone Company.

4.2.5 Archaeology. The only portion of the Acid/middle Pueblo Canyon system where archaeology is a ccncern is middle Pueblo Canyon itself. A survey of this canyon has revealed only one group of caveate ruins as an archaeological resource. 22 No archaeological ruins are associated with the former TA-45 site.

In general, evidence exists of sporadic Indian use of the Pajarito Plateau for some 10,000 years. One Folsom point has been found, as well as 
inany other archaic varieties of projectile points. Indian occupation of the area occurred principally from late Pueblo III (late 13th century) until early Pueblo IV (middle l6th century). Continued use of the region well into the historic period is indicated by pictographic art that portrays horses.

Consequently, the plateau and caryons are dotted with hundreds of preColumbian Indiar, ruins. Many of the ruins on the southern part of the plateau are encompassed by $\mathrm{B}$ andelier National Monument. Ruins on Laboratory property have been surveyed by Frederick $C$. V. Worman and, more extensively, by Charlie R. Steen, 23 former Chief Archaeologist of the Southwest Region of the National Park Service and subsequently a consultant to the Los Alamos National Laboratory on archeological matters. Portions of the Pajarito Plateau not included in Bandelier ivational Monument or the Los Alamos National Laboratory have been surveyed more recently by J. N. Hill of the University of California. His findings are not yet published.

There are thrce major ruins on Laboratory property: Tsirege, Cave Kiva, and otowi Ruins. These sites are being considered for romination to the National Register of Historic Places in 1973. This nomination is still pending. The otowi Ruins, comprising two large, unexcavated pueblos, are located in lower Pueblo Canyon, at a point where the canyon wall between Pueblo Canyon and Bayo Canyon is partially broken dowri.

There are hundreds of small ruins on Laboratory property; these also have been submitted for consideration for monination to the National Register of Historic Places." "

\subsection{Soil and Geology}

4.3.1 Soils. The soils in the vicinity of Acid/Pueblo Canyon are clay on the inesa tops, with more sandy soils occurring in the canyon bottoms along the strean beds. The soils are derived from volcanic tuff and, thus, tend to be alkaline in nature, which is unusual for coniferous forest soils. The stream channel consists of granules and sand-sized particles derived from weathering and erosion of the volcanic material. The alluvium is thin in the upper reaches of the canyon and thickens toward the east, becoming 3 to $5 \mathrm{~m}$ thick in the lower part of the canyon.

A recent soil survey'5 discusses many of the canyons and mesas in Los Alamos County. On the basis of information given in that survey, some inferences can be drawn concerning the soils at the former TA-45 site and in Acid/Middle Pueblo Canyon.

The soil at the former TA-45 site probably falls into the Pogna series, which is described as follows. 25 
"The Pogna series consists of shallow, well-drained soils that formed in material weathered from tuff on gently to strongly sloping mesa tops. Included with this soil in mapping are rock outcrop and Carjo, fine Typic Eutroboralf, and Tocil soils; the inclusions make up about $10 \%$ of this mapping unit. Commonly found vegetation includes ponderosa pine, mount ain mahogany, and Kentucky bluegrass.

"Typically, the soil is a light brownish-gray fine sandy loam, or sandy loam, over tuff bedrock at 25 to $50 \mathrm{cr}$. The available water capacity of this moderately ranid permeable soil is $10 \mathrm{w}$, and the effective rooting depth is 25 to $50 \mathrm{~cm}$. Runijf is medium, and there is a moderate water erosion hazard.

"The representative profile of the Pogna fine sandy loam ( 3 to $12 \%$ slope) is descr ided as follows:

Al $0-13 \mathrm{~cm}$, light brownish-gray fine sandy loam, very dark grayishbrown moist; weak fine granular structure; slightly hard and very friable moist; many medium roots; many interstitial pores; neutral: clear smooth boundary.

C 13-30 cm, light brownish-griy fine sandy loam, grayish-brown moist; weak fine granular structure; slightly hard and very friable moist; many medium and coarse roots; many interstitial pores; slightly acid.

R $\quad 30+\mathrm{cm}$, tuff bedrock." 25

Acid Canyon and the upper part of middle Pueblo Canyon could be described as steep rock outcrop. "This land type has slopes greater than $30 \%$ on steep to very steep mesa breaks and canyon walls and consists of about $90 \%$ rock outcrop. The rocks are mainly tuff, except at the lower end of some of the canyons where there is basalt. The inclusions in this mapping unit are very shallow undeveloped soils on tuff, mesic rock outcrop ( 5 to $30 \%$ slope), and frigid rock outcrop (5 to $30 \%$ slope). The south-facing canyon walls are steep and have little or no soil material or vegetation, but the north-facing walls have areas of very shallow dark-colored soils. Veget ation is ponderosa pine, spruce, and fir." 25

With progression down Pueblo Canyon, the steep rock outcrop gives way to a Typic Ustorthents-Rock Outcrop complex, which occupies most of the lower portion of middle Pueblo Canyon.

"The Typic Ustorthents in this complex are deep, well-drained soils that weathered from dacites and latites of the Puye Conglomerate. This complex is found on very steep to extremely steep mountain sideslopes vegetated with a pinon-juniper woodland, interspersed with ponderosa pine. 
"The surface layers of the Typic Ustorthents are generally a pale brown stony or gravelly sandy 10 am about $5 \mathrm{~cm}$ thick. The substratum is about $150 \mathrm{~cm}$ thick and generally consists of a very pale brown or light gray gravelly loamy sand or sand. The effective rooting depth is about $50 \mathrm{~cm}$, and the depth to dacite-latite bedrock is greater than $155 \mathrm{~cm}$. The Typic IJstorthents have noderately rapid to very rapid permeability and a very low available water capacity.

"A typical profile of Typic, 'zurthent, sandy-skeletal, mixed, mesic (64\% slope) is described as follows:

Al 0-6 cm, pale brown gravelly sandy loam, dark brown moist; strong very fine and fine granular structure; nonsticky and friable moist, nonsticky and nomplastic wet; $30 \%$ gravel, $20 \%$ cobble, $10 \%$ stone; abundant very fine and fine roots, plentiful medium roots, few coarse roots; abundant very fine and fine interstitial pores; neutral; clear wavy boundary.

C1 6-18 cm, very pale brown, very gravelly loamy sand, yellowish brown moist; massive structure; slightly hard and friable moist, nonsticky and nonplastic wet; 50\% gravel; few very fine, fine, medium and coarse roots; plentiful very fine and fine interstitial pores; neutral; abrupt wavy boundary dry, clear wavy boundary moist.

C2 18-29 cm, light gray gravelly sand, pale brown moist; massive structure, nonsticky and friable moist, nonsticky and nonplastic wet; weakly cemented; $30 \%$ gravel, $10 \%$ cobble; few very fine, fine, and coarse roots, plentiful medium roots; plentiful fine and medium interstitial pores; neutral; abrupt wavy boundary dry, clear wavy boundary wet.

C3 29-52 cm, very pale brown gravelly sand, yellowish brown moist; massive structure; hard and friable moist, nonsticky and nonplastic wet; weakly cemented; $30 \%$ gravel; few very fine, fine, and medium roots, plentiful coarse roots; plentiful fine and medium interstitial pores; neutral; clear wavy boundary dry, gradual wavy boundary moist.

C4 52-82 cm, very pale brown very gravelly sand, light yellowish brown moist; massive structure; hard and friable moist, nonsticky and nonplastic wet; weakly cenented; $60 \%$ gravel; plentiful fine and medium interstitial pores; mildly alkaline; clear wavy boundry, moist, graduai wavy boundary dry.

C5 82-102 cm, very pale brown very gravelly sand, light yellowish brown moist; massive structure; hard and friable moist, nonsticky and 
nonplastic wet; weakly cemented; $70 \%$ yravel; abundant fine and mediun interstitial pores; mildly alkaline; gradual wavy boundary.

C6 102-122 cm, light gray very gravelly sand, light yellowish brown moist; massive structure; hard and friable moist, nonsticky and 1..nplastic wet; weakly cemented many thick clay films on coarse tragments; $50 \%$ grave 1 abundant fine and medium interstitial pores; moderately alkaline; gradual wavy boundary.

C7 122-153+ cm, white very gravelly loamy sand, light yellowish brown moist; massive structure; nonsticky and friable moist, nonsticky and nonplastic wet; weakly cemented; $40 \%$ gravel; ahundant very fine and fine interstitial pores; moderately alkaline." 25

Toward the lower part of middle Pueblo Canyon, where the canyon bottom begins to widen out, the soils most likely to be found are Puye soils, giving way to Totavi soils in lower Pueblo Canyon. Descriptions of these soils are as follows.

"The Puye series consists of deep, well-drained soils that formed in alluvium in level to gently sloping canyon bottoms near the mountains. Individual areas of Puye soils are 2 to 40 acres in size and occur as long slender bodies. Included with this soil in mapping are areas of this soil with up to $10 \%$ slope on the side of the canyons, and a few intermingled areas of Totavi suils adjacent to the north canyon walls; the inclusions make up about 10\% of this mapping unit. Vegetation commonly found in this soil type includes Kentucky bluegrass, western wheatgrass, mountain muhly, ponderosa pine, oak species, and annual grasses and forbs.

"Typically, the surface soil is a dark grayish brown sandy loam, fine sandy loam, or $10 \mathrm{am}$, to $150 \mathrm{~cm}$ or more. Permeability is moderately rapid, the available water capacity is high, and the effective rooting depth is $150 \mathrm{~cm}$ or more. Runoff is very slow, and the erosion hazard is low. follows:

"A typical profile of Puye sandy loam (0 to 5\% slope) is described as

A1 0-15 cm, dark grayish brown sandy loam, very dark grayish brown moist; weak fine granular structure; soft and very friable moist; many fine and very fine roots; neutral; clear smooth boundary.

C 15-152+ cm, dark grayish brown sandy loam, very dark grayish brown moist; massive; soft and very friable moist; common fine and very fine roots; neutral.

"The Totavi series consists of deep, well-drained soils that formed in alluvium in canyon bottoms in the central and eastern portion of the soil 
survey area. Individual areas are 2 to 60 acres in size and orcur as long slender bodies. Native vegetation is blue grama, pinon pine, one-seed juniper, and annual grasses and forbs.

"The surface soi? is a brown gravelly loamy sand, nr sandy loam, to 150 cm or more, with 15 to $20 \%$ gravel. Permeability is very rapid, runoff is very slow, and the erosion hazard rating is low. The availatsle water capacity is low, but the effective rooting depth is $150 \mathrm{~cm}$ or more.

"A typical perton of Totavi gravelly loamy sand ( 0 to 5\% slope) is described as follows:

AC 0-15? cm, brown gravelly loamy sand, brown moist; single grain; loose dry and moist; few fine roots; $15 \%$ fine qravel; neutral." 25

4.3.2 Geology. I In general, canyons cut into the flanks of the mountains are in rocks of the Tschicora Formation, whereas the canyons of the plateau are cut into and underlain by the Bandelier Tuff (Fig. 8). Along the eastern edge of the plateau, the channels are underlain by the Puye and Tesuque Formations. The basaltic rocks of Chino Mesa, in some areas, are interbedded with sediments of the Puye Formation. The Tesuque Formation forms the valley north of Otowi and is exposed in the lower canyon walls along the Rio Grande in White Rock and lower Los Alamos Canyons.

The rock units, from oldest to youngest, are the Tesuque Formation, Puye Fcrmation, and basaltic rock of Chino Mesa of the Santa Fe Group; the Tschicoma Formation and Bandelier Tuff of the volcanic rocks of the Jemez Mountains; and the alluvium and soil of recent age.

The Tesuque Formation is a sequence of light colored sediments laid down as a coalescing alluvial fan and flood-plain deposits in the Rio Grande depression. The separate beds are composed of friable to moderately welicemented, light-pink-grey to light-brown siltstone and sandstone that contain lensiss of conqlomerate and clay.

The Puve formation consists of two nembers. The lower member is a poorly consolidated, channel-fill deposit, which overlies the Tesuque Formation along the Rio Grande and in Los Alamos and Guaje Canyons. It is a grey, poorly consolidated conglomerate, consisting of fraginents of quartzite, schist, gneiss, and granite ranging in size from sand to boulders; well-sorted lenses of silt and sand are present sporadically. The upper fanglomerate members are composed of uebbles, cobbles, and boulders of rhyolite, lat ite, quartz latite, and pumice in a grey matrix of silt and sand. These rocks were derived from flows associated with the volcanic rocks of the Jemez Mountains. Sorting is poor, but tongues and lenses of well-sorted pumiceous siltstone and water-lain pumice are present with the fanglomerate. 


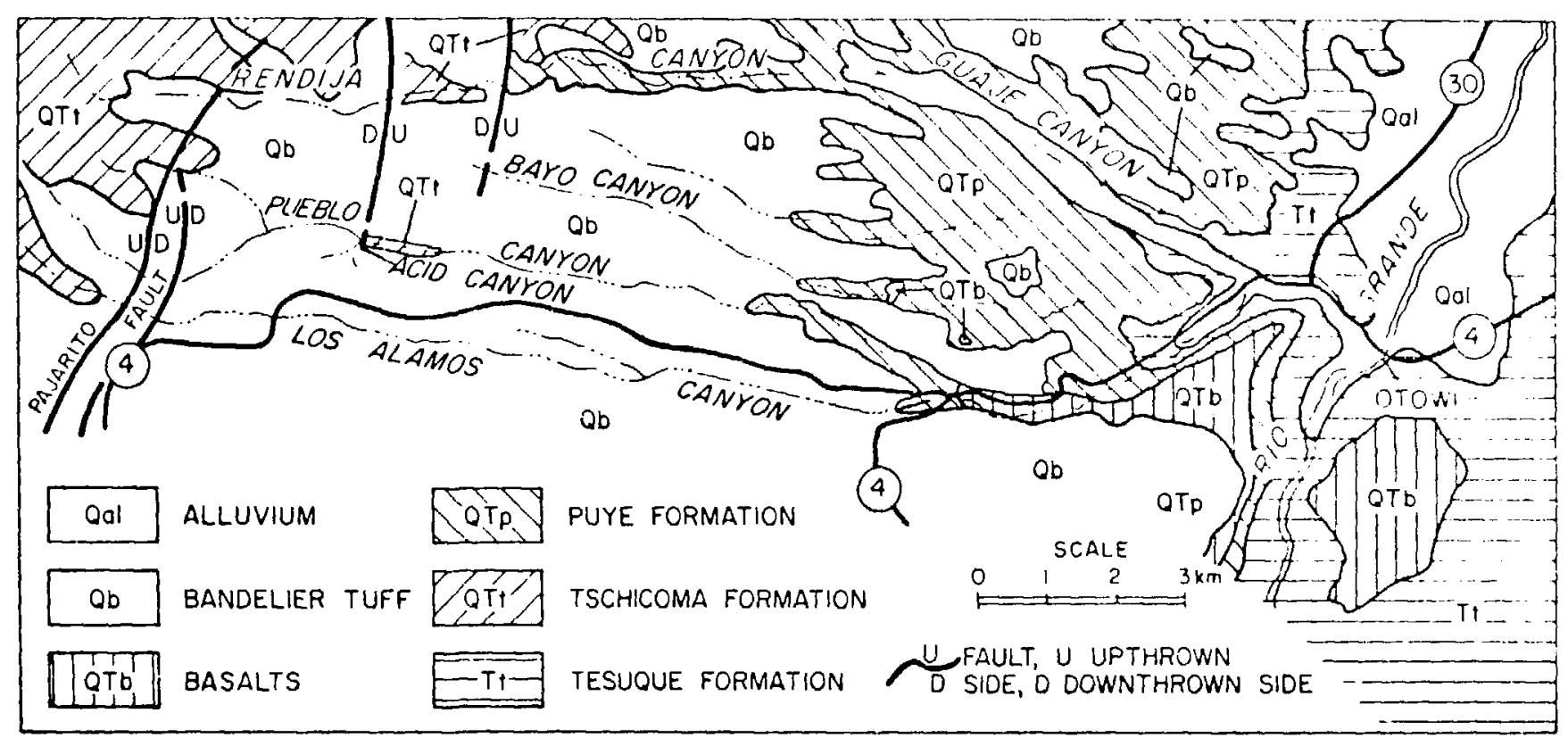

Fig. 8. Geologic map of a part of the Pajarito Plateau in the Los Al amos area. 
The basaltic rocks of Chino Mesa oriqinated from volcanic vents on the Cerros dei Rio to the southeast of the Los Alamos area. The basalt flowed north and northwest into the Los Alamos area, interfingering with the Puye Furmation. The hasalts range in color from grey to black and cont ain varying amounts of olivine, pyroxene, and plagioclase feldspar. Individual flows vary in thickness from a few meters to over $40 \mathrm{~m}$. Sediments inay occur between the individual flows. The basalt caps the mesa of Cerros del Rio and is exposed in the.steep walls of white Rock Canyon.

Volcanic rocks of the Jemez Mountains, along the eastern flanks of the Sierra de los Valles and on the "ajarito Plateau, are of the Tschicoma Formation and the younger fiandelier Tuff. The Tschicoma Formation is composed of undifferentiated latite and quartz latite flows and pyroclastic rocks that are highly fractured and jointed; some intervals contain weathered zones and interflow breccia. These rocks form the core and flanks of the sierra de los valles. The Bandelier Tuff is composed chiefly of ashfall and ashflow tuff with some thil, water-lain sediments. The formation has been divided into three members: Guaje, Otowi, and Tshirege, from the oldest to the youngest. The Bandelier Tuff forms the upper part of the Pajarito Plateau.

The Guaje Melmber of the Randelier Tuff is an ashfall puinice and waterlaid pumicenus tuff that rests unconformably on older rocks. The base of the unit cont ains grey, lamp-pumic? fragments as much as $5 \mathrm{~m}$ in length. Rounded pehble-size fragments of light red rhyolite are present near the top. The ) towi Member of the Bandelier Iuff is a light grey, nonwelded, puniceous rhyolite tuff that weathers to a gentle slope. Quartz and sanidine crystals, l) lass shards, minor amounts of mafic minerals, and varying amounts of rhyolite, latite, and pumice fragments are included in a fine-grained ash. The? Otowi consists of a massive ashflow, with several beds of silt and waterlaid pumice near the top. The Tshirege member of the Bandelier Tuff is composed of a series of ashflows of rhyolite tuff. The Tshirege unconformably overlies the otowi and forms the caprock of the narrow mes as of the Pajarito piateau. The rhyolite tuff is composed of quartz sanidine crystals and crystal fraglicints, rock fragments of rhyolite, dacite, and pumice in an ash matrix that ranges from nonwelded to welded.

Alluvium, eroded from the Sierra de los Valles and the Pajarito Plateau, has been deposited in the canyons of the plateau. Near the heads of the canyons, bedrock is cominomly exposed, but farther down the canyons, alluvium inay be 10 to $30 \mathrm{~m}$ wide and as much as $30 \mathrm{~m}$ thick. Alluvial deposits in the canyons heading on the flanks of the Sierra de los Valles contain cobbles and boulders, with accompanying clay, silt, sand, and gravel derived from the Tschicoma Formation and Bandelier Tuff. Deposits in the canyons heading on the Pajarito Plateald contain r.lay, silt, sand, and gravel derived from the Bandelier Tuff. Clayey soil, derived from weathering of the Bandelier Tuff, covers most of the fingerlike mesas of the Pajarito Plateau. 
The most prominent structural feature of the Pajarito Plateau is the Pajarito Fault Zone, which trends northward along the western edge of the plateau. It is a part of the complex fault system that formed the Rio Grande depression. The depression extends from southern Colorado, through central New Mexico, into northern Mexico. The Pajarito Fault Zone consists of normal faults that are downthrown to the east and displace rocks of the Bandelier Tuff, Puye Formation, and Tschicoma Formation. The displacement, estimated from the fault scarp, is 120 to $150 \mathrm{~m}$ north of Los Alamos and east of the Pajarito Fault. Two normal faults cut the Bandelier Tuff, the Puye Formation, and the Tschicoma Formation. These faults, downthrown to the west, form a depositional basin between them and the Pajarito Fault Zone. These faults extend into the mesa north of Pueblo Canyon. A north-trending depositional basin is formed in tho Tesuque Formation beneath the central part of the Pajarito Plateau. The basin is filled with volcanic debris of the Puye Formation, overlain by the Bandelier Tuff. The bottom of the sedinent-filled trough lies at a depth of about $1500 \mathrm{~m}$ below sea level. The pastern edge of the basin is formed by thick flows of basalt from Chino Mesa, 3 to $6 \mathrm{~km}$ west of the Rio Grande.

Further information on the geology of the Jenez Mountains $c$ an be found in a recent Los $A$ lanos National Laboratory report. 26

\subsection{C ? imatology}

4.4.1 General Climate. ${ }^{19}$ Los Alamos has a semiarid, cont inental mountain climate. The average annual precipitation of $45 \mathrm{~cm}$ is accounted for by warm-season convective rain showers and cold-season migratory storms. Forty per cent of the annual moisture total falls during July and August, primarily from afternoon thundershowers. Winter precipitation falls primarily as snow, with heavy annual accumulations of about $130 \mathrm{~cm}$. Heavy localized thundershowers can at times cause severe runoff events through canyons, with attendant scouring of canyon bottoms.

Summers are generally cool and pleasant. Maximum temperatures are usually below $32^{\circ} \mathrm{C}$. The high altitude, light winds, clear skies, and dry atmosphere allow night temperatures to drop into the $12^{\circ}$ to $15^{\circ} \mathrm{C}$ range. Winter temperatures are typically in the range from $-10^{\circ}$ to $5^{\circ} \mathrm{C}$. Many winter days are clear, with light winds, so that strong solar radiation makes conditions quite comfortable even when air temperatures are cold.

Major spatial and diurnal variations of surface winds in Los Alamos are caused by the complex terrain. Under moderate and strong atmospheric pressure differences, flow is channeled by the major terrain features. Under weak pressure differences, a distinct daily wind cycle exists: a light westerly drainage wind during nighttime hours and a light easterly upslope wind during daytime hours. Interaction of the strong and weak pressure patterns gives 
rise to westerly flow predominance over the Laboratory and a more southerly predominance at the east.end of the mesas.

4.4.? Air Quality. No major emission sources exist in the Los Alamos area, although there are routine sinalt releases of radionuclides and other chemicals by the Laboratory. Data frum routire monitoring systems indicate that, although radiation and radioactivity levels above-background can be dstected, no concentration quidelines (CGS) or other applicable standards are 'seing violatert. 19

Air quality regulation compliance at the Laboratory, a small (50 MW) gas-fired power plant, the zia company asphalt plant, other unit operations, and the general status of air quality recently were reviewed. 27 The review indicated that enission standards and anbient air quality standards are not being violated in the LoS Alanos area. Air quality in the LoS Alamos area should continue to be very good because of the proximity of Bandelier National Monument, the wilderness Area of which is mandated as a Class I area under the Prevention of Significant. Deterioration (PSD) provisions of the Clean Air Act. 28

\subsection{Hydrolugy and Water Qualit ${ }^{1}$}

The Rio Grande, the master stream in northcentral New Mexico, flows Southwostward along the eastern edqe of the Pajarito Plateau (Fig. 7). The Rio Grande recaivos all runoff from the flanks of the Sierra de los valles and the Pajarito Plateau. The main drainage area is about $37 \times 10^{3} \mathrm{~km}^{2} \mathrm{in}$ southern Colorado and northern New Mexico. The surface water discharge of the Rio Grande is measured at the US Geological Survey gauging station at ot owi, located east of LoS Alamos County on State Road 4. The average discharge for $71 \mathrm{yr}$ of record at the station is ahout $40 \mathrm{~m}^{3} / \mathrm{s}$. The stream carries considerable amounts of suspended sediments. The annual suspended sediment load, 1948 through 1975 , has ranged from $6.48 \times 10^{8}$ to $6.86 \times 10^{9} \mathrm{~kg}$ with an annual average of $2.2 \times 10^{9} \mathrm{~kg}$ for the $23-y r$ period of record. The annual volume of flow for this period has ranged from $4.65 \times 10^{8}$ to $1.88 \times 10^{3} \mathrm{~m}^{3}$ with an annua? average of $1.03 \times 10^{9} \mathrm{~m}^{3}$.

Pueblo Canyun heads on the flanks of the Sierra de los Valles. Acid Canyon is tributary to Puebto Canyon near the western edge of the plateau. Surface flow in sections of Pueblo Canyon occurs because of the release of sanitary effluents. As the effluents move downgradient, the surface flow is depleted by infiltration into the alluvium of the strean channel and by evapotranspiration. Thus, the surface flow in the lower reaches of the canyon is intermittent, and only during periods of heavy precipitation does surface flow reach the Rio Grande.

The storm runoff and sanitary effluents infiltrate from the stream channel to recharge simall perennial bodies of ground water perched on underlying 
tuff or volcanic sedinents in the alluvium. The volume of water in these stream-connected alluvial aquifers is largest during the spring from snowmelt and in the early summer from storm runoff. In late summer, fall, winter, and early summer, the volume of water declines. As the water in the alluvium moves downgradient in the canyon, part of it infiltrates into the underlying tuff and volcanic sediments.

Water infiltrating from the alluvium recharges a sinall body of ground water perched in the Puye Formation in the midreach of Pueblo Canyon. The perche aquifer is of limited extent. The Bandelier Tuff does not contain any perched ground water in the Acid-Pueblo Canyon area.

The main aquifer is at a depth of about $380 \mathrm{~m}$ beneath the western edge of the plateau, decreasing to a depth of about $130 \mathrm{~m}$ below the land surface at the confluence of Pueblo and Los Alamos Canyons. The main aquifer is separated from water in the alluvium by over 130 to 300 in of unsaturated tuff and volcanic sediments. It is separated from the perched aquifers in Pueblo Canyon by over 112 to $192 \mathrm{~m}$ of unsaturated volcanic sediments. Thus, there is no hydrologic connection between the shallow alluvial and perched aquifers and the main aquifer.

The upper surface of the main aquifer, the only ground water body capable of water supply, rises westward from the Rio Grande in the Tesuque Formation into the lower part of the Puye Formation beneath the central part of ihe plateau. The aquifer extends into the rocks of the Tschicoma Formation beneath the western edge of the plateau. Movement of water in the aquifer is from the recharge area, deep canyons on the flanks of the mountains and Valles Caldera, eastward to the Rio Grande, where part is discharged to the river from seeps and springs. Transit time of water in the aquifer from recharge area to discharge area is unknown. Tritiun age dating of water from the main aquifer beneath the plateau indicates the water has been in transit for greater than $50 \mathrm{yr}$. Aquifer tests on supply wells and test holes indicate movements ranging from 55 to $220 \mathrm{~m} / \mathrm{yr}$.

\subsection{Biotic Environmental Factors}

4.6.1 General Ecclogy. Community types on the Pajarito plateau range from pinon-juniper woodland with 25 to $30 \mathrm{~cm}$ of rain annually at the eastern, lower part of the plateau to ponderosa pine forest with 45 to $50 \mathrm{~cm}$ annual precipitation at the western, higher edge. The canyons serve as cold air drainage channels from the mountains to the Rio Grande Valley and, thus, tend to be cooler and more moist than the mesa tops above. This allows veget ation typically characteristic of higher elevations to extend farther eastward along the canyon bottoms. The steep-sided and narrow upper portions of the canyons support a pine-fir community, which gives way to ponderosa pine and subsequently to piñon-juniper with progression down the canyons. 


\subsubsection{Plants.}

4.6.2.1 Characterization. The mesa top at the head of Acid Canyon

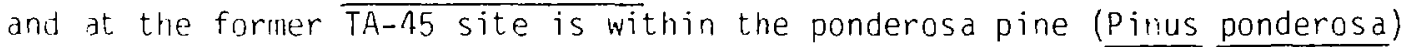
forest. Acid Canyon and the upper portion of middle Pueblo Canyon are steep sided and narrow. This relatively moist and cool environment supports a pine-fir (Pinus ponderosa, Pinus flexilis, Pseudotsuga menziesii, Abies concolor) forest. Lower in middle Pueblo canyon, the pine-fir forest gives way to a ponderosa pine (Pinus ponderosa) forest and finally begins to change to a pinon-juniper (Pinus edulis, Juniperus monosperma) woodland i.oward the lower portion of Pueblo Canyon, where the canyon begins to widen out.

Vequtation near the lower portion of middle Pueblo Canyon was recently surveyed. ${ }^{29}$ A tabulation of the plants found in this survey is given in Appendix B. The most common shrubs and herbs are listed in Table VI. There is no comprehensive survey of either the Acid/upper-iniddle Pueblo Canyon area or the mesa top around the head of Acid Canyon and the former TA-45 site. A prelininary survey ${ }^{30}$ of these areas resulted in the list of species given in Table VI .

4.6.2.? Rare and Endangered Species. A recent study by Foxx and Tierney ${ }^{3}$ has dealt with the status of the flura found on Laboratory property. Inferences concerning ine flora in the areas of interest on the mesa top and in Acid and middle Pueblo canyons were drawn from their report.

There are no species from the Federal [ndanqered and Threatened Species List present on laboratory property. The grama grass cactus (Pediocactus papyracanthus), which is found on Laboratcry property, has been proposed for inclusion in this list. The grara grass cactus prefers drier mesa tops at lower elevations, however, and so it is not likely to be found in the areas of interest in this report.

Appendix C lists plants found in Los Alamos County and protected under New Mexico Statute 45-11. This statute has no penalties associated with it, per se, but destruction of plants covered by it can result in court action if anyone wishes to bring suit.

A list of 350 plant species was submitted by the New Mexico Heritage Progran for consideration for protection under the Federal Endangered and Threatened Species List. Twenty-seven species from this list have been found in or around Los Alamos County, but only pasque flower (Pulsatilla ludoviciana) has definitely been found in moist canyon areas in the vicinity of the Laboratory. Other species, such as woodlily (Lilium umbellatum), perhaps could be found. 
TABLE VI

COMMON HERBS AND SHRUBS OF THE

LOWER MIDOLE PUEBLO CANYON AREA

Grasses and Forbs

Andropogon scoparius

Bouteloua gracilis

Bramus tectorum

KoeTaria cristata

Taraxicum officinale

Verbascum thapsis little bluestem

blue grama

che at grass

Junegrass

dandelion

woolly mullein

Shrubs and Subshrubs

Arteinisia tridentata

$A \vec{r} \vec{F} \Gamma \times$ canescens

$\pi$ vevehamnus nauseosus

$\because$ a rugia paradoxa

- iestiera neomexicana

Gut ierrezia microcephala

Prunus virginiana. var. mel anocarpa

Quercus gambe 5.

Quercus unduTata.

Rhus triTobat a

Robinia neomexicana big sagebrush

saltbush

chamisa or rabbitbrush

Apache plume

New Mexico olive

snakeweed

chokecherry

Gambel oak

scrub oak

squawbush

New Mexico locust

\section{Disturbed Habitat Plants}

Artemisia frigida

Chenopodium fremont i

Chrysopsis villosa

Croton texensis

Cryptantha james i

Erodium circut arium

Helianthus petiolaris

Lupinus caudatus.

Mirabilis mult iflora

Salsota kali

Viguiera multiflora wormwood

1 ambsquarters

goldenweed

doveweed

James cryptantha

filaree

prairie sunflower

lupine

wild four o'clock

Russian thistle or

tumb leweed

crownbeard 


\section{PLANTS OF TA-45/ACID/MIDDLE PUEBLO CANYON}

Sites: 1. TA-45 Treatinent Plant Site

2. Mesa Top Adjacent to Head of Acid Canyon

3. East Facing Slope of Upper Acid Canyon

4. Acid Canyon Bottom and Stream Channel

5. Upper Purtion of Middle Acid Canyon, Broad Section

6. Middle Pueblo Canyon Stream Channel

7. Ipper Portion of Middle Pueblo Canyon, Narrow Section

Species

Abies concolor - white fir

Acer glabrum - New Mexico maple

Agrostis alba - redtop

Allium Cernuulil - wild onion

Ainaranthus retroflexus - piqweed

Andropogon scoparius - 1itt le bluestem

Antennaria parvifolia - pussytoes

Arctostaphylos uva-ursi - bearberry

Artemisia dracunculus - false terragon

Artemisia ludoviciana - wormwood

Aster novae-angliae - aster

Berberis fendleri - barberry

Betula occidentali8s - birch

Blepharoneuron tricholepis - pine dropseed

Brickellia spp. - brickelbush

Bromus spp. - bromegrass, cheatgrass

Castilleja integra - Indian paintbrush

Cercocarpus mont anus - mount ain inahogany

Chenopodium spp. - I ambsquarters

Chrysopsis villosa - golden aster

Circium spp. - thistle

Clematis pseudoalpina - Rocky Mt. clemat is Conyza canadensis - horseweed

Cornus stolonifera - dogwood

Dactylis glomerata - orchard grass

$a_{\text {Bullet }}(\bullet)$ denotes dominant species.
Locat ion ${ }^{\text {d }}$

\begin{tabular}{lllllll}
\multicolumn{1}{c}{ Location $^{\text {d }}$} \\
1 & $\underline{2}$ & $\underline{3}$ & $\underline{4}$ & $\underline{5}$ & $\underline{6}$ & $\underline{7}$
\end{tabular}

0

o 0

$\circ$

$\circ$

o

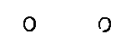

0
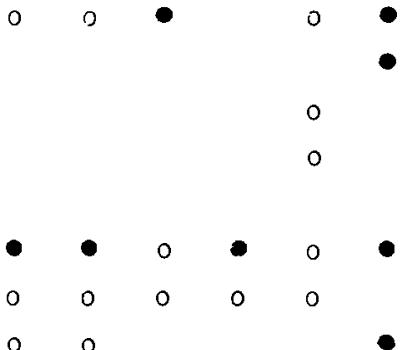

- 0

0

$\begin{array}{lllll}0 & 0 & 0 & 0 & 0\end{array}$

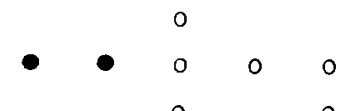

0 o 0

$\circ \bullet 0$

000

$0 \quad 0$

0

- 0

$\begin{array}{lllll}0 & 0 & 0 & 0 & 0\end{array}$

o

00

o

0

0

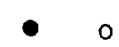


Species

Elaeagnus angustifolia - Russian olive

Elymus canadensis - wild rye

Erigeron spp. - fleabane

Erodium circut arium - neronbill

Eupatorium herbaceum - throughwort

Fallugia paradoxa Apache plume

Fragaria bracteata - wild strawberry

Franseria confertifolia - bursage

Grindelia aphanactis - gumweed

Helianthus annuus - sunflower

Helianthus petiolaris - prairie sunflower

Hymenoxys richardsoni - pinque

Ipomopsis longiflora - blue skyrocket

Iva spp. - marsh-elder

Jamesia americana - cliffbush

Juniperus monosperma - one-seed juniper

Kochia scoparia - summer cypress

Koeleria cristata - Junegrass

Liatris punctata - gayfeather

Monotropa lat isquama - pines ap

Muhlenbergia montana - mount ain muhly

Oenothera spp. - evening primrose

Pachystima myrsinites - myrt le boxleaf

Panicum capillare - witchgrass

Parthenocissus inserta - woodvine

Penstemon barbatus - scarlet bugler

Picea pungens - blue spruce

Pinus flexilis - limber pine

Pinus ponderosa - ponderosa pine

Phleum pratensis - Timothy

Polygonum ramosissimum - knotweed

Populus tremuloides - quaking aspen

Potentilla pulcherrima - cinquefoil

Pseudotsuga menziesii - Douglas fir

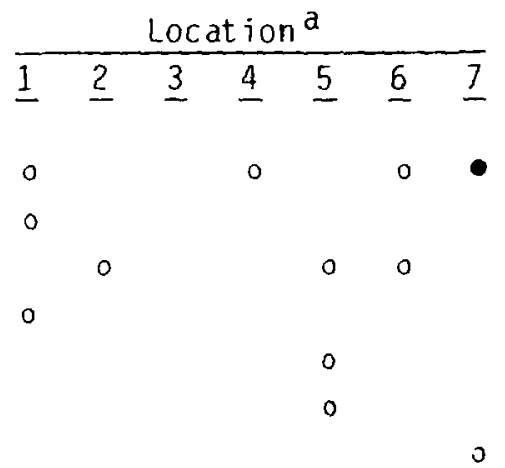

0

0

o

○

0

o

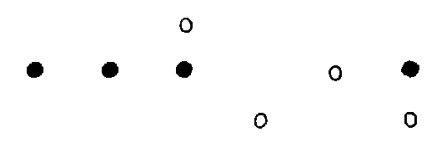

0

o

o

0

o

0

$0 \quad 0$

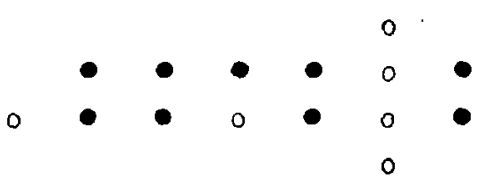

o

0

$0 \quad 0 \quad 0$ 


\section{Species}

Quercus gambelij - Gambel oak

Rhus radicans - poison ivy

Ribes cereum - wax currant

Rosa spp. - wild rose

Rubus strigosus - raspberry

Rumex spp. - dock.

Salix spp. - willow

Salsola kali - Russian thistle, tumbleweed

Senecio spp. - groundse?

Sitanion hystrix - squirreltail

Solidago spp. - goldenrod

Sphaeralcea spp. - globe mallow

Sporobolus Spp. - dropseed

Tragopogon dubius - goatsbeard, salsify

Ulmus spp. - elm

Valeriana acutiloba - valerian

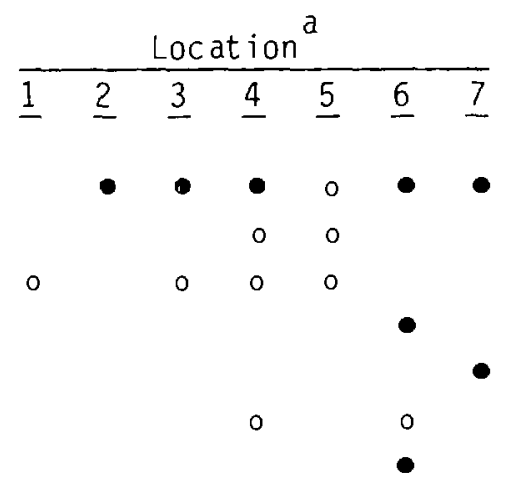

4.6.3 Animals.

4.6.3.1 Characterization. Little quantitative information concerning the fauna of the Los Alanos area is available. Species lists are presented in the Environmental Impact Statement 20 for the Los Alamos Scientific Laboratory site. These lists are included as Appendix $D$ of this report. The lists are, however, uncertain. occurrence of some species is unverified, although sightings have been reported, and other species that are not in the list are suspected to be present.

A hiotic survey conducted by Miera et $21 .{ }^{32}$ in Acid-Pueblo Canyon and other liquid-effluent receiving areas noted the presence of 14 small mammal species, verified by trapping or sighting. These species are listed in Table VIII.

4.6.3.2 Rare and Endangered Species. Table IX gives a list of endangerec. and threatened species developed for northcentral New Mexico by the New Mexico State Game Commission. ${ }^{20}$ Although several of these species have been documented in LoS Alamos County, the only one known to be present in proximity to Acid/middle Pueblo Canyon is the peregrine falcon (Falco peregrinus). There is a peregrine falcon aerie in lower Pueblo Canyon, and the falcons use middle Pueblo Canyon as a hunting area. 
TABLE VIII

MAMMALS TRAPPED OR SIGHTED IN ACID/PUEBLO CAṆYGIY

Eut amius minimus

Microtus pennsyivanicus

Mus muscuTus

Neot oma mexic ana

Peromyscus maniculatus

Peromyscus truei

Reithrodont omys megalot is

sciurus aberti

Sigmodon Gispidus

Sorex nanus

Spermophilus lateralis

Spermophitus variegatus

Sylvilagus $5 p$ p.

Thomomys bott ae least chirmunk

meadow vole

house mouse

Mexican woodrat

deer mouse

pinor, mouse

western harvest mouse

tassel-eared squirrel

hispid cotton rat

dwarf shrew

golden-mantled squirrel

rock squirrel

cottontail rabbit

valley pocket gopher

Another species that may very likely be present in Pueblo Canyon, at least in the upper reaches, is the Jemez Mountain salamander (Plethodon neomexicanus). Although this species never has been dccumented in Pueblo Canyon, it is known to be present in Los Alamos Canyon, which is one canyon south of Pueblo Canyon. The moist environment in Pueblo Canyon caused by sewage treatment plant effluent makes the canyon an ideal habitat for the salamander. A faunal survey of Pueblo Canyon to ascertain whether the salamander is there has never been conducted.

No other endangered or threatened species are suspected of being present in the Acid/middle Pueblo Canyon area.

\subsection{Sunmary of Radiological Conditions ${ }^{1}$}

\subsubsection{Radioactivity in Soils and Sediments.}

4.7.1.1 Present Conditions. The data for the Acid/Pueblo Radiological Survey were taken in 1976-1977. Since that lime, the routine soi? and sediment sampling program conducted by the Environmental Surveillance Group at the LoS Alamos National Laboratory has included radiochenical analyses of soil and sediment samples from the Acid/Pueblo Canyon system. These dat a have been reported in the annual surveillance reports. $19,33-36$ A summary of the results of the more recent radiochemical sediment analyses of samples from Acid Canyon is presented in Table $x$. The annual data from the 
TABLE IX

STATE-LISTEO ENDANGEREO ANIMAL SPECIES FOR NORTHCENTRAL NEW MEXICO

\begin{tabular}{|c|c|c|}
\hline & $\begin{array}{c}\text { Group } 1 \\
\text { Endangered }\end{array}$ & $\begin{array}{l}\text { Group } 2 \\
\text { Threatened }\end{array}$ \\
\hline Marnmals & $\begin{array}{l}\text { Black-fuoted ferret } \\
\text { River otter }\end{array}$ & $\begin{array}{l}\text { Pine marten } \\
\text { Minka }\end{array}$ \\
\hline Birds & $\begin{array}{l}\text { Peregrine falcon } \\
\text { Whooping crane } \\
\text { White-tailed ptarmigana } \\
\text { Sage grouse } \\
\text { Mexican ducka } \\
\text { Bald eagle }\end{array}$ & $\begin{array}{l}\text { Osprey } \\
\text { Red-headed woodpecker } \\
\text { Zone-tailed hawk }\end{array}$ \\
\hline Ampnibians & & Jemez Mountain salamander \\
\hline Fish & $\begin{array}{l}\text { Shovelnose sturgeon } \\
\text { (exterminated) } \\
\text { Bluntnose shiner }\end{array}$ & Suckermouth minnow ${ }^{a}$ \\
\hline
\end{tabular}

TAELF $X$

XIIMENT MHALYSES FRUM AEID CANYON

\begin{tabular}{|c|c|c|c|c|c|c|c|c|}
\hline & $\begin{array}{r}13 / C s \\
(p c 1 / g) \\
\end{array}$ & $\begin{array}{r}2+1 / \mathrm{sm} \\
(p c i / y)\end{array}$ & $\begin{array}{c}\text { fir } \\
(p(i / g)\end{array}$ & $\begin{array}{r}3740 \\
(p 63 / g)\end{array}$ & $\begin{array}{c}\therefore{ }^{4} p_{u} \\
\{\rho(i / g)\end{array}$ & $\begin{array}{l}\text { Gross a } \\
\text { (pcivg) }\end{array}$ & $\begin{array}{l}\text { Gross } 3 \\
(p C i / g)\end{array}$ & $\begin{array}{l}\text { Total U } \\
(n y / g)\end{array}$ \\
\hline $\begin{array}{l}1981 \\
1990\end{array}$ & $\begin{array}{l}1.0: 0.2 \\
10.8 \div 0.20\end{array}$ & $0.449: 0.1) 32$ & $1.23+10.28$ & $\begin{array}{l}0.035 \cdot 0.1) 3 ? \\
0.039 \div 0.11089\end{array}$ & $\begin{array}{l}14.9+1.110 \\
6.46\end{array}$ & $\begin{array}{r}11: 4.0 \\
7.7 \div 3.2 \\
17 \div 8.0\end{array}$ & $\begin{array}{l}3.9 \pm 1.0 \\
4.2: 1.2 \\
9.2: 2.1\end{array}$ & $2.1 \div 0.4$ \\
\hline $\begin{array}{l}1979 \\
1979 \\
1971 \\
1976-77^{d} \\
\text { Acid Canyon }\end{array}$ & $\begin{array}{l}1.03+0.13 \\
0.68+0.06\end{array}$ & $0.351 \cdot 0.024$ & $0.68 \div 0.20$ & $\begin{array}{l}0.0168+0.018 \\
0.034+0.0188\end{array}$ & $\begin{array}{l}10.6 \div 0.60 \\
5.62 \div 2.39 \\
1.24+0.653\end{array}$ & $\begin{array}{r}1.4 .0 \\
7.5: 3.2 \\
2.7 \cdot 0.8\end{array}$ & $\begin{array}{l}6.0 \div 1.4 \\
4.5 \div 1.2 \\
2.9: 1.6\end{array}$ & $\begin{array}{l}? .7: 0.6 \\
1.6: 0.1\end{array}$ \\
\hline $\begin{array}{l}\text { Acid Canyon } \\
\text { Channel Average } \\
\text { Range }\end{array}$ & $\begin{array}{l}1.9 \div 4 \\
(0.2-12.1)\end{array}$ & $(0.33-43.4)$ & $\begin{array}{c}1.1) \cdot 1.4 \\
(0.4-4.5)\end{array}$ & $(0-3.13)$ & $\begin{array}{c}31+24 \\
(5.2-629)\end{array}$ & $\left.\left.\left(7^{\prime}\right)-580\right)\right]$ & $(1-9)$ & $\begin{array}{l}1.3 ! 1 \\
(2.8-10)\end{array}$ \\
\hline
\end{tabular}


surveillance reports generally fall into the lower end of the range of values reported in the radiological survey. The data show no particular trend. The apparent drop in some concentrations from the averages reported in the radiological survey (see Table $x$ ) is explained by noting that, during the survey, radiochemical analyses were performed only c. simples for which highgross alpha and/or beta counts were recorded. survey. 1

Sections 4.7 .1 .2 and 4.7 .1 .3 summarize the data from the radiological

4.7.1.2 Concentrations. The distribution pattern of $239 \mathrm{Pu}^{\star}$ on sediments and soils is displayed in Fig. 9. Quantitative data summaries are also presented in Table XI. The most important features of the pattern include the following.

- The highest concentrations are associated with the untreated waste outfall (Treatment Plant Site Surface, Figs. 5 and 9).

- Some subsurface residual radioactivity is present in the immediate area of the former waste treatment plant location and along part of the alignment of the former industrial waste line (Treatment Plant Site Subsurface, Figs. 5 and 9).

- Plutonium is present at above-background levels in all the channels and banks from the discharge points in Acid Canyon, through middle and lower Pueblo Canyon, and in lower Los Alamos Canyon (Fig. 9).

- Concentrations in the channels and banks generally decline with increasing distance from the discherge points (Fig. 9).

- The banks have higher concentrations than channels in given intervals, as would be expected from the intermittent strean character that scours the channels more frequently than the banks (Fic. 9).

A number of other facts are important to understanding the overall pattern of occurrence and distribution of radioactivity in the affected areas. These include the size of the areas, the isotopes other than $239 \mathrm{pu}$ present, and the variability of the data collected.

The affected area having subsurface residual radioactivity in the vicinity of the former waste treatment plant site is generally within a rectangle about $55 \mathrm{~m}$ by $60 \mathrm{~m}$ and within about $2 \mathrm{~m}$ depth from the surface (Fig. 5 and Table XI). Another smaller area along the alignment of the former waste line is about 40 by $3 \mathrm{~m}$ and within about $1.5 \mathrm{~m}$ depth from the surface.

The highest concentrations of surface residual radioactivity (depths to about $30 \mathrm{~cm}$ ) in the vicinity of the Treatment Plant site are adjacent to the

*The designation $239 \mathrm{pu}$ is used in this discussion to siynify the sum of $239 \mathrm{Pu}$ and $240 \mathrm{pu}$. These isotopes are not separately distinguishable by normal alpha spectroscopy because their aipha particles have nearly the same energies. 


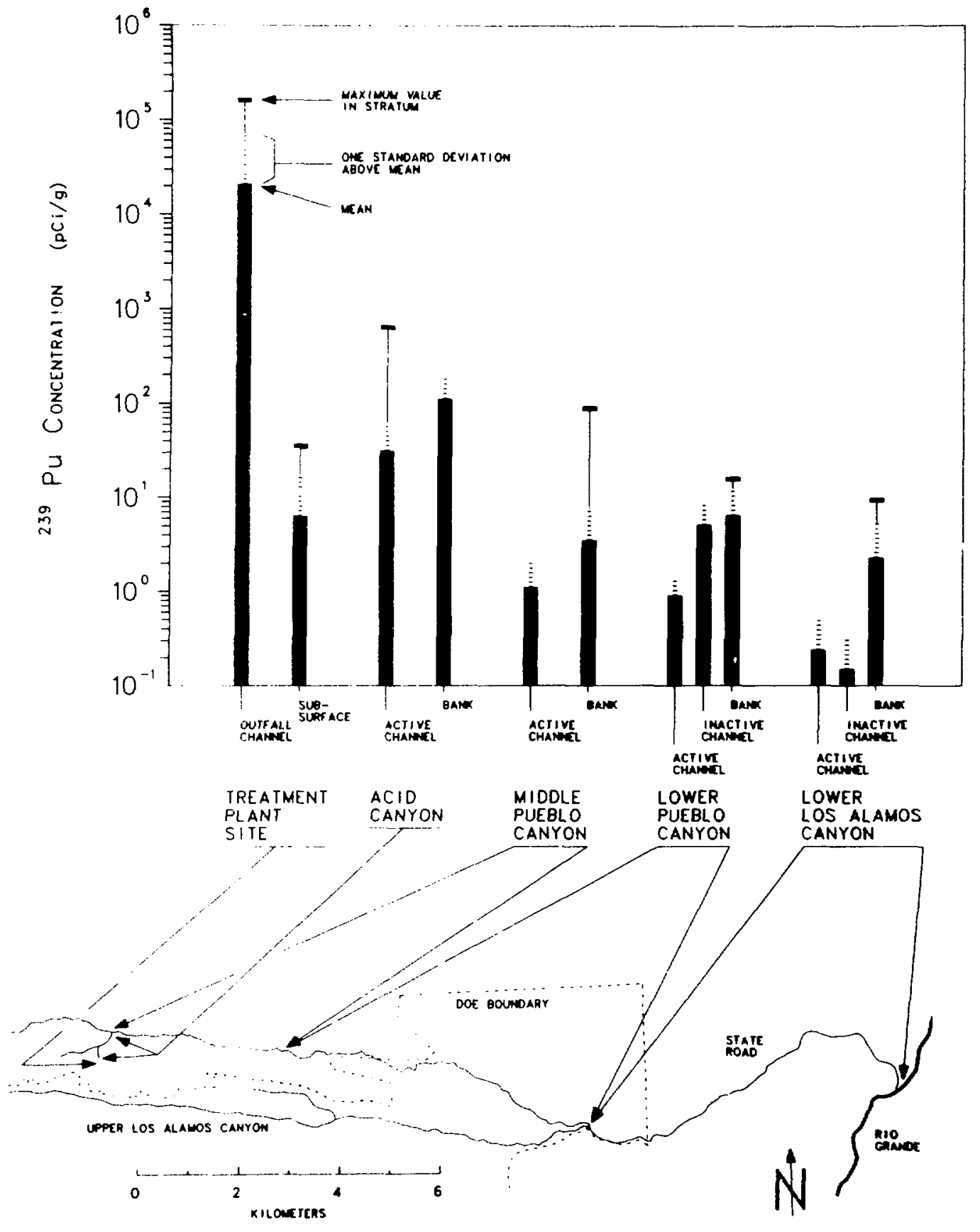

Fig. 9. Concentration of ${ }^{239} \mathrm{pu}$ on soils and sediments by locatiori. 


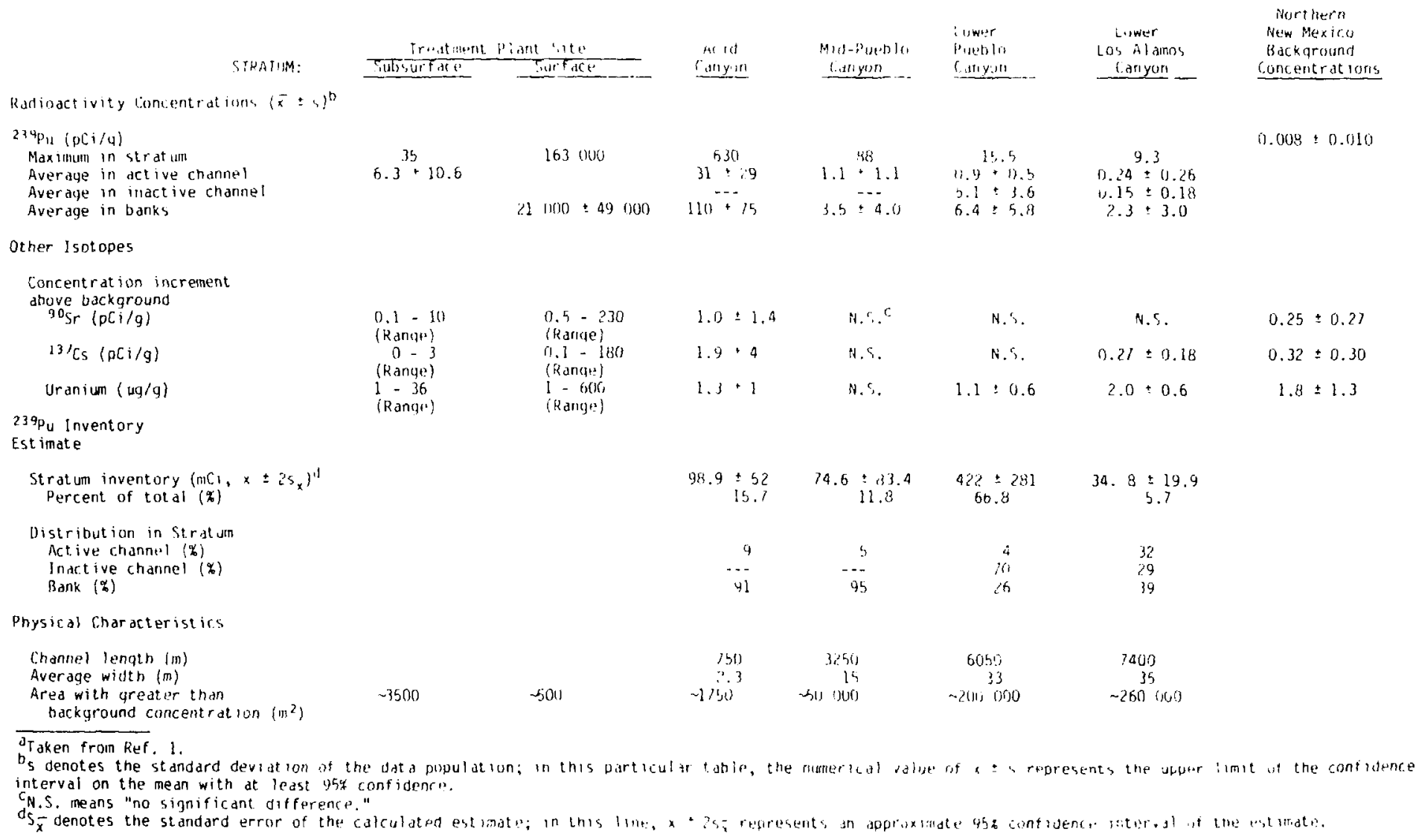


natural drainage channel that received the untreated effluent (Fig. 5). This area is about $30 \mathrm{~m}$ long and no more than $5 \mathrm{~m}$ wide. Within it, maximum concentrations occur within a band of elevated activiij about 30 to $70 \mathrm{~cm}$ wide along the channel and are in spots having dimensions on the order of $15 \mathrm{~cm}$ as determined by portable instruments. Additional, but considerably lower, surface activity was primarily associated with the natural drainage area leading from the former vehicle decontamination facility toward the canyon edge. This area is roughly 10 by $30 \mathrm{~m}$.

Within the canyon seginents the affected areas have widths averaging between about 2.3 and $35 \mathrm{~m}$ and have a total length of about $17.5 \mathrm{~km}$ Table XI). Throughout the canyons the activity is largely confined to depths of about $30 \mathrm{~cm}$.

Transuranic radioactive isotopes present in addition to ${ }^{239} \mathrm{pu}_{\mathrm{u}}$ include

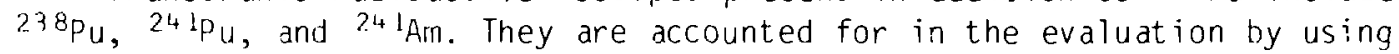
ratios of their activities to the activity of $239 \mathrm{pu}$, as shown in Table XII. A single set of ratios for current conditions was assumed for all study areas to simplify presentation of the results. The values were based on radiochemical analyses performed on a subset of the samples analyzed for $239 \mathrm{Pu}$ and/or judgment of other factors, including variability of analyses and worldwide fallout. Future condition ratios were calculated from the current condition ratios to account for the decay of $238 \mathrm{pu}$ and $241 \mathrm{Pu}$ and the ingrowth of $2{ }^{4} \mathrm{Am}$. This use of a single set of ratios for all areas means the estimates of contrihutions from ${ }^{24} \mathrm{P} \mathrm{Pu}$ and ${ }^{24} \mathrm{Am}$ in Acid Canyon are probably overstated by factors of as much as 5 to 10 compared to the rest of the areas.

Dther radioactive isotopes present at concentrations with statistical significance above background in dt least some areas include ${ }^{90} \mathrm{Sr},{ }^{13}{ }^{\prime} \mathrm{Cs}$, and uranium. Data for these constituents are summarized in Table XI. The values given are the statistically significant increment above regional background values. Where there was no significant increment (significance level $\alpha=$ $0.05)$, the entry in the Table is "N.S."

Even though a large number of samples were collected and analyzed, the physical areas involved and the complex natural processes involved in the dispersion of the radioisotopes from the discharge points made representative sampling extremely difficult. This is reflected clearly in the standard deviations of the concentrations presented in Table XI. In most cases, the standard deviations are about the same value as the mean. The consequence of this is that all subsequent analyses of information based on the concentrations have a large uncertainty and can generally be considered to be accurate only within a factor of about 2. Most of the results are rounded to two significant figures to maintain reasonable consistency in the presentation, but even this probably implies more precision than is warranted. Within the ranges of uncertainties discussed, and considering the fact that runoff 
events do redistribute sediments within the channels, measurements made during this study are compatible with values obtained during previous special and monitoring studies (Ref. 1).

The standard deviations of the concentration data are given in Table $X I$ to indicate the large variability in the values. Because of the large variability, the mathematical standard deviation could be misinterpreted to mean that some of the actual concentrations were negative, an obvious physical impossibility. The standard deviations in such cases should be interpreted to indicate that the majority of the individual concentrations were between zero and the mean plus the standard deviation.

Preliminary evaluations of the data were performed using geomietric means, because physical processes such as hydrologic transport often have been found to be well described by some type of extreme value distribution. These evaluations gave means that were often about one-third the arithmetic means but had much larger standard deviations. The concentration data sets were too small to permit a clear choice between arithmetic and geometric mean representations. Accordingly, the arithmetic means were used for subsequent analyses of potential effects because they are simpler, are less likely to understate effects, and are the preferred statistical estimators for inventory calculations.

For inventory calculations, the standard errors of the means of both concentrations and channel widths were used to estimate confidence intervals of the computer inventories.

\subsubsection{Estimated Inventory. Estimates of the amount of $239 \mathrm{pu}$} present in the affected canyon segments were calculited for two purposes. They provide a basis for making qualitative predictions of future redistribution by hydrologic transport of sediments, and they provide a basis for evaluating the plausibility of this analysis in accounting for the estimated releases into the canyons.

The $239 \mathrm{pu}$ inventories were estimated as the product of the average concentrations in the channels and banks of each segment and the estimated mass of affected sediments and soils derived from average measured physical dimensions and density. These estimates are depicted graphically in Fig. 10. Quantitative estimates are summarized in Table XI. Two major features of the pattern are evident.

- Most of the plutonium is associated with the banks and inactive channels. This is as expected, because the intermittent stream flow inundates the higher ground less frequently than the active channel.

- The ?argest proportion, about 67\%, of the plutonium is found in lower Pueblo Canyon. This also is as expected, because the wider, flatter channel reduces flowrates and leads to deposition of suspended sediments. 


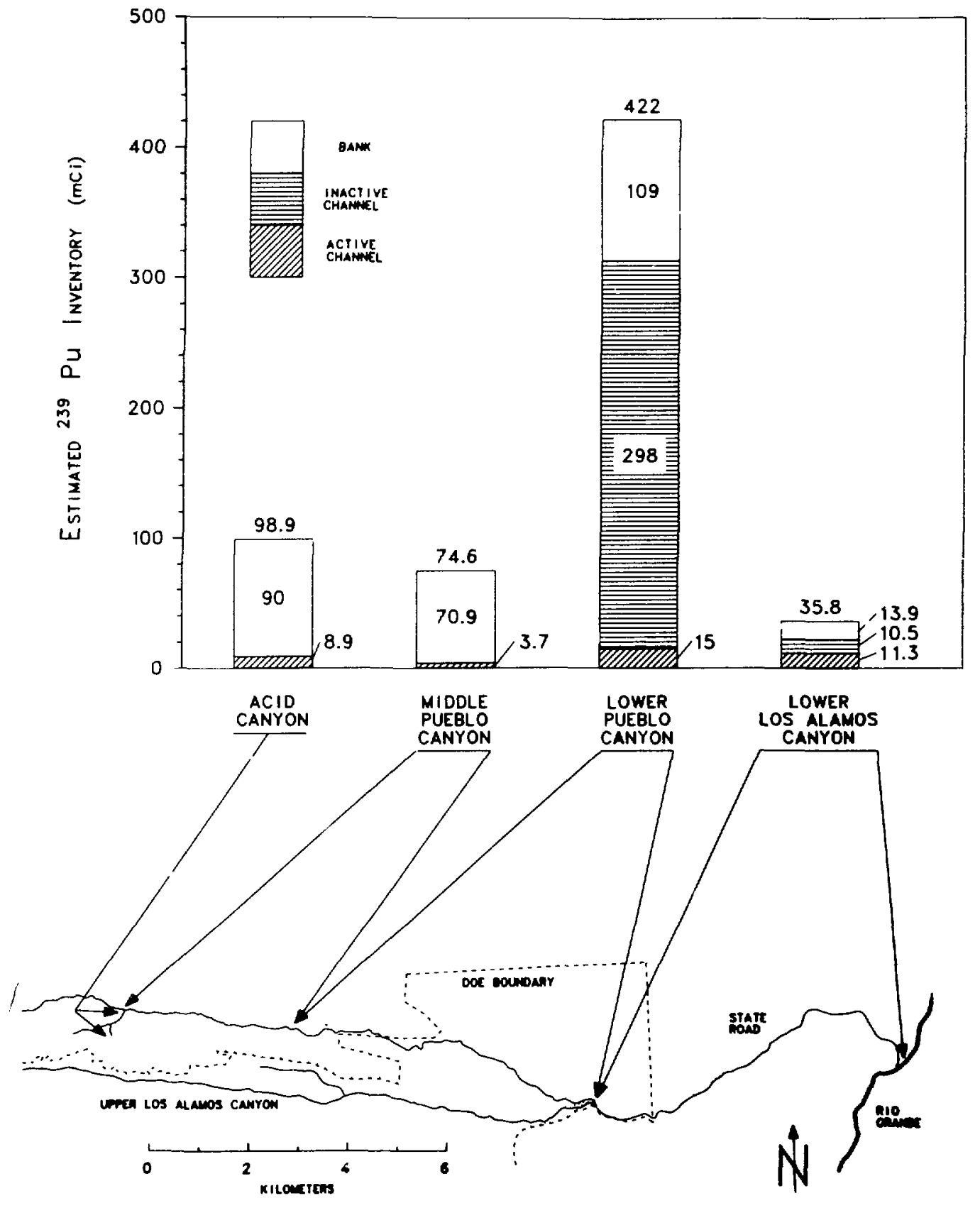

Fig. 10. Estimated inventary of ${ }^{239} \mathrm{pu}$ on soils and sediments by location. 
The total estimated inventory, based on arithmetic means, is about $630 \pm$ $300 \mathrm{mCi}$ (approximate 95\% confidence interval), or $7.9 \pm 3.8 \mathrm{~g}$. This is about 3 times the total of estimated and measured releases into Acid Canyon and the still-onsite DP Canyon, which discharges into LoS Alamos Canyon. This is reasonable agreement given the uncertainties discussed in this section.

No quantitative inventory estimate was made for the Treatment Plant site because of the extremely spotty nature of the residual radioactivity and the small volume of potentially affected material in comparison with the canyon areas.

4.7.2 Airborne Radioactivity. Radioactivity on soils and sediments can be redistributed in the environment by resuspension, whereby sinall particles of soil or dust are noved and become airborne through the action of wind or other inechanical forces. This raises the possibility of exposure to the radioactivity through inhalation. This potential mechanism, or pathway, was examined by analyzing actual measurements of airborne radioactivity in the vicinity of LOS Alamos and by applying a simple theoretical model to the canyon sediment and soil radioactivity data.

4.7.2.1 Present Conditions. Information for the Acid/Pueblo Radiological Survey ${ }^{1}$ was assembled from data collected by the air sampling network maintained as part of the routine environmental surveillance program at the Los Alamos National Laboratory. Data from 1974 through 1978 were used in the radiological survey. The same air sampling network still is in operation, and Table XIII presents data from the network for 1979-1981, 19,35- 36 along with the 1974-1978 data used in the radiological survey.

The stations for which data are presented include four on mesa tops at $v$ arious distances from the TA-45/Acid/Middle Plieblo site. These are Cumbres School, TA-21, Los Alamos Airport, and Bandelier stations, in order of increasing distance from the TA-45/Acid Canyon site. The Bayo Sewage Plant station is near the midpoint of lower Pueblo Canyon, and the Santa Fe station is located about $40 \mathrm{~km}$ to the southeast.

Although there appear to be large fluctuations in the data presented in Table XIII, these fluctuations generally are within the uncertainties of the analyses and represent year-to-year fluctuations rather than variation among stations. There is no indication that any of the stations are being influenced by resuspension from TA-45/Acid/middle Pueblo Canyon.

Sections 4.7.2.2 and 4.7.3.3 summarize the data from the radiological survey. 1

4.7.2.2 Measurements. The basic conclusions presented in the radiological survey on the basis of analysis of the 1974-1978 data include the following. 
RELATIONSHIP OF 239 PU ANG

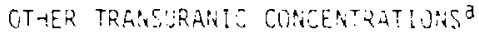

\begin{tabular}{|c|c|c|}
\hline \multirow{3}{*}{$\begin{array}{c}\text { Activity } \\
\text { Ratio }\end{array}$} & \multicolumn{2}{|c|}{ Values lised for analysis } \\
\hline & Current & Future \\
\hline & Condition ( $197:$ & Condition ( 205$)^{\prime}$ \\
\hline $233 p_{u}, 239 p_{u}$ & 0.03 & 0.017 \\
\hline $241 p_{u} / 239 p_{u} D$ & 1.5 & 0.045 \\
\hline $241 \mathrm{An} / 239 \mathrm{pu}$ & 0.1 & 0.15 \\
\hline
\end{tabular}

ataken from Ref. 1.

bplutonium-241 is prillarily a B-particle enitter; the activity ratios in the table are for total activity; a-activity is ahout

$0.002 \%$ of the tota?

IABLE $X[1]$

ANRUAL AVTRAGE $239 \mathrm{Pu}$ ALR CONCFNTRATIONS

\begin{tabular}{|c|c|c|c|c|c|c|c|c|}
\hline Loc at ion & 1974 & 1975 & $19 / 6$ & 1571 & 1978 & 1979 & 1980 & 1981 \\
\hline $\begin{array}{l}\text { Bayo Sewage Plant } \\
\text { (Bottorn uf Lower } \\
\text { Pueblo (anyon) }\end{array}$ & $27 \cdot 3$ & $19: 2$ & $5.1 \div 1.15$ & $65+240$ & $27: 61$ & $4.8+6.3$ & $3.5=3.4$ & $12 \pm 13$ \\
\hline $\begin{array}{l}\text { Cumbres School } \\
\text { (North Rim, Middle } \\
\text { Pueblo Canyon) }\end{array}$ & $31: 4$ & $15 \pm 2$ & $4.0 \div 0.9$ & $13 \div 39$ & $24: 47$ & $25+91$ & $4.0 \div 2.7$ & $14 \pm 15$ \\
\hline $\begin{array}{l}\text { Los Alamins Airport } \\
\text { (South Rim, Lower } \\
\text { (Pueblo Canyon) }\end{array}$ & $25 \pm 2$ & $24: 4$ & $6.8 \div 1.1$ & $18 \cdot 28$ & $20: 41$ & $4.8: 5$ & $9.8: 16$ & $14 \div 8$ \\
\hline Technical Ared 21 & $23 \div 2$ & $18 \div 2$ & $6.2: 1.1$ & $21 \cdot 32$ & $23: 51$ & $6.1 \cdot 10$ & $1.2: 2.0$ & $4.6 \pm 4.2$ \\
\hline Bandelier & $32 \div 3$ & $23 \pm 2$ & $6.2 \div 1.2$ & $28 \cdot 58$ & $40: 66$ & $6 \cdot 10$ & $0.8+1.8$ & $19 \pm 14$ \\
\hline Santa Fe & $21 \div 2$ & $16 \div 2$ & $3.8: 0.8$ & $16 \div 23$ & $24: 46$ & $3.6 \div 2.2$ & $0.1 \div 0.9$ & $1.2 \div 9.6$ \\
\hline New York City & 39 & 20 & 6.0 & 21 & $\begin{array}{l}32 \\
\text { (15t qu } \\
\text { on l }\end{array}$ & & & \\
\hline
\end{tabular}


- Measurements of annual average 2390 u concentrations found in Pueblo Canyon showed the same temporal pattern as locations representative of only worldwide fallout.

- Possible, but generally not statistically significant, differences in individual airborne plutonium concentration measurenents during 6- to 8wk sampling periods during 1976 and 1977 at various locations in Los Alamos apparently were unrelated to proximity to Acid and Pueblo Canyons or to measurements of total airborne particulates.

- Measurements during 1 year (1976) of particularly low worldwide fallout levels permitted a good estimate of the lonq-term maximum potential contribution of resuspension to airborne concentrations of plutonium in Pueblo Canyon. This estimate $\left(3 \mathrm{aCi} / \mathrm{m}^{3}\right)$ is abrut $0.005 \%$ of the appropriate DOE Concentration Guide (CG) or $0.3 \%$ of the proposed EPA derived dir concentration limit.

The most useful data of the $5 \mathrm{yr}$ analyzed came from 1976 when the annual averages of airborne concentrations of $2399 \mathrm{u}$ were about 20 to $25 \%$ of preceding or succeeding years. This enhances the sensitivity of any analysis looking for local effects because any such effects would be a much 1 arger proportion of the total measurement. Two factors contributed to the unusually low year: (1) there was very little downmixing of worldwide fallout. from the stratosphere into the troposphere as usually occurs in the late spring, and (2) there had been no atmospheric nuclear tests since June 1974.

The data on $239 p u$ concentrations measured during 1976 at the sewage treatiment plant in Pueblo Canyon, in Santa Fe, and in Now York are shown in Fig. 11. In general, all three locations display the same pattern throughout the year, in most cases differing by less than the neasurement errors. The data from Santa $F e$ are assumed to represent fallout background for northern New Mexico well beyond any potential influence of Los Al amos operations or resuspension from the canyon areas. During the first and seventh sampling periods (12/12/75 to 2/2/76 and 9/13/76 to $10 / 26 / 76)$, the airborne $239 \mathrm{pu}$ concentration in Pueblo Canyon was higher than at Santa Fe (significant for $\alpha=0.1$ but not for $\alpha=0.05)$ by as much as $2.8 \pm 2.8 \mathrm{aCi} / \mathrm{m}^{3}$ (90\% confidence interval). During the fifth sampling period $(6 / 21 / 76$ to $8 / 2 / 76)$, the measurement in Pueblo Canyon was significantly less than in Santa Fe $(a=0.05)$. However, the monthly geometric mean total particulates as measured in the Los Alamos townsite were higher during months of the second, third, fourth, eighth, and ninth sampling periods, when no significant differences in plutonium concentrations occurred. Thus, there are only marginal differences between airborne concentrations of $239 \mathrm{pu}$ in Pueblo Canyon and worldwide $\mathrm{fall-}$ out levels measured elsewhere. No clear relation exists between airborne concentrations of $239 \mathrm{Pu}$ and atmospheric dust loading. Evaluation of data from other air sampling locations in the LOS ATamos townsite might be questioned because of a presumed greater potential for influence from airborne emissions from operating Los Alamos National Laboratory facilities. Some apparent differences in individual sampling periods may plausibly be 


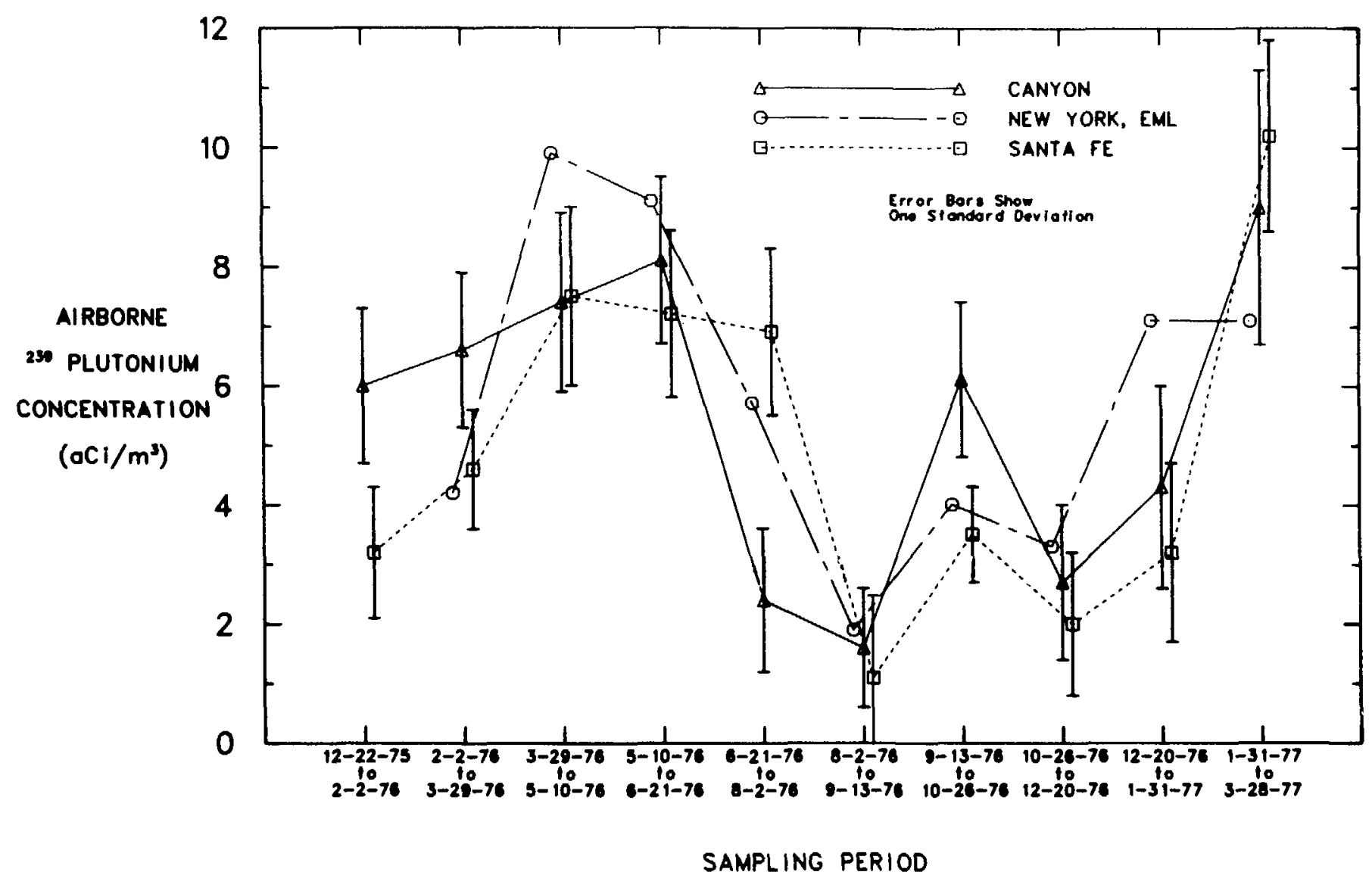

Fig. 11. Concentrations of airborne ${ }^{239 p u}$ at three locations during 1976-1977. 
related to spatial relationships, but there is no consistency in the pattern with time, and the annual averages over several years show no consistent differences related to location. Most important, additional data from many more sampling locations, as reported annually by the Los Alamos National Laboratory environmental monitoring program, have shown no statistically discernible effect on airborne ${ }^{239} \mathrm{Pu}$ concentrations outside the Los Alamos National Laboratory site.

The 1976 data are the soundest bases for an estimate of the maximum effect of sediment and soil resuspension on the airborne concentrations of ${ }^{239} \mathrm{pu}$ in Pueblo Canyon. In addition to the very low worldwide fallout, 1976 was somewhat drier than average (total precipitation ahout $76 \%$ of long-term average), and the annual geometric mean of suspended airborne particulates was slinht ly higher than normal $\left(37.6 \mu \mathrm{g} / \mathrm{m}^{3}\right.$ compared to $\left.35 \mu \mathrm{g} / \mathrm{m}^{3}\right)$. These conditions all would be expected to maximize resuspension. The largest increment above worldwide fallout in $239 \mathrm{pu}$ concentration measured during the year was $2.8 \mathrm{aCi} / \mathrm{m}^{3}$ in Pueblo Canyon (as compared to Santa Fe). This value, rounded to $3 \mathrm{aCi} / \mathrm{m}^{3}$, was used in subsequent analyses as the upper bound on the average increment of ${ }^{239} \mathrm{pu}$ airborne concentration that could be expected over a typical year.

The likely maximum short-term concentration of airborne ${ }^{239} \mathrm{pu}$ in Pueblo Canyon was based on one anomalous measurement that occurred during the last quarter of 1977 . The value was $166 \mathrm{aCi} / \mathrm{m}^{3}$, about 5 to 10 times greater than any other Los Alamos National Laboratory station measured during the same period, and was 2 to 3 times greater than measured during previous sampling periods in 1977. All stations measured higher concentrations in 1977 than in 1976 because there were fallout contributions from spring mixing as well as from three atmospheric nuclear tests by the Peoples Republic of China, two of which took place late in 1976 and one in september of 1977. The spatial and temporal variation in measurements was much larger because of these inputs. A final interpretive factor is that the geometric mean airborne particulate concentration during the last quarter was lower than any previous quarter of the year, suggesting that contributions from resuspension were minimized. Despite these contributing uncertainties, the value (rounded to $170 \mathrm{aCi} / \mathrm{m}^{3}$ ) was taken as a likely maximum short-term concentration of airborne $239 \mathrm{pu}$ that might be expected in Pueblo Canyon.

\subsubsection{Theoretical Estimates. A theoretical model was applied} as another approach to resuspension and as a means of estimating the contribution of resuspension in other parts of the canyon system where no direct measurements were available. The mass loading model was selected because of conceptual simplicity. Estimated airborne concentrations of radioactivity are calculated as the product of the mass concentration of particulates in the air and the activity concentration of radioactivity on the soil. Refinements were included to account for the observed higher concentrations on the smaller, more-resuspendible particles (enrichment factor) and for the small 
proportion of the area containing residual radioactivity along the channels (area modification). Details of the assumptions and calculations are presented in Ref. 1. The enrichment factor was calculated using actual data on activity fractions for different particle size increments from previous radioecology studies in the Los Alamos canyons and the method described in Ref. 37. Soil and sediment concentrations were taken to be the arithmetic means for the various channel and bank components of the canyon segments, with some adjustment to account for slightly higher concentrations occurring in the top $1-\mathrm{cm}$ layer. The area modification was taken to be the ratio of the channel and bank area considered to contain residual radioactivity to the horizontal projection of the canyon area containing the segment. The annual geometric mean particulate mass loading observed in the Los Alamos townsite, $35 \mu \mathrm{g} / \mathrm{m}^{3}$, was used as representative of the area.

Table XIV presents estimates of incremental airborne $239 \mathrm{pu}$ concentratiors attributable to resuspension as calculated from both the actual measurements and the mass loading model. The range of annual average concentrations of ${ }^{2}{ }^{\mathrm{B}} \mathrm{Pu}$ measured in Sant a $\mathrm{Fe}$ is included at the bottom of the $\mathrm{tab}$ le for comparative purposes. The other columns qive the relation of the estiinated concentration increments and background to the DOE CG and to the proposed EPA derived concentration limit. The DOE CG $\left(60000 \mathrm{aCi} / \mathrm{m}^{3}\right)$ is that for $23{ }^{3} \mathrm{pu}$ in Uncontrolled Areas, that is, accessible to the public, with continuous orcupancy, and the lung is considered the critical organ. The EPA value $\left(1000 \mathrm{aCi} / \mathrm{m}^{3}\right)$ is given in its proposed federal quidance as a derived air concentration that can reasonably be predicted to result in dose rates less than the guidance recommendations. The proposed EPA recommendations "... are for quidance on possible remedial actions for the protection of the public health in instances of presently existing contanination..." 38 Most of the estimated annual increments are in the same range as worldwide fallout observed in recent years. The exception is the estimate for Acid Canyon, which is about 4.5 times the $5-y r$ average for fallout. The estimated maximum short-terin value for Pueblo Canyon is about 10 times the 5 -yr average.

The activity ratios from Table XII may be applied to these estimated $239 \mathrm{pu}$ concentrations to obtain estimates of other transuranics. As the proposed EPA derived limit applies to transuranic alpha activity, only the alpha portion of the $24 \mathrm{P} u$ activity should be counted. The total transuranic alpha airborne activity would thus be estimated as 1.13 times, or 13\% more than the $239 \mathrm{pu}$ value for current conditions.

4.7.3 External Penetrating Radiation. Radioactivity on soils and sediments can contribute to radiation doses by the emission of gamma and $x$ rays. The potential increments of such external radiation that could be attributed to residual radioactivity were addressed in this study by measurements in the environment and by theoretical calculation. 
Measurements were made during the first quarter of 1978 by thermoluminescent dosimeters (TLDS) placed at 20 locations in the vicinity of the treatment plant site and along the different canyon bottom segments (Ref.

1). These measurements represented total doses without discrimination between the contribution from the residual radioactivity and that from natural cosmic and terrestrial sources. Accordingly, they can be compared to measurements made in areas representing only natural sources and to estimates of potential residual radioactivity contributions. Such estimates are subject to considerable uncertainty because of large temporal and spatial variaticn in natural background.

Natural background external penetrating radiation variations are well documented in the LoS Alamos area. Most of the variation is due to differences in the terrestrial component because the cosinic component is almost entirely determined by elevation above sea level. In the Los Alamos area, the cosinic contribution is about $60 \mathrm{mrem} / \mathrm{yr}$, or about $5.3 \mathrm{\mu rem} / \mathrm{h}$. The terrestrial component, on the other hand, ranges from about 30 to $90 \mathrm{mrem} / \mathrm{yr}$, or about 3 to $10 \mathrm{urem} / \mathrm{h}$, depending on time and location. The variety of geologic formations with different amounts of natural radioactive elements (principally potassium and the uranium and thorium chains) determines most of this range. Temporal differences, largely associated with soil moisture and snow cover, that affect the accumulation of natural radon daughters often amount to as much as $\pm 25 \%$ from one quarter to the next at a given location. These geologic and temporal variations in the terrestrial component resulted in total quarterly dose measurements for the 12-station perimeter group of the Los Alamos National Laboratory routine monitoring progran ranging from $9.7 \mu r e m / h$ to $17.4 \mu \mathrm{reh} / \mathrm{h}$ between 1976 and 1978. These stations are located on the mesas in the townsite and at other places adjacent to the Los Alamos National Laboratory boundary.

During the first quarter of 1978, the perimeter group measured an aver. age of $12 \mathrm{urem} / \mathrm{h}$, slightly lower than the $4-y \mathrm{r}$ average of $13.4 \mathrm{urem} / \mathrm{h}$, as shown in Table XV. The TLO measurements in the four canyon areas averaged 1: to $19 \mu \mathrm{rm} / \mathrm{h}$. Individual measurements contributing to the averages had $95 \%$ confidence intervals of \pm 10 to $17 \%$, with the implication that the accuracy of the means cannot be much better in spite of the small standard deviations of the means. The apparent differences of 4 to 7 urem/h for middle Dueblo Canyon and Acid Canyon are probably due largely to natural circumstances, different geological formations, and a much narrower, steeper canyon geometry resulting in a larger proportionate terrestrial dose than in the wider canyon segments or on mesa tops. At the site of the former waste treatment $p^{1}$ ant, the apparent difference is due primarily to measurements made in sinall areas in the vicinity of the untreated waste outfall and the vehicle decontamination facility, where maximum levels of surface residual radioactivity were found (Fig. 5). 


\section{l., : 10}

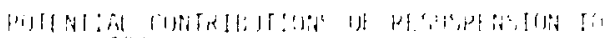

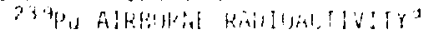

\begin{tabular}{|c|c|c|c|}
\hline & 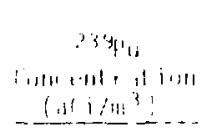 & 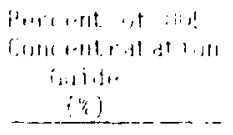 & 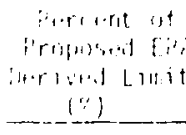 \\
\hline \multicolumn{4}{|c|}{ 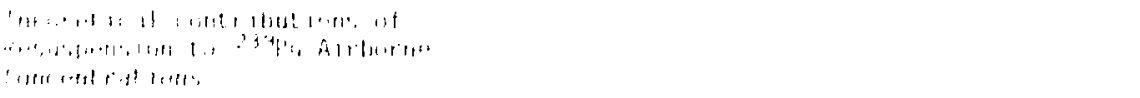 } \\
\hline 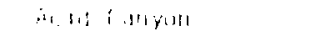 & 11 & 11.1 & 7 \\
\hline 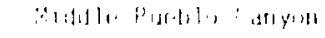 & $M_{3}$ & 0.114 & $\therefore h$ \\
\hline \multicolumn{4}{|c|}{ 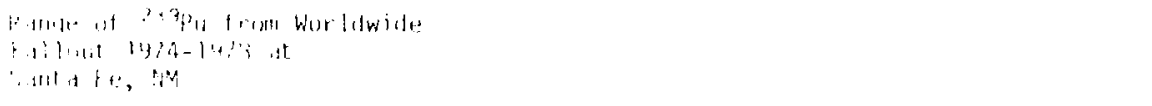 } \\
\hline aw ilyinj & 3.8 & 11.006 & i). 4 \\
\hline 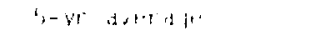 & 31 & 11.113 & 1.6 \\
\hline $1: 411 \quad(11 / 9)$ & $\therefore$ & 6.114 & $\because 4$ \\
\hline
\end{tabular}

Trini $x$

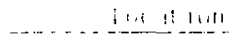

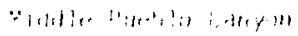

ate i.l 1. stiyind

in-ith +11 .

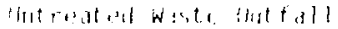

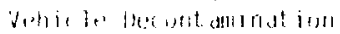

Fatility

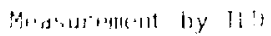

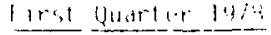

$$
\begin{aligned}
& 16+1 \\
& 19+5 \\
& 19+3 \\
& 16-13 \\
& 27-26
\end{aligned}
$$

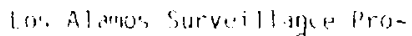

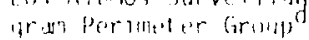

biect indarter 1978

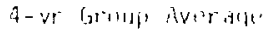

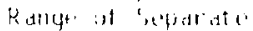

St ation Values,

Token trum Ret. 1.

bCusium-137 main contributar.

Anericibil-24] and 13 CS main contributors.

dot affected by Los Alanis operations.
$1 ?+1$

$13.4+1$

$9.1-1.4 .4$

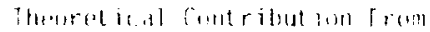

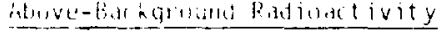

$$
\begin{array}{r}
11.113 \\
1.1^{11}
\end{array}
$$$$
51^{6} \text { (maximum) }
$$$$
4 u^{h} \text { (maximum) }
$$ 
Significant support for these conclusions comes from the theoretically calculated contributions to be expected from the average measured concentrations of radioditivity on the sediments and soils in different strata. Mose rates from above-backyruund concentrations were calculated for ${ }^{13} \mathrm{C} C,{ }^{2} 3^{4} \mathrm{U}$, $238,239 \mathrm{Pu}$, and ${ }^{241} \mathrm{Am}$. The method assumed doses were from an infinite plane, with the radioactivity distributed vertically, and accounted for absorption and scattering in the soil. I The estimated total contributions to doses from these isotopes are presented in Table XIII. The estimated contributions in the canyons range from less than $0.01 \mathrm{urem} / \mathrm{h}$ in middle Pueblo Canyon to 1.1 $\mu \mathrm{rem} / \mathrm{h}$ in Acid Canyon. These calculated values are compatible with and support the TLO measurements and interpretation of importance of variations from natural factors.

The highest estimates of dose contributions from residual radioactivity in the soil were based on measurements of concentrations in the small areas with the highest levels of radioactivity. In the vicinity of the untreated waste outfall, the estimate of $50 \mathrm{\mu rem} / \mathrm{h}$ results mainly from $24 \mathrm{Auin}_{\mathrm{And}}{ }^{13} \mathrm{Cs}$. The infinite plane assumption obviously overstates the estimate because the maximum concentrations occur in areas wiih dimensions on the order of tens of centimeters. Similarly, in the vicinity of the vehicle decontamination $f a c i-$ lity, where the maximum residual radioactivity occurs in areas of a few meters, the $40 \mu \mathrm{rem} / \mathrm{h}$ estimate also is overstated.

During the course of the field work, miny measurements were made with portable instruments. The readings observed with the instruinents were compatible with these interpretations and the TLD measurements. Because of different energy responses, the readings from such instruments cannot be directly interpreted as dose estimates. 1 The purpose of the instrumental surveys was to increase the confidence that no major areas of activity were overlooked.

\subsection{ENVIRONMENTAL CONSEQUENCES}

\subsection{Alternative I--Minimal Action}

5.1.1 Radiological Consequences. There will be no cleanup under this alternative. The radiological risks and radiological conditions, as described in Sections 2.2 and 4.7, respectively, will remain the same. However, the likelihood of exposure to surface residual radioactivity exceeding the proposed criteria will be effectively eliminated by fencing the areas where it exists.

5.1.2 Ecological Consequences. Ecological consequences associated with this alternative will be minimal. Some disturbance will be associated with the fence installation, but this should have little long-term impact on the area, because it is naturally rather barren and rocky. No trees need be disturbed, only the sparse herbaceous and shrubby vegetation. The fence will restrict large animal movement into the 0.45 hectare enclosed plot, but large 
animal movement in this area is minimal anyway, if not nonexistent, because of its location in the middle of the Los Alamos townsite. No endangered species will be affected, because access to the area is not through Pueblo Canyon where the peregrine falcons and perhaps the Jemez Mountain salamander are found. Only temporary alteration of the landscape will occur, and actions associated with the fence installation will not increase erosion potential. No ecoloqical impact on lower Acid Canyon and middle Pueblo Canyon will result from this alternative.

5.1.3 Land Use Impacts. Fencing the area around the head of Acid Canyon will not affect the land use potential because this part of the site is rocky and steep. Recreational use of this area is negligible. The only portion of the site suitable for any kind of a huilding is the former waste treatment facility location where construction would be difficult because of the metal and concrete debris within the landfill (Sec. 4.1.1). This location is outside of the proposed fence and is used by the County as a landfill area. Alternative I does not affect the land use potential of lower Acid Canyon or middle Pueblo canyon. The most likely use of these canyons is fur recreational purposes, as discussed in Sec. 4.1, because they are not suitable for residential development.

5.1.4 Socioeconomic Effects. No direct demographic, institutional, or archaeological effects are associated with this alternative. The 0.45 -hectare plot to be fenced is not in an area associated with any archaeological ruins.

The economic effect will be negligible. Ford, Bacon \& Davis Utah estimated that acquisition of the land and fencing could be completed by a crew of four in 10 to 1 ? days at a cost of $\$ 96,000 .{ }^{2}$ This cost may he an underestimation because of the extremely rugged nature of the area to be fenced and the inflated cost of 1 and in Los Alamos Canyon, but, nevertheless, it represents only a sinall economic inpact. If the Zia Company, a private company under contract to DOE in LOS Alamos, were to perform the cleanup, it would represent about $0.15 \%$ of their annual budget and less than $0.015 \%$ of total annual company man hours.

5.1.5 Risk to Individual Health and Safety. The risk associated with installing the fence is negligible, even considering the rugged terrain that the fence traverses. The radiological risk to the fencing crew also is negligible because of the low level of radioactivity present and the short time required for fence installation. In addition, the fencing crew will not be working directly in the small areas where radioactivity exceeds the proposed criteria. After fencing, radiological risk to recreational users of either the mesa top area at the head of Acid Canyon or of Acid/middle Pueblo Canyon remains as discussed in Sec. 2.2. 


\subsection{Alternative II--Remedial Action (Preferred Alternative)}

5.2.1 Radiological Consequences. Only two small areas, about 0.2 hectare in extent, will be affected by this alternative. Removal of the soil containing residual radioactivity from the former treatment $\mathrm{plant}$ site will reduce the potential dose and risk associated with it. Lower Acid Canyon and middle Pueblo Canyon will remain as discussed in Secs. 2.2 and 4.7. The reduced risk in cleanup areas, along with risks to cleanup workers, truck drivers, and to the general public in the event of an accident en route to the waste disposal site, is discussed in Sec. 5.?.5 on "Risk to Individual Health and Safety."

5.2.2 Ecological Consequences. About 0.2 hectare of surface area will be impacted directly by the cleanup operation. Some additional impact will result from the movement of vehicles to the cleanup sites. However, this will be a minimal additional impact considering the short distance from the main road and the already disturbed landfill area, especially if the existing fence is removed to provide easier access to the former untreated waste outfall site west of Acid Canyon.

The amount of vegetation that will be removed is small because the area is rather barren, rocky, and sparsely vegetated. Removal of only a few large trees should be necessary. Primarily, only herbaceous vegetation and shrubs should be affected, although some root damage to surrounding large trees could occur. The likelihood of any plant protected by state law ( $\mathrm{Sec}$. 4.6.2.2) existing on this particular small plot of ground is very small. The peregrine falcons in Pueblo Canyon are not threatened, nor are any Jemez Mountain salamanders that may reside there, because access to the cleanup areas is by way of Canyon Drive on the mesa top.

The Ford, Bacon \& Davis Utah engineering evaluation called for replacement of the excavated soil and revegetation of the impacted area. However, any attempt to do so would probably be wasted effort. Because the area is rocky and steep, any soi 1 and seed used in a revegetation attempt would prob$a b l y$ wash down the canyon with the first rainstorm. Sparseness of existing vegetation indicates that allowing natural succession to re-establish the vegetation is the most logical approach. In addition, no revegetation is being undertaken in the inmediately adjacent active landfill area. Frosion potential may be slight?y increased in the short term as a result of the cleanup action, but any erosive effect should be small because of the shallow soil depth at the site.

The amount of excavated soil requiring disposal is estimated to be about $230 \mathrm{~m}^{3}$ (Ref. 2). This is a relatively small quantity and should have a negligible impact on operations at the radioactive solid waste disposal site (TA54), amounting to about $5 \%$ of current annual operation. 
5.2.3 Land Use Impacts. The cleanup alternative will not affect contirued use of lower Acid Canyon and middle Pueblo Canyon as recreational areas (Sec. 4.1). The effect on the area around the head of Acid Canyon will be negligible because this terrain is rocky and rough. The only portion of the mesa top at the former TA-45 site suitable for construction is the site of the old treatment plant itself. This area, currently used by Los Alamos County for landfill, will not be affected by the cleanup action. As discussed in Ser. 5.1.3, construction there would be difficult because of the metal and concrete debris within the landill1. Aesthetic effects beyond the cleanup operation itself will be minimal because of the location of the site, which is between a county landfill and a County equipment storage yard.

5.2.4 Socioeconomic Effects. No direct denographic, institutional, or archaeological effects are associated with this alternative. The sinall area around the head of Acid Canyun affected by the cleanup operation contains no archaeological ruins.

The economic effect associated with the cleanup will be small. The cleanup operation is estimated to require 10 to 12 days by a crew of six at a cost of $\$ 55,500.2$ This does not include the cost of backfill and revegetation. The cost of backfill and revegetation was subtracted from the Ford, Bacon \& Davis lJtah estimate because it seems unnecessary and also probably is futile (Sec. 5.2.2). If the cleanup operation were carried out by the $7 i$ a Company, it would represent about $0.1 \%$ of their annual budget and less than $0.02 \%$ of total annual company man-hours.

Transport of soil containing residual radioactivity to TA-54 should have a neqliqible impact on local traffic if it is scheduled to avoid peak commuter traffic hours. Two hundred and thirty cubic meters of soil represent 40 to 45 truckloads of material to be transported from the former TA-45 site to TA-54. Compared to an average daily weekday traffic load of 8500 to 9500 trips (one-way) (Section 4.1.4), this is insignificant. With proper precautions, closure of Diamond Drive and Pajarito Road should not be necessary (Sec. 4.1.4).

5.2.5 Risk to Individual Health and Safety. As a result of cleanup activities, cleanup workers, truck drivers, and the general public may receive some radiation dose. The maximum incremental lifetime risks of dying froin cancer as a result of these doses were estimated for these three groups. These risks are summarized in Table II.

Cleanup workers would incur an additional lifetime risk of bone cancer mortality of $3.4 \times 10^{-7}$ (1 chance in 1200000$)$. This is the highest risk encountered among these groups. For comparison, the lifetime risk of cancer mortality from a 1-yr exposure to natural background radiation is $1.5 \times 10^{-5}$ (15 chances in 1000000$)$. The risk for $50 \mathrm{yr}$ of exposure is $8 \times 10^{-4}(8$ chances in 10 000). 
5.3.1 Radiological Consequences. If no fencing or cleanup action is undertaken, radiological risks and conditions will remain the same as discussed in Sections 2.2 and 4.7 .

5.3.2 Ecological Consequences. No new ecological consequences are associated with the no-action alternative. No endangered species will be threatened. No further alteration of the 1 andscape will occur. Conditions will remain the same as discussed in Secs. 4.3 and 4.6 .

5.3.3 Land Use Impacts. The use of lower Acid Canyon and iniddle Pueblo Canyon as recreational areas (Sec. 4.1) will not be affected. The present use of the former treatment plant site as a landfill will continue. Location of a building there in the future is a possibility because the site is level. However, construction would be difficult because of metal and concrete debris within the landfill (Sec. 4.1.1). Should this occur, there will then be greater potential for exposure of the building occupants to the surface residual radioactivity around the head of the adjacent Acid Canyon.

5.3.4 Socioeconomic Effects. No direct demographic, economic, institutional, archaeological, or other socioeconomic effect will occur under the no-action alternative.

5.3.5 Risk to Individual Health and Safety. There will be no human risk from remedial actions because none are occurring. Risks to recreational users will remain as discussed in Sec. 2.2.

\section{REFERENCES}

1. Los ATamos National Laboratory, "Radiological Survey of the Site of a Former Radioactive Liquid Waste Treatment Plant (TA-45) and the Effluent Receiving Areas of Acid, Pueblo, and Los Alamos Canyons, Los Alamos, New Mexico," Department of Energy report DOE/EV-0005/30 (May 1981).

2. Ford, Bacon \& Davis Utah Inc., "Engineering Evaluation of the Acid/Pueblo Canyon Site, Los Alamos, New Mexico," Bechtel report 10-0501A-001 (October 1981).

3. International Commission on Radiological Protection, "Limits for Intakes of Radionuclides by Workers," Annals of the ICRP Publication 30, Vol. 2, Number 3/4 (Pergamon Press, New York, 1974).

4. US Energy Research and Development Administration, "A Guide for Environinental Radiological Surveillance at ERDA Installations," Division of Safety, Standards, and Compliance report ERDA 77-24 (March 1977). 
5. G. R. Hoenes and J. K. Soldat, "Age-Specific Radiation Dose Commitnent Factors for One-Year Chronic Intake," US Nuclear Regulatory Commission report NIJREG-0172 (Novenber 1977).

6. US Departinent of Energy, "Environmental Protection, Safety, and Health Protection Program for DOE Operations," Chapter XI, "Requirements for Radiation Protection," DOE 5480.1 (Apri1 1981).

7. A. J. Ahlquist, A. K. Stoker, and L. K. Trocki, "Radiological Survey and Decontamination of the Former Main Technical Area (TA-1) at Los Alanos, New Mexico," Los Alanos Scient ific Laboratory report. LA-6887 (December 1977).

8. US Department of Energy, "Removal of a Contaminated Industrial waste Line, Los Alamos, New Mexico," report No. DOE/EV-0005/14 (April 1979).

9. Internaicional Commission on Radiological Protection, Annals of the ICRP, Publication 26, Vol. 1, Number 3 (Pergamon Press, New York, 1977).

10. US Environinental Protection Agency, "National Einission Standards for Hazardous Air Pollutants; Policy and Procedures for Identifying, Assessing, and Regulating Airborne Substances Posing a Risk of Cancer, "Federa) Requister 44: 58642 (October 10, 1979).

11. 1. W. Healy, "An Exanination of the Pathways from Soil to Man for Plutonium," LoS Alamos Scientific Laboratory report LA-6741-MS (April 1977).

12. J. W. Healy and J. C. Rodgers, "Limits for the Burial of the Department of Energy Transuranic Wastes," Los Alanos Scientific Laboratory report LA-UR-79-100 (January 15, 1979).

13. J. W. Healy, J. C. Rodyers, and C. L. Wienke, "Interim Soil Limits for D\&[) Projects," Los Alamos Scientific Laboratory report LA-UR-79-1865Rev. (September 12, 1979).

14. National Council on Radiation Protection and Measurements, "Basic Radiation Protection Criteria," NCRP report 39 (1971).

15. Los Alamos County Council letter from Roger W. Taylor, Chairman, to William Crismon, Jr., Chief, Technical Programs Branch, Los Alamos Area Office, Department of Energy (January 1?, 1982).

16. Health Division, "Waste Disposal," Los Alamos Scientific Laboratory Health, Safety and Environinent Manual," Chapter 1, Section 7 (October 1979). 
17. M. A. Rogers, "History and Environmental Setting of LASL Near-Surface Land Disposal Facilities for Radioactive Wastes (Areas A, B, C, D, E, F, $G$, and T)," Los Alamos Scientific Laboratory report LA-6848-MS, Vol. I (June 1977).

18. K. A. Balo and J. L. Warren, "Waste Management Site Plan," Los Alamos National Laboratory report LA-IJR-81-3656 (December 1981).

19. Environinental Surveillance Group, "Environmental Surveillance at LoS Al amos During 1980," Los Alamos National Laboratory report LA-8810-ENV (Apri1 1981).

20. Los Alanos Scientific Laboratory, "Final Environnental Impact Statement," Department of Energy report DOE/EIS-0013 (Decenter 1979).

21. W. D. Purtymun and M. N. Maes, "Water Supply at Los Alanos During 1980," Los Al amos National Laboratory report LA-8977-PR (October 1981).

22. Los Alamos National Laboratory internal memorandum from Charlie R. Steen, Archaeological Consult ant, to Roger W. Ferenbaugh, Environimental Surveillance Group, "Archaeological Sites in Pueblo Canyon" (February 22 , 1982).

23. Charlie R. Steen, "Pajarito Plateau Archaeological Survey and Excavations," Los Al amos Scientific Laboratory report LASL-77-4 (May 1977).

24. Department of Energy, Los Alamos Area Office, letter from Gary M. Granere, Acting Area Manager, to the Keeper of the National Register of Historic Places, National Park Service (June 11, 1981).

25. J. W. Nyhan, L. W. Hacker, T. E. Calhoun, and D. L. Young, "Soil Survey of Los Alamos County, New Mexico," Los Al amos Scientific Laboratory report LA-6779-MS (June 1978).

26. Barry W. Burton, "Geologic Evolution of the Jemez Mountains and Their Potential for Future Volcanic Activity," Los Alamos National Laboratory report LA-8795-GEOL (January 1982).

27. Los Alamos National Laboratory internal mernorandum from Roger $W$. Ferenbaugh, Environment al Surveillance Group, to Harry S. Jordan, Associate H-Division Leader, "Air Quality Regulation Review--Summary" (May 7, 1981).

28. 40 CFR 81.421 . 
29. T. S. Foxx and F. D. Tierney, "The Peregrine Falcon Habitat Treatment of the Energency Landing Strip in Pueblo Canyon," Los Alamos National Laboratory report (in press).

30. Los Alamos National Laboratory internal memorandum from T. S. Foxx and G. D. Tierney, Consultants, to Roger W. Ferenbaugh, Environmental Surveillance Group, "Veget at ion of Acid-Pueblo Canyon" (March 29, 1982).

31. T. S. Foxx and G. D. Tierney, "Status of the Flora of the Los Alamos National Environnental Research Park," Los Alamos Scientific Laboratory report LA-81)50-NERP, Vol. I (May 1980).

32. F. R. Miera, Jr., K. V. Bostick, T. E. Hakonson, and J. W. Nyhan, "Biotic Survey of Los Alamos Radioactive Liquid-Effluent Receiving Areas," Los Alamos Scientific Laboratory report LA-6503-MS (January 1977).

33. Environmerital Surveillance Group, "Environmental Surveillance at Los Alamos During 1977," LoS Alamos Scientific Laboratory report LA-7263-MS (April 1978).

34. Environmental Surveillance Group, "Environmental Surveillance at Los Alamos During 1978," Los Alamos Scientific Laboratory report LA-7800-ENV (April 1979).

35. Environmental Surveiliance Group, "Environmental Surveillance at Los Alamos During 1979," Los Alamos Scient if ic Laboratory report LA-8200-ENV (April 1980).

36. Environmental Surveillance Group, "Environmental Surveillance at Los Alamos During 1981," Los Alamos National Lahoratory report LA-9349-ENV (April 1982).

37. US Environmental Protection Agency, "Proposed Guidance on Dose Limits for Persons Exposed to Transuranium Elements in the General Environment," Office of Radiation Programs report EPA 540/4-77-016 (September 1977).

38. US Environsental Protection Agency, "Persons Exposed to Transuranic Elements in the Environment, "Federal Register 42 (230): 60956-60959 (November 30, 1977). 


\section{APPENDIX A \\ DOSE CALCULATIONS FOR TA-45/ACID CANYON CLEANUP}

\subsection{SOIL CONCENTRATIONS IN THE AREAS OF CLEANUP}

Two areas would be cleaned up under Alternative II. These areas, shown in Fig. A-1, have highly variable above-background soil concentrations of $90 \mathrm{Sr}$,

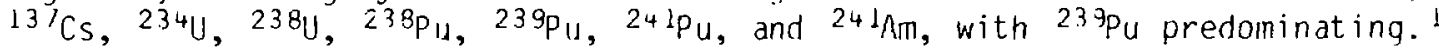
Soil concentrations of $239 \mathrm{pu}$ are included in Fig. A-1 to show the range of concentrations involved. The soil concentrations of all above-background isotopes are presented in Table A-I.

As $c$ an be seen from the table, the radionuclide having the highest. activity is $239 \mathrm{pu}$, for which the soil concentrations range from 0.61 to 163000 $\mathrm{pCi} / \mathrm{g} .{ }^{1}$ Maximum concentrations of total uranium, $238 \mathrm{pu}_{\mathrm{u}}, 24 \mathrm{lpu}$, and $24 \mathrm{Amm}_{\mathrm{Are}} 600$ $\mu \mathrm{g} / \mathrm{g}, 696 \mathrm{pCi} / \mathrm{g}, 14900 \mathrm{pCi} / \mathrm{g}$, and $1200 \mathrm{pCi} / \mathrm{g}$, respectively, and were located in the same area as the highest $239 \mathrm{pu}$ sample near the untreated waste outfall. The. maximum concentrations of ${ }^{90} \mathrm{Sr}(229 \mathrm{pCi} / \mathrm{g})$ and ${ }^{13 /} \mathrm{Cs}(176 \mathrm{pCi} / \mathrm{g})$ were found near the former vehicle decontamination facility.

To estimate doses resulting from cleanup operations, average radionuclide soil concentrations were calculated for the soil to be removed. Most samples in the areas to be excavated were collected in the sections of the untreated waste outfall with the higher activities (Fig. A-l). Sampling density in other areas was smaller. To adjust for this nunrandom distribution of sampling points, an area-weighted average was used to give the best estimate of the radionuclide concentrations present.

The untreated waste outfall area (shown in Fig. 5 of the main text) was divided into two sections, $A$ and $B$, so that the more radioactive material in the northern part (Section A, which encompasses samples 2, 3, 6, 7, 8, 9, and 12) would be treated separately. Sections $A, B$, and $C$, the section to be cleaned up around the former vehicle decontamination facility (Fig. 5, main text), had estimated areas of approximately 90, 60, and $300 \mathrm{~m}^{2}$, respectively. ${ }^{1}$ These areas were used as weights in calculating the overall average radionuclide concentrations in the soil to be excavated. The averages are given in Table A-II.

\subsection{DOSES TO CLEANUP WORKERS}

Doses to cleanup workers were estimated from sampling results of previous cleanup operations performed at the Laboratory. ${ }^{2,3}$ This calculational procedure was chosen because it gives the most realistic estimate of the expected dose. It is based on real data taken from projects similar to the present project. During the present project, dose reduction measures and health physics supervision similar to those for the previous cleanup operations ${ }^{2,3}$ would be applied. 


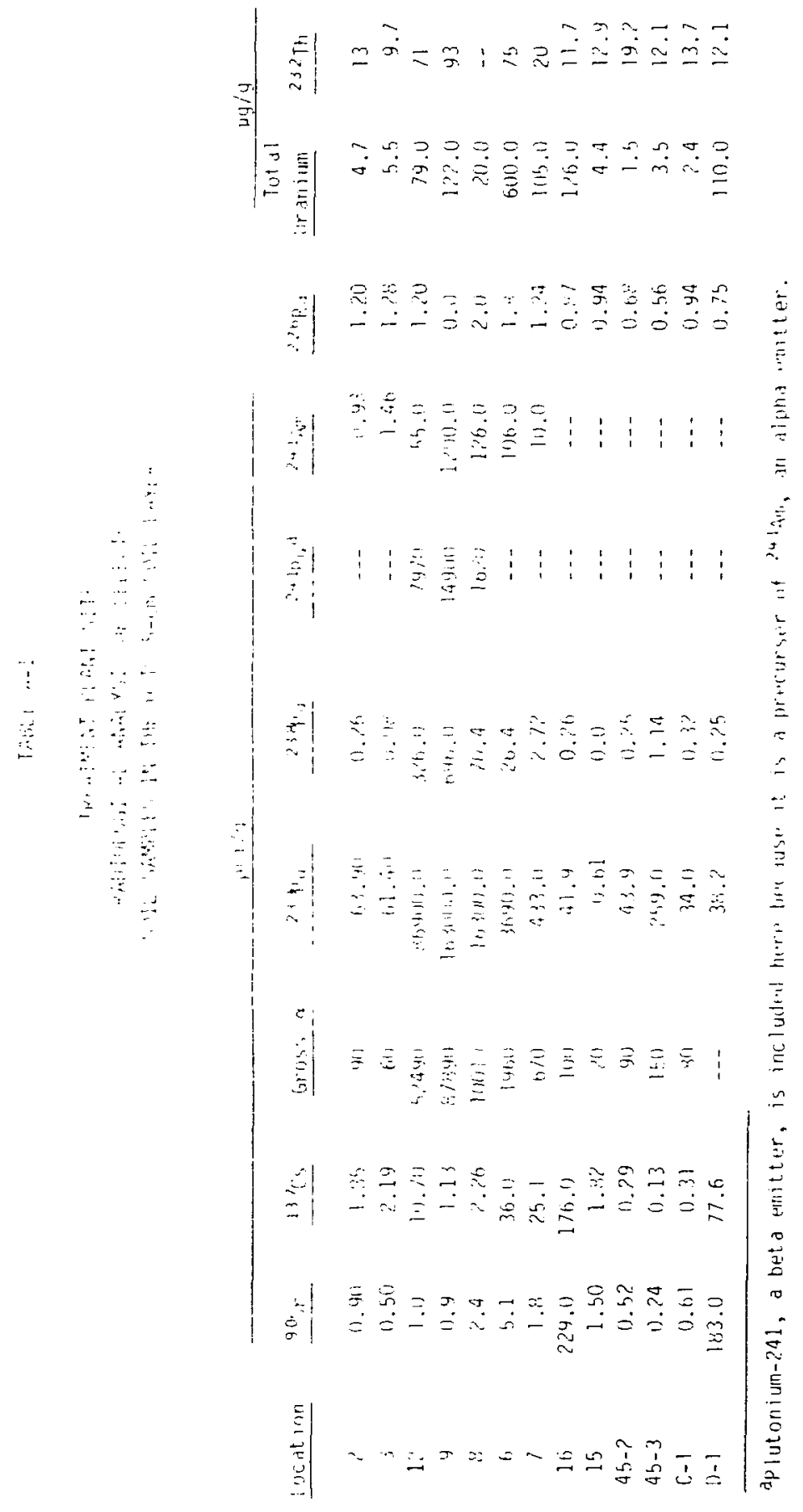




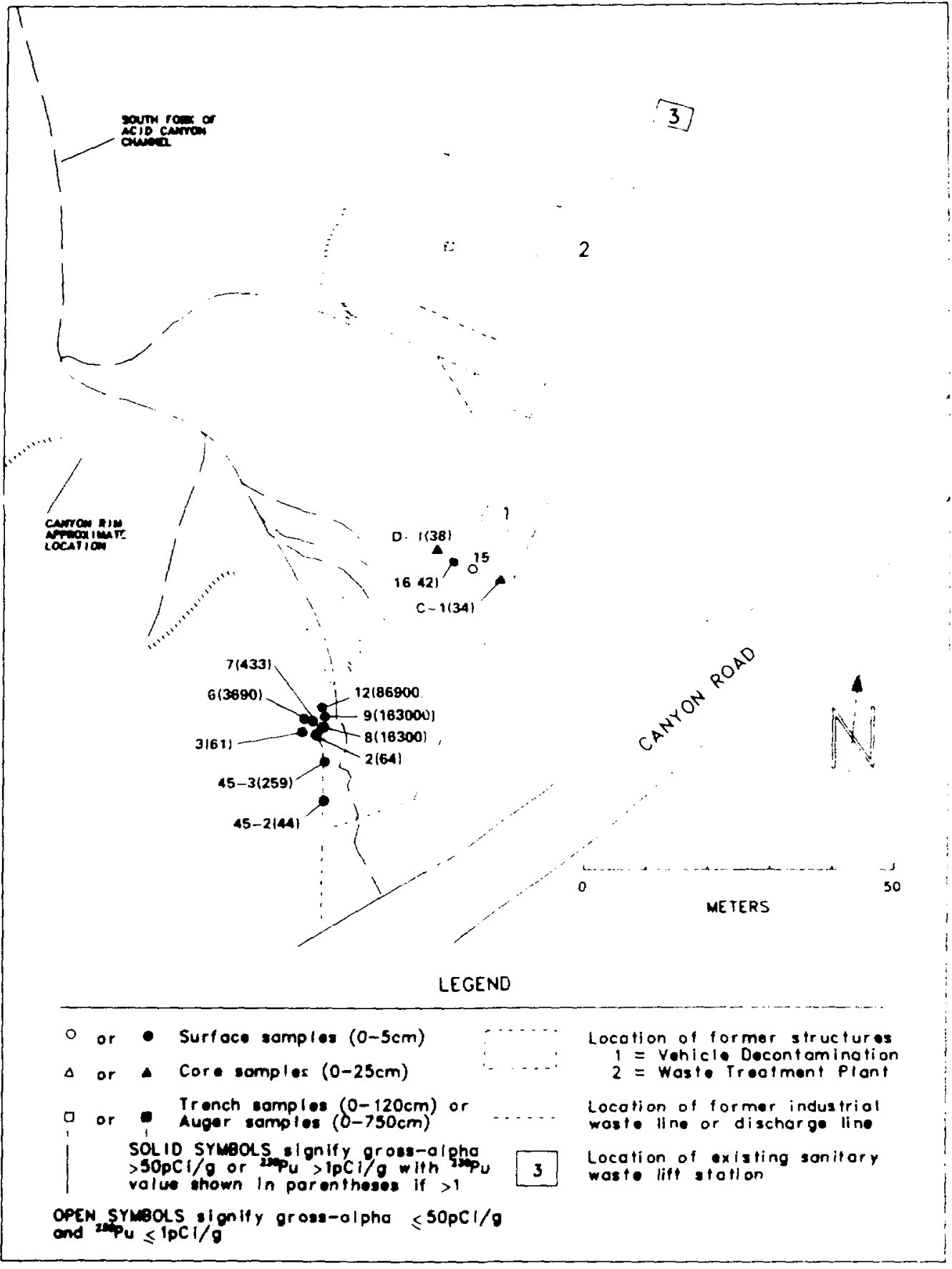

Fig. A-1. Sampling locations and summary results for areas of former treatment plant site to be cleaned up under Alternative II. 
TABLE A-I I

AVERAGE RADIONUCLIDE CONCENTRATIONS IN SOIL ( $\mathrm{pCi} / \mathrm{g})$

IN THE AREAS OF CLEANUP

\begin{tabular}{|c|c|c|c|c|c|c|c|c|}
\hline Section & $90 \mathrm{Sr}$ & ${ }^{13}{ }^{7} \mathrm{Cs}$ & $239 \mathrm{pu}$ & $238 p_{u}$ & $24 \mathrm{LPu}$ & $241_{\mathrm{Am}}$ & $23{ }^{4} U^{a}$ & $238 U$ \\
\hline$A$ & 1.80 & 11.32 & 38600 & 160 & 8200 & 210 & 980 & 45 \\
\hline$B$ & 0.38 & 0.21 & 150 & 0.70 & -- & -- & 18 & 0.83 \\
\hline C & 104 & 64 & 29 & 0.21 & -- & -- & 445 & 20 \\
\hline \multicolumn{9}{|c|}{ Area Weighted } \\
\hline Aver age & 70 & 45 & 7800 & 32 & -- & -- & 500 & 22 \\
\hline
\end{tabular}

aThe ${ }^{234} \mathrm{U}$ is based on the estimate of $7 \mathrm{pCi}$ of excess $234 \mathrm{U} / \mathrm{ug}$ of total uranium (3). 
Past experience at the Laboratory has shown that dose reduction measures have been effective in keeping radiation doses low. These measures include keeping soil wet during excavation to reduce dusting and using respiratory protection equipment, in this case full-face inasks, whenever resuspension of soi? with high levels of residual radioactivity is a possibility.

In the cieantip of the former main technical area (TA-1) in 1975 aria 1376 , elevated levels of 23 pu similar to those found in the Acid/pueblo project wert: encountered.1,2 soil near buildings 5 and De at TA-l had yross-alpha levels, mostly $239 \mathrm{pu}$, in the thousands of $\mathrm{pCi} / \mathrm{q}$. Reported high concentrations incluted a sample with 125 ono pCi/g of $233 \mathrm{pu}, 365 \mathrm{pCi} / \mathrm{g}$ of $23 \% \mathrm{pu}$, and $986 \mathrm{pri} / \mathrm{q}$ of 24 Am. Samples were reported as having gross-alpha activitiss up to 99610 $\mathrm{pCi} / \mathrm{g}$, as measured with a field gross-alpha detector. Some soi i hal alpha activity measured with a phoswich (a portable survey instrument sesigned to detect $x$-ray radiation, from which alpha activity is inferred) greater than 100 oon $\mathrm{pCi} / \mathrm{g} .^{2}$

During the TA-l project, air was sampled throughout the workday in the immediate vicinity of the cleanup operation, and the dir filters were and yzed daily. Of 242 air samples, 33 had positive, long-lived gruss alpina dctivity. The maximum concentration was $3.6 \times 10^{-13}$ uCi/me?

Daily nuse swipes were taken from workers in areas with residual radioactivity, but no xtivity was found in any of the 1705 swipes. A1! workers who might have been exposed to plutonium were given urinalyses. Twenty urinalyscs outside the routine urinalysis nrogran were performed for TA-1 workers. vo urinalyses indicated exposure. ${ }^{2}$

Other radiation protection measures taken at TA-1 inat woult also be used at the Acid/Pueblo cleanup operation would be the wing of persme? ihermluminescent dosimeters to ineasure external penetrating radiation and the use of protective clothing. If a potential for significant airhorne radioactivity exists, full-face masks will be used.

The occupational health physics sampling results from the removal and cleanup of the former acid waste sewer line at the intersection cf Trinity and Dianond Drive in 1977 also were reviewed." Of 40 air samples taken, none haij detectabie gross alpha or gross beta. The lower limits of detection wire $0.7 \%$ of the Radioactivity Concentration Guide (RCG) for $239 \mathrm{Pu}$ and $0.0035 \%$ of the RCG for unknown gross-beta activity. ${ }^{+}$

Doses to clearup workers for the present project, the cleanup of the site of the former waste treatment plant, were estimated using the highest TA-I air sampling result. We used tho conservative assumption that the highest air concentration uf gross-alpha activity measured at TA-1 $\left(3.6 \times 10^{-13} \mathrm{KC} / \mathrm{ml}\right.$, or 0.36 $\mathrm{pCi} / \mathrm{m}^{3}$ ) persisted throughout the $56 \mathrm{~h}$ of Acid-Puebio site preparation and excavation. This airha activity was assumed to be dise to $23 \mathrm{~s}_{\mathrm{u}}$. We assigned 
air concentrations to the uther radionuclides present in the soil by multiplying the $239 \mathrm{p}$ air concentration $\left.10.36 \mathrm{pci} / \mathrm{m}^{3}\right)$ by the ratio of the activity of each rationuclide to that of "'Pu. Ratios were calculated from the average concentrations of the various radionuclides from soil samples collected in the section of the untreated waste outfall area (Ser. A, Fiq. A-1) having the highest comentration of residual radioactivity.

The formul a $\|_{i j}=\left(A C_{j}\right)(B R)(T)\left(O C F_{i j}\right) /(P F)$ was used for $50-y$ r dose comnitment. calrolations,

where?

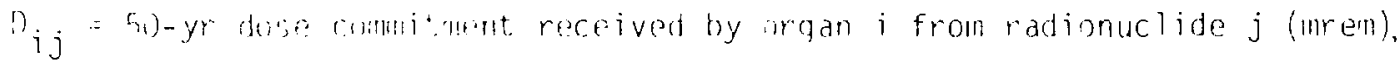

$A C_{j}=$ dir moncentrat im uf radionuc?ide $\left.j(p C i / m)^{3}\right)$,

$B P=0.043 \mathrm{~m}^{3} \mathrm{f}$ inin, the breathing rate typical of an adult doing heavy work, 5

$T=3360$ min $(56 h)$, the estimated length of time needed for cleanup (site preparation and excavation) of the area,

()CF ${ }_{i j}=$ dose conversion factor giving the 50-yr dose commitment (mrem) to araan; due to inha? ation of $1 \mathrm{pCi}$ of radionuclide $\mathrm{j}$ (mrem/pCi), and

$P t=$ protection fartur: = 1 for an individual with no respirator; = 100 for an individual wolring a full face mask. ${ }^{6}$

Fifty-year doce commitments to whole bodv, bone, and lung were calculated for all radinnuclides. Dose conversion factors were taken from Ref. 7 . Doses are presented in Table A-III. The doses were calculated for an individual not wearing a full-face mask $(P F=1)$. This is a conservative assumption because full-face masks will be worn for at least part of the project when the soil having higher concentration is being removed. This would reduce by a factor of 100 the dose received during the time period when a respirator is worn.

\subsection{DOSE. TO A TRIJCK DRIVFR}

Truck drivers wiil spend approximately $11 \%$ of their time at the cleanup site. The romaining time will be spent driving to and from the radioactive waste disposal site $(T A-54)$ and emptying loads of soil at the site.

At the cleanup site, drivers will have the same respiratory protection as the cleanup workers. Consequently, their doses from soil inhalation and exposure to external radiation will be $11 \%$ of that incurred by workers.

While transporting soil to TA-54, drivers will be exposed to external radiation from gamma emitting radionuclides in the soil for approximately $16 \mathrm{~h}$ of the 56-h cleanup operation. We used external radiation dose conversion 


$\frac{50-\text { Yr Dose Commitment (mrem) }}{\text { Bone }}$

Cleanup Workers

Inhalation

External exposure

Total

Truck Drivers
At work site

Driving soil

Total

$\begin{array}{lll}168 & 9.1 & 4.1 \\ \frac{0.38}{169} & \frac{0.38}{9.5} & \frac{0.33}{4.5}\end{array}$

13.4

$\frac{0.44}{19}$

1. 1

$\frac{0.44}{1.5}$

1). $5(1)$

$\frac{0.44}{0.94}$

General Public

Routine operations

Inhalation

External radiation

Accidents

0.24
0.17

56
0.013

0.17

3.0
1). 0059

0.17

1.4

factors, calculated to give the dose at $3 \mathrm{ft}$ above an infinite miformly contaninated half-space, to conservatively estimate the external dose rate in the cab from the load of soil. ${ }^{8}$ Area averaged soil concentrations presented in Table A-II were used in applying these factors. Total estimated $50-y r$ dose commitments to drivers are shown in Table A-III.

\subsection{DOSES TO THE GENERAL PUBLIC}

\subsection{Rout ine Operations}

Inhalation doses to the general public were estimated using the highest reported environmental concentration of $233 \mathrm{pu}$ measured as part of the monitoring for the two previous cleanup operations at TA-1 and Diamond/Trinity Drives, 2,3 discussed in Sec. 2 of this appendix. This concentration was $463 \times 10^{-18}$ $\mu \mathrm{Ci} / \mathrm{ml}$, measured during a 2-wk period during the cleanup of TA-1. The general public was assumed to be exposed to this $239 \mathrm{pu}$ concentration during the entire 7 days of site-preparation and excavation. Air concentrations of $90 \mathrm{Sr},{ }^{13} \mathrm{Cs}$, $234 \mathrm{U}, 238 \mathrm{U}, 238 \mathrm{pu}, 24 \mathrm{pu}$, and $24 \mathrm{Am}$ were derived by multiplying the $239 \mathrm{pu}$ air concentration by the ratio of the activity of each radionuclide to $239 \mathrm{pu}$ activity, as found in the average radionuclide concentrations from the untreated 


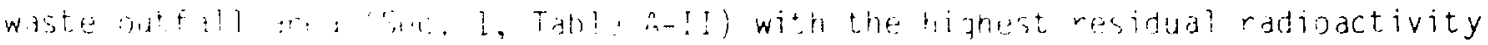

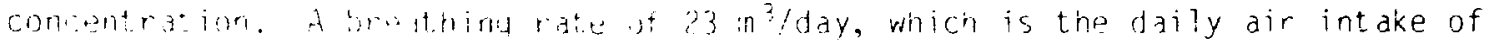
the standarian, "aposidre time of 7 days, and dose conversion factors from

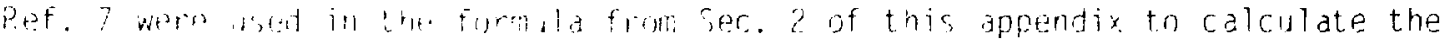
Airs'.

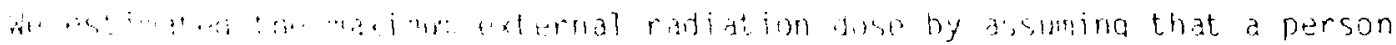

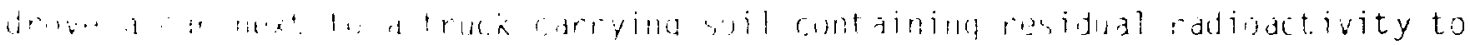

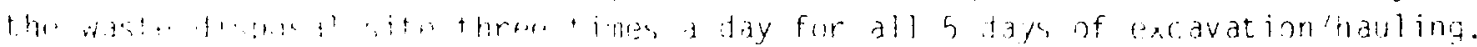

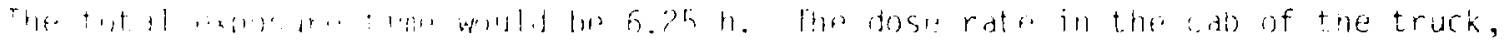

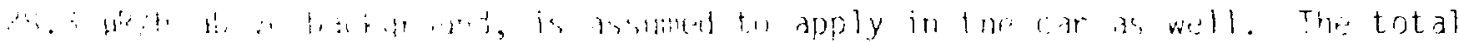

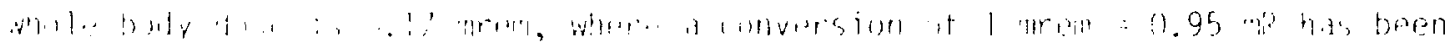
is $\cdots 1$.

A. is $11, \ldots+$

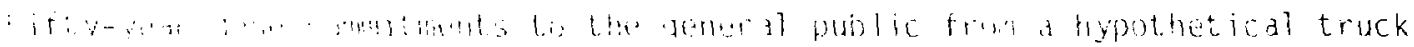

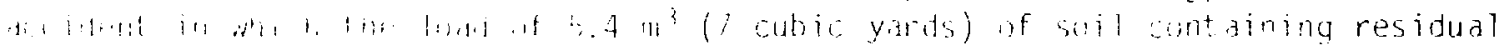

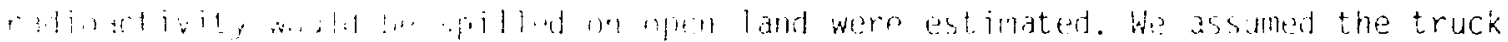

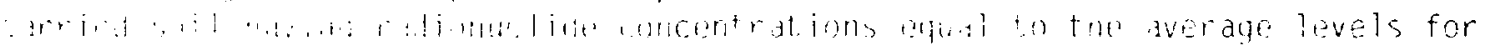

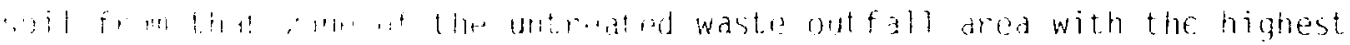

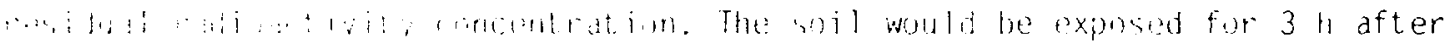

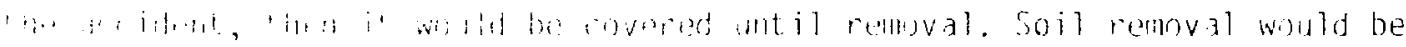

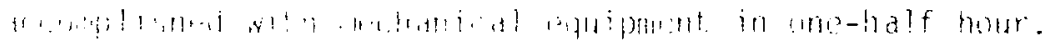

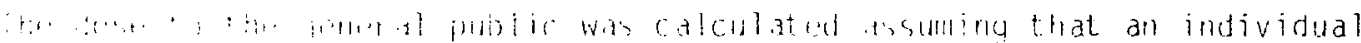

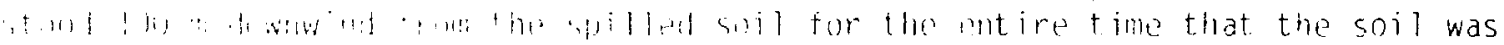

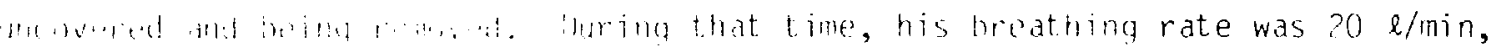

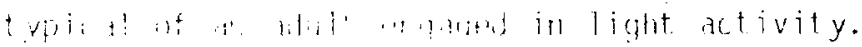

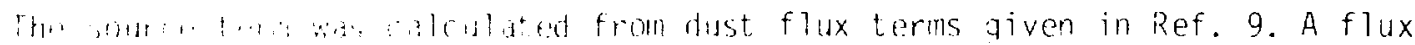

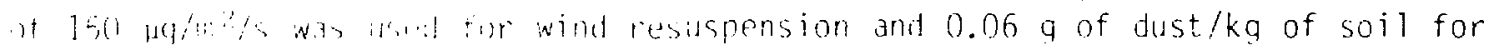

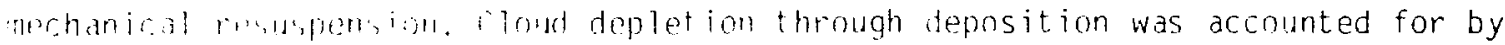
the fallout finction given in hef. 9 for use with the source teras. The spilled

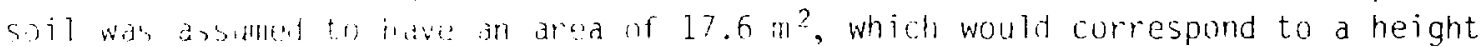
of approxinat aly $0.1 \mathrm{ln}(1 \mathrm{ft})$. As in Ref. 1, an enrichment factor of 2.3 was used to acromet for bur hiqher comentrations of radionuclides on the smaller sizos piaticlis.

Air concentratim were calculated using a standard Gaussian dispersion moiel for plime rol an. A D-wind stahility category and wind speed of $3 \mathrm{~m} / \mathrm{s}$ were ascumed throumbut the semario.

The Lase astimates inclubeid a number of conservative assumptions that would result in an nurestimation of the predicted dose. The exposure time for the maxinally oxpiad ingididal would probaly be much less than $3 \mathrm{~h}$. This is because the spilled ioil would be covered shortly after the accident, eliminatinu dusting frum wind resuspension. In addition, keeping the soil wet, 
and, if necessary, removing the soil with hand shovels rather than heavy equipment would reduce dusting from mechanical resuspension. If the need arose, controlled access areas would be roped off around the spilled soil so that the general public would not be in areas of significant airborne

radioactivity. Another conservative assumption was that the spilled soil was from the section of the cleanup site having the highest concentrations of residual radioactivity. The dose estimates are presented in Table A-III.

\section{REFERENCES}

1. "Radiological Survey of the Site of a Former Radioactive Liquid Wasto Treatiment Plant (TA-45) and the Effluent Receiving Areas of Acid, Pueblo, and Los Alamos Canyons, Los Alamos, New Mexico," IIS Department of Energy report DOE/EV-0005/30 (May 1981).

2. A. J. Ahlquist, A. K. Stoker, and L. K. Trocki, "Radiological Survey and Decontamination of the Former Main Technical Area (TA-1) at Los Alamos, New Mexico," Los Alamos Scientific Laboratory report LA-6887 (December 1977).

3. US Department of Energy, "Removal of a Contaminated Industrial Waste Line, Los Alamos, New Mexico," report DOE/EV-0005/14 (April 1979).

4. US Department of Energy, "Environmental Protection, Safety, and Health Protection Program for DOE Operations," Chapter XI, "Requirements for Radiation Protection," DOE 5480.1 (April 1981).

5. International Commission on Radiological Protection, "Report of the Task Group on Reference Man," ICRP Publication 23 (1975).

5. American National Standards Institute, Inc., "American National Standard Practices for Respiratory Protection," ANSI publication 288.2-1980 (May 1980).

7. G. R. Hoenes and J. K. Soldat, "Age-Specific Radiation Dose Commitment Factors for a One-Year Chronic Intake," US Nuclear Regulatory Commission report NUREG-0172 (November, 1977).

8. H. L. Beck, J. DeCampo, and C. Gogolak, "In Situ Ge(Li) and NaI(TI) GaminaRay Spectrometry," US Health and Safety Laboratory report HASL-258 (September 1972).

9. US Nuclear Regulatory Commission, "Final Generic Environmental Impact Statement on Uranium Miliing," US Nuclear Regulatory Commission report NUREG-0706 (September 1980). 


$$
\begin{aligned}
& \text { APPENAI: B }
\end{aligned}
$$

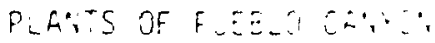

Aracarisiari:

Phuc :5: : a a:

Araranthaneai

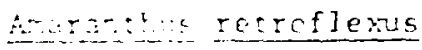

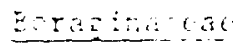

crosiandarai

Laz

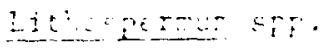

Caciandic

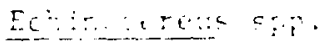

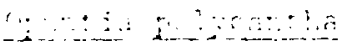

Ca.

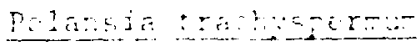

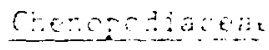

Artan caneserescos

r : an dis iraveolars

Fungodise Exementi

Sajsola k:ald

Cerios:as (Averaceas)

A: enarja Earyfolia

A.rec:isia carruthil

Artemisia dracunculoides

Arterisia friaija

Ar:e-isia ludcviciana

Ar:erisia tridentata

Aster tigelovil

Ascer tespertus

Bahia Cissecta

Brickell1a al1fornica

Chrysopsis villosa

Chrysothamnus nauseosus

Convza canadensis

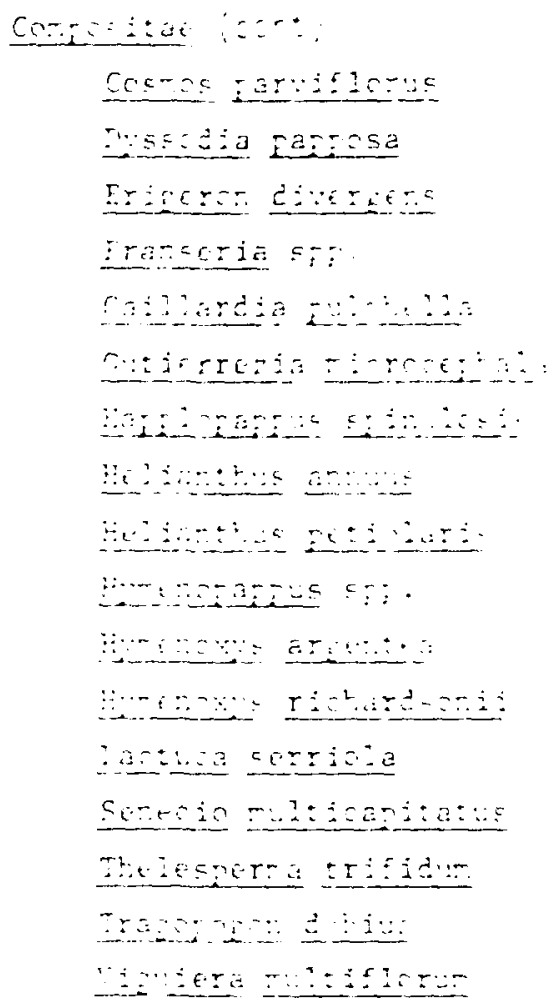

Criaifigae

Iescutairia s:5.

Cuiressacese

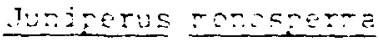

Iurinerus sconuloru

Crreraceae

Carex spp.

Euntorbiaceae

Croton texensis

Euphorbia dentata

Euphorbia serpvilifolia

Fasaceae

Quercus gambelii

guercus undulata 


$$
\text { APPENDIX B (cont) }
$$

Geraniaceae

Erodium circutarium

Geranium caespitosur:

Gramineae (Poaceae)

AErcg:ron desertorum

ieropiron smithid

Andropogon scoparius

Aristida divarica:a

Bouteloua curtipendulu

Bouteloua ericpoda

Boutelcua Eracilis

Brobus spe.

Erome tectoris

Eestuca spp.

Koelaria cristata

huhlerbereia montana

Minroa squarrosa

Orvzopsis hymenoides

Poa spp.

Sitanion hystrlx

Sporobolus contractus

Sperobolus spp.

Hudrophyllaceae

Phacelia spp.

Labiatae

Monarda pectinata

Leguminosae (Fabaceae)

Lupinus caudatus

Fobinfa neomexicana

Vicia americana

Liliaceae

Allium cernuum

Yucca baccata
Loasazeá

Yerizuida Eurila

:ajvazeac

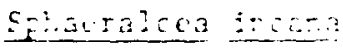

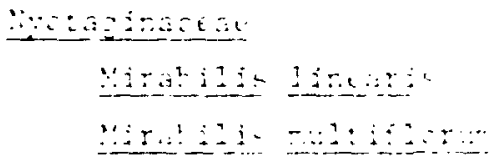

Oesisis

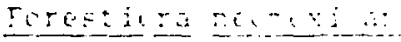

Craseracesc

Conctices ent.

Critangiaseat

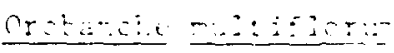

Pinareae

Pinus ed:ijs

Piris nesdires

Piantagiraceat

Plan: Eec Eurs:ii

Poleroniaceat

Gilia azerezata

Gilia longificra

Gilia spp.

Polyzonaceae

Eriogonu- cernum

Ericsonum jamesii

Rurex spp.

Portulacaceae

Portulaca oleracea

Ranunculaceae

Pulsatilla ludoviciana 


$$
\text { APFENOIX E (COA:) }
$$

Rosaccae

Cerccsarf:= mantanus

Fazluzia Jarazoxa

Potentilla spp.

Prunus virginiara, var. molem area

Fisacose

$$
\text { Fte?ca an:as:itolia }
$$

salicactat

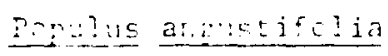

Savisadaceat

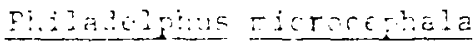

Sercinasiandide

Cas:i]jeja intez:a

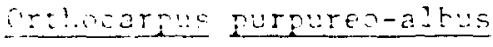

Dens:ara harhatus, var. torro

Yertasen tharsis
$5: 13+3+e_{0}$

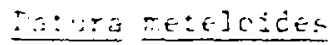

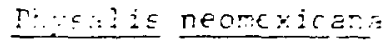

Tartericaceac

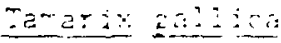

$\because: 1-a c c a$

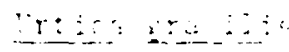

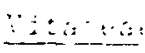

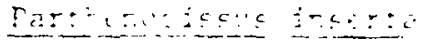




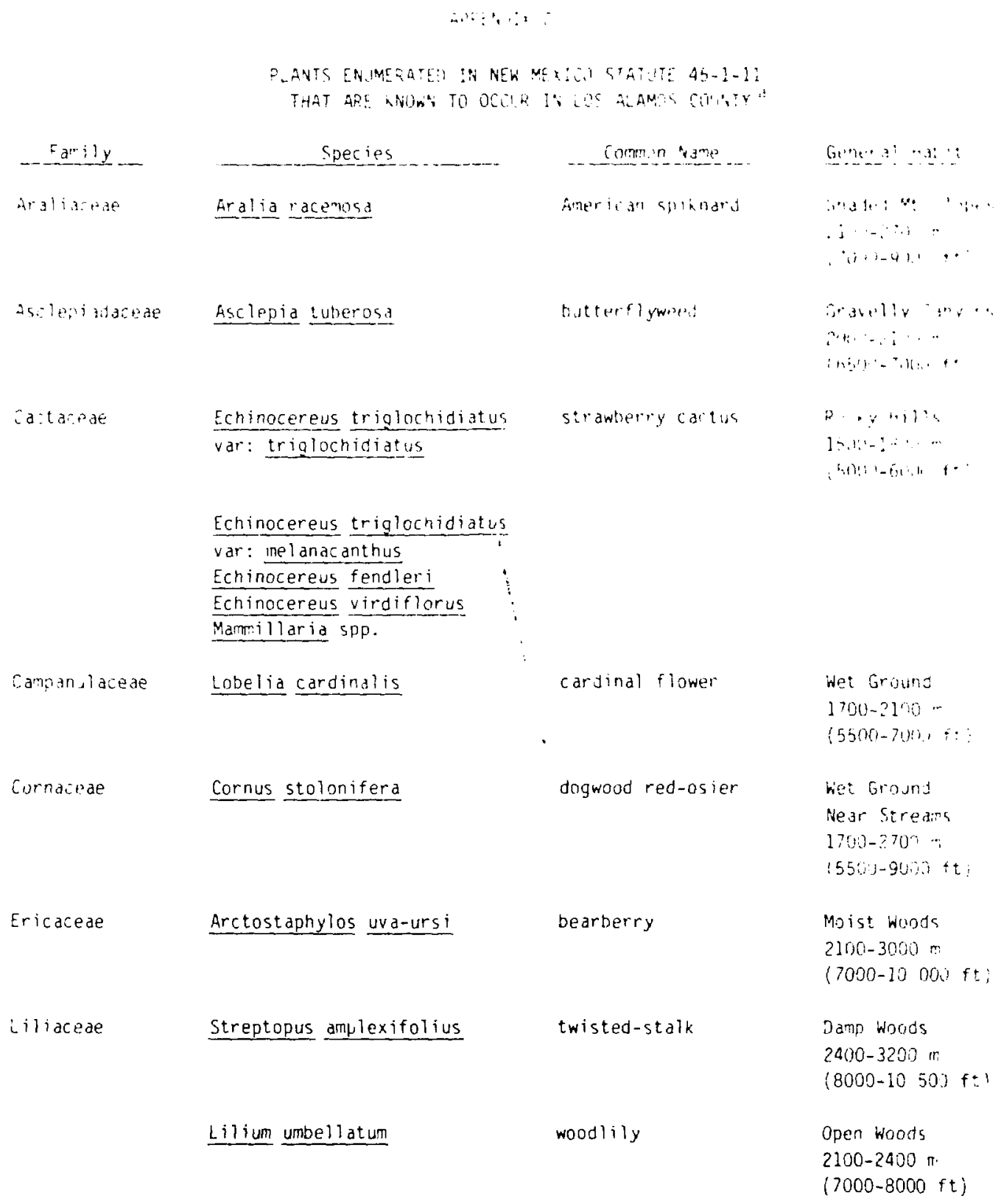

ataken from T. S. Foxx and G. D. Tierney, "Status of the Flora of the Los Alamos Nationa? Environmental Research Park," Los Alamos Scient ific Laboratory report LA-8050-NERP, Vol. I (May 198C). 


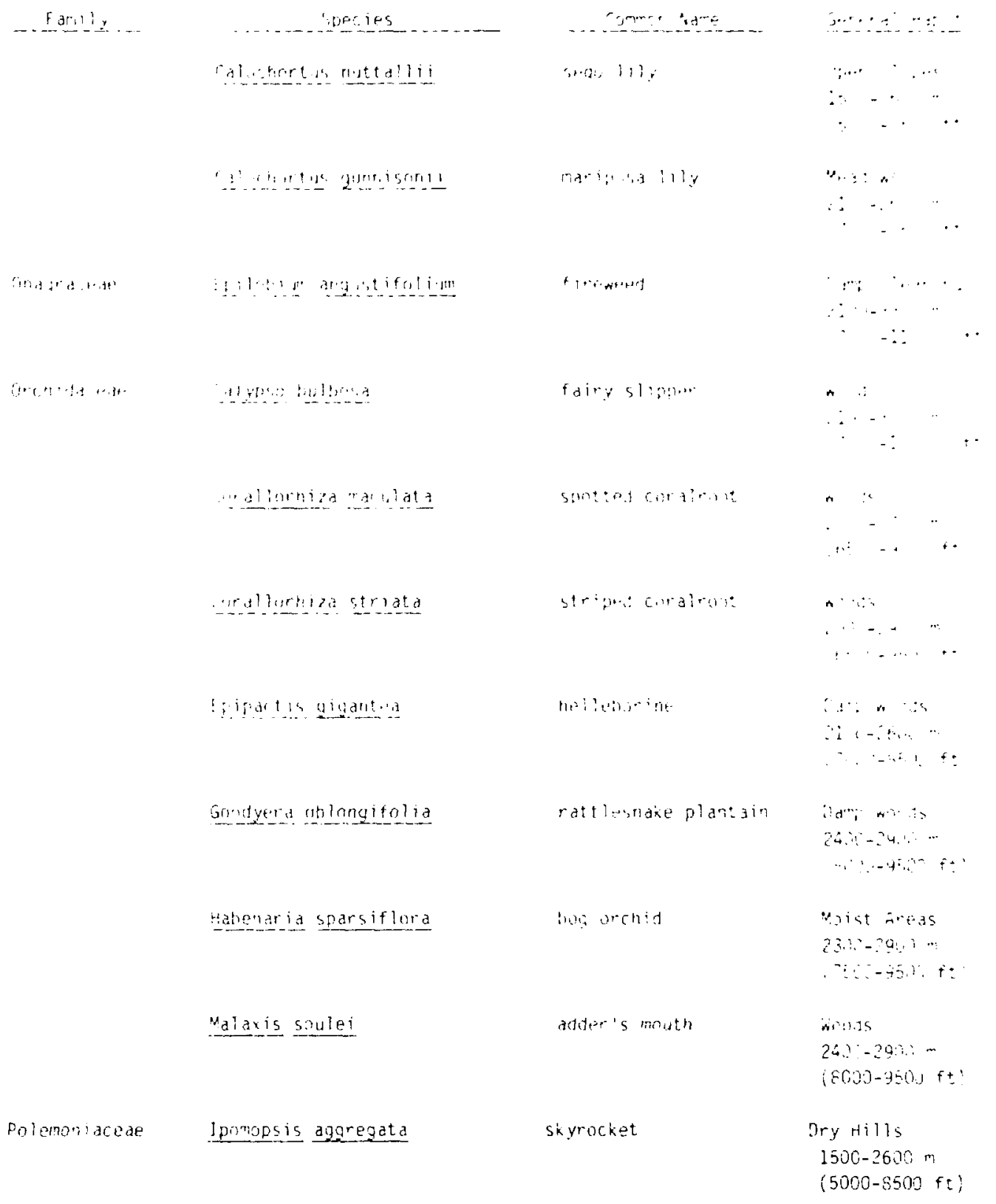




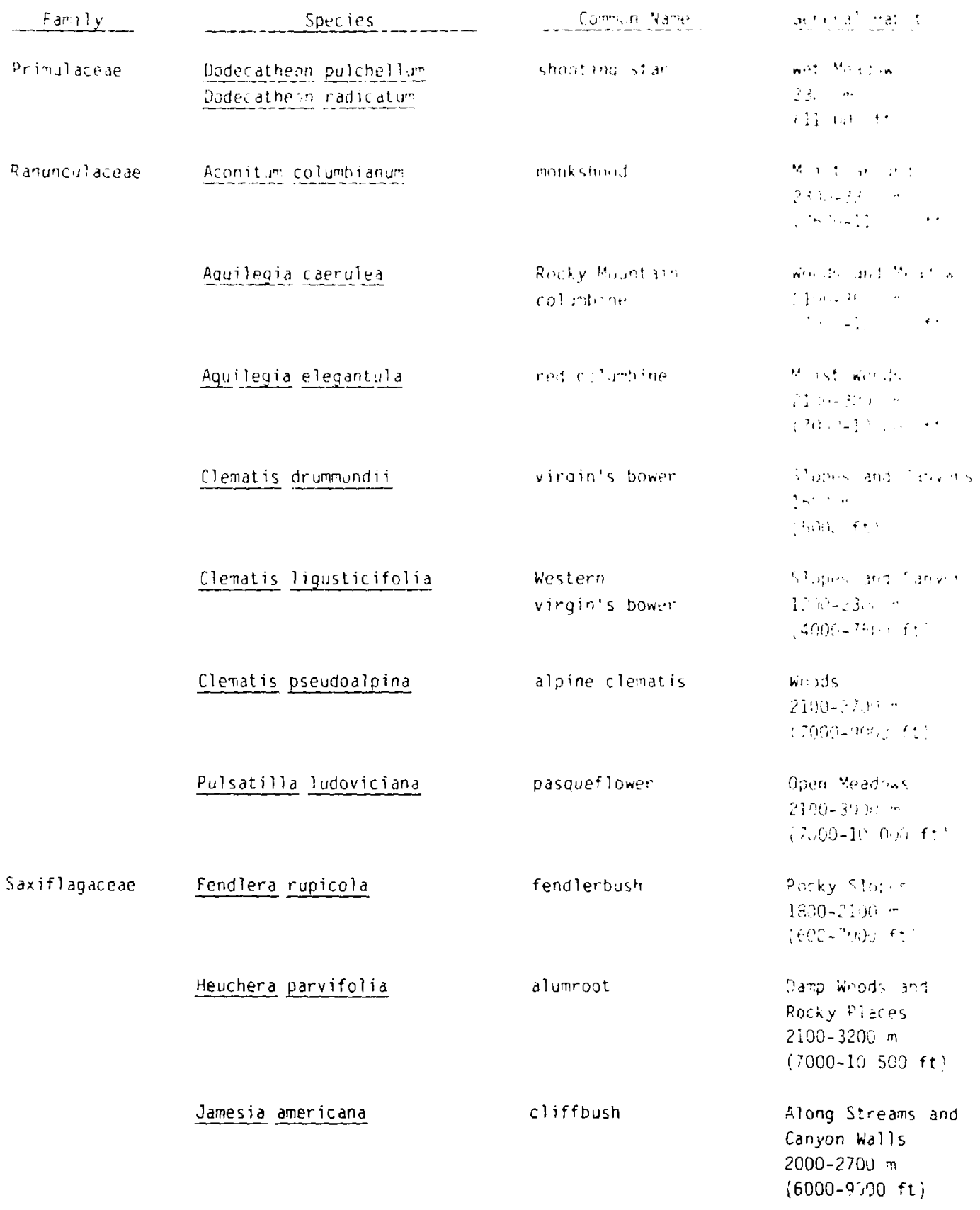




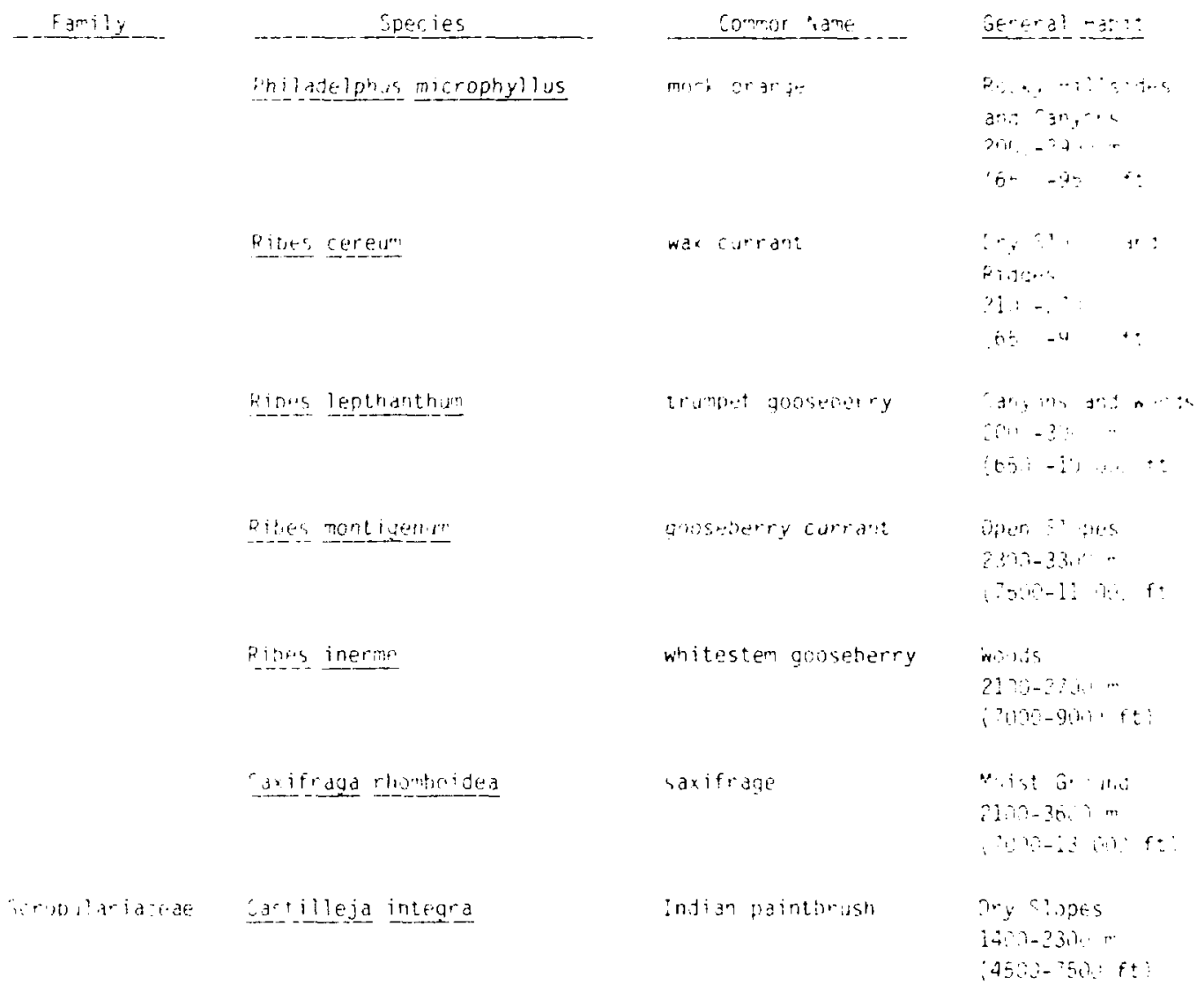




\section{APPENDIX [)}

ANIMALS OF THE LOS ALAMOS FNVIROHS

${ }^{\text {a Taken from Los } A l a m o s ~ S c i e n t i f i c ~ L a b o r a t o r y, ~ " F i n a l ~ E n v i r o n m e n t a l ~ I m p a c t ~}$ Statement," Department of Energy report DOE/EIS-0018 (December 1979). 
TABEE

MinMASA:

\begin{tabular}{|c|c|c|}
\hline $\begin{array}{c}\text { ver if led } \\
\text { to } 8 e\end{array}$ & $\begin{array}{l}\text { irecrora } \\
\text { repordeg in }\end{array}$ & 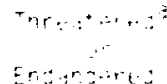 \\
\hline
\end{tabular}

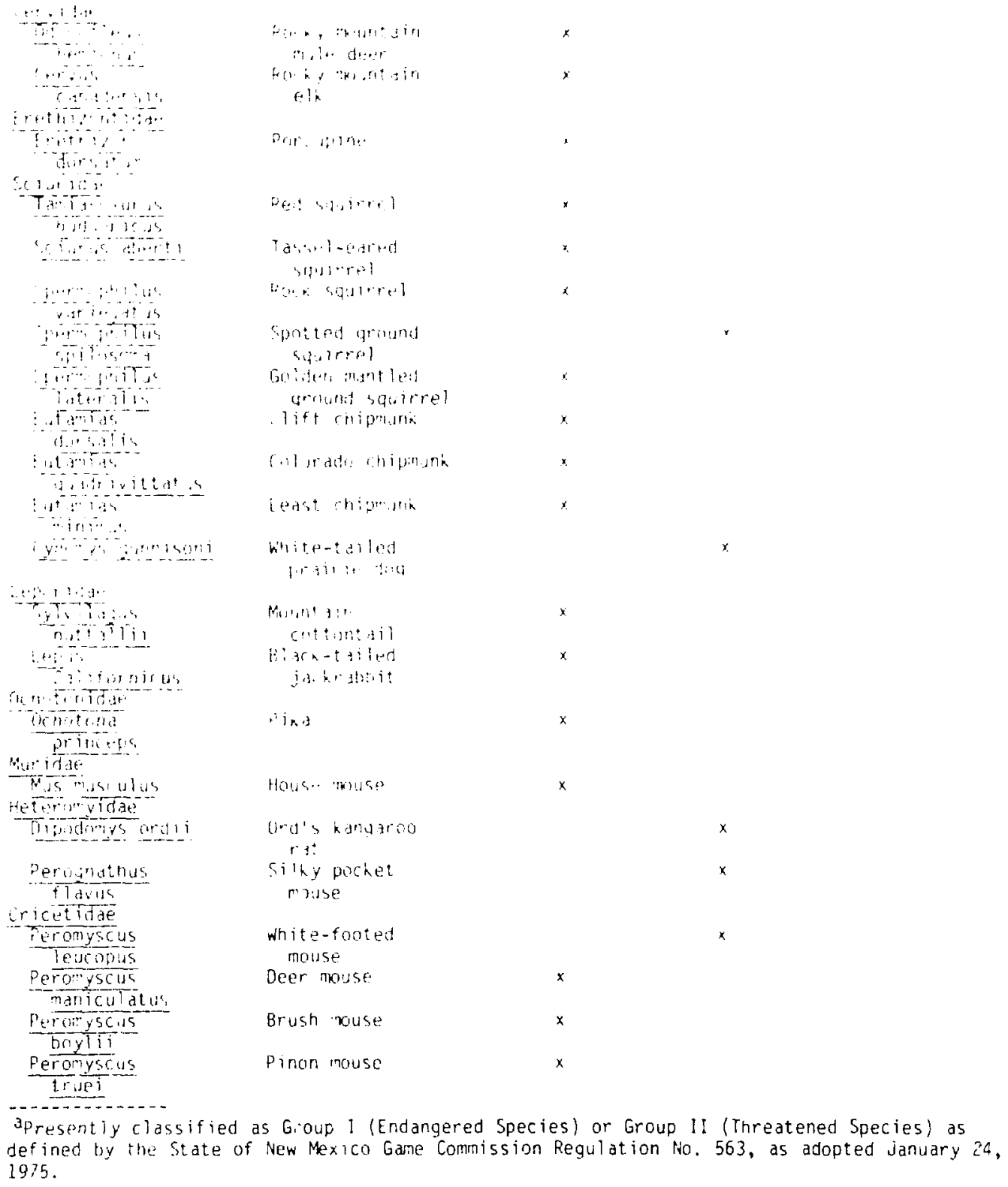




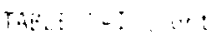
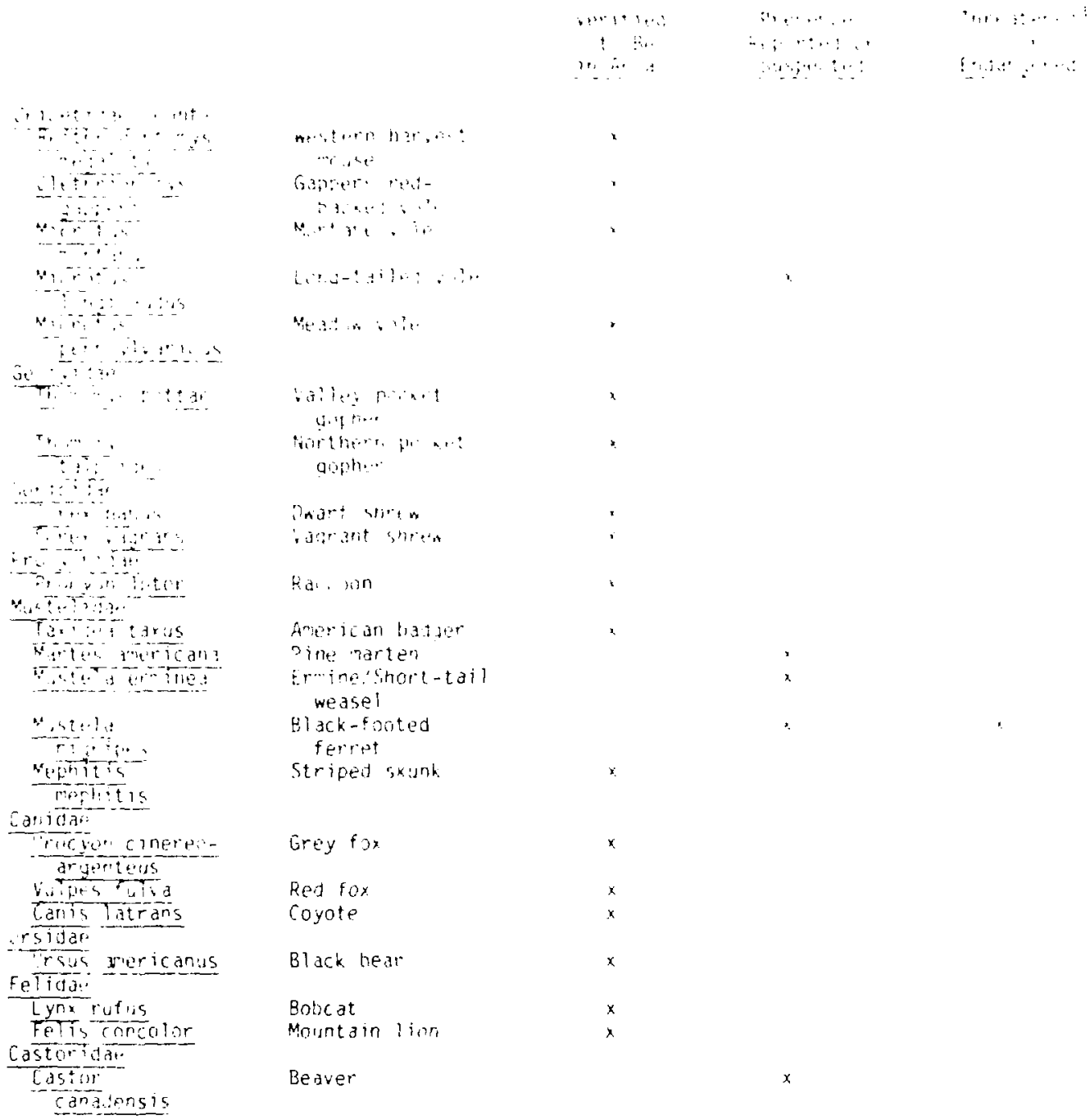

$x$

90 


\begin{tabular}{|c|c|c|c|c|}
\hline & & $\begin{array}{c}\text { Verified } \\
\text { to Be } \\
\text { in Area } \\
\end{array}$ & $\begin{array}{l}\text { Presence } \\
\text { Reported or } \\
\text { Suspected } \\
\end{array}$ & $\begin{array}{c}\text { Threatened } \\
\text { or } \\
\text { Endangered }\end{array}$ \\
\hline \multicolumn{5}{|l|}{ Plethodontidae } \\
\hline Tei idae & sal amander & & & \\
\hline Iguanidae & Whiptail & $x$ & & \\
\hline Phrynosoma spp. & Horned lizard & $\mathrm{x}$ & & \\
\hline$\frac{\text { Crotaphytus }}{\text { collaris }}$ & Collared lizard & $\mathrm{x}$ & & \\
\hline Sceloporus & Desert spiny & $x$ & & \\
\hline Viperidas & lizard & & & \\
\hline$\frac{\text { crotalus }}{\text { viridis }}$ & Prairie rattlesnake & $x$ & & \\
\hline$\frac{\text { Colubridae }}{\text { Pituophis }}$ & & & & \\
\hline$\frac{\text { Pituophis }}{\text { me:anoteucas }}$ & Bull snake & $x$ & & \\
\hline$\frac{\text { Thamnophis }}{\text { sirtalis }}$ & $\begin{array}{l}\text { Common garter } \\
\text { snake }\end{array}$ & $\mathrm{x}$ & & \\
\hline Thamnophis & Western garter & $x$ & & \\
\hline elegans & snake & & & \\
\hline$\frac{\text { LampropeTt is }}{\text { getulus }}$ & $\begin{array}{l}\text { Common king } \\
\text { snake }\end{array}$ & $x$ & & \\
\hline
\end{tabular}


TABLE D-III

FISH

\begin{tabular}{ccc}
$\begin{array}{c}\text { Verified } \\
\text { to Be } \\
\text { in Area }\end{array}$ & $\begin{array}{c}\text { Presence } \\
\text { Reported or } \\
\text { Suspected }\end{array}$ & $\begin{array}{c}\text { Threatened } \\
\text { or } \\
\text { Endangered }\end{array}$ \\
\hline
\end{tabular}

Catostomidae

Catostomus

commersoni

Carpoides carpio Carp-sucker

Cyprinidae

Cyprinus carpio

Hybopsis spp.

Salmonidae

Salmo trutta
White sucker

Carp

Chub

Brown trout $x$

$x$

$x$ 
TAELL U-IV

BIROS

\begin{tabular}{|c|c|c|c|c|c|}
\hline $\begin{array}{l}\text { fest } \\
\text { in } \\
\text { Area }\end{array}$ & $\begin{array}{l}\text { Summer } \\
\text { Resident }\end{array}$ & $\begin{array}{l}\text { Yearlong } \\
\text { Resident }\end{array}$ & $\begin{array}{l}\text { niriter } \\
\text { Resident }\end{array}$ & Migrant & $\begin{array}{l}\text { iased or } \\
\text { Irrez-iar }\end{array}$ \\
\hline
\end{tabular}

Gavifirmes

Gacid Tomer

pidicep caspicus

Anseriforites

Erant a canadens is

Aras platyrhynchos

Arras strepera

Ands dcuta

Thas carolinensis

तincs discors

inas cyanopter

Marera americana

Spatula clyoeata

inting collaris

Fytiya affinis

Bucepha!d alberala

Oxyura jonaticensis

Mergus merganser

a a coniformes

Cathartes aura

Accipiter gentilas

Accipiter striatus

Acciplter coaperis

Stted jamaicensis

Buteo albonot atus

E.tec Tagopus

3.ter regatis

injla chrysaetos

Bircus cyaness

Trictor halidetus

Falce rexicanas

Taco peregrinus

Jac colutbarius

eacc soarverius

ua ifores

vetragan

ascorus

a inejia

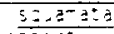

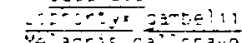

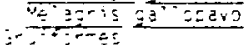

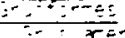

$\therefore-i$ zentiona

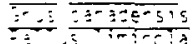

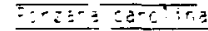

Common loon

Eared grebe

Canada yoose

Mallara

Gadwall

Pintail

Green-winged teal

Blue-winged tea!

Cinnamar teal

American widgean

Shoveler

Ring-neckeo duck

Lesser scaup

Bufflehead

Ruddy duch

Common inerganser

Turkey vulture:

Goshawk

Sharp-shinned hawk

Conper's hawk

Red-tailed hawk

Zone-tailed hawk

Rough-legged nawk

Feriugirious hawk

Goluen eaqle

Marsh hawk

Osprey

Prairie falcont

Peregrine falcon ${ }^{b}$

Mer lin (pigeon hawk)

American kestrel

Bìue grouse

Resident

Resident

Resident

Migrant

Irregiar

$\therefore-1 . .$.

Scaled quail

Gambel's quail

wild turkey

whooping crane ${ }^{c}$

Sandhill crane

birginia rail

Sora

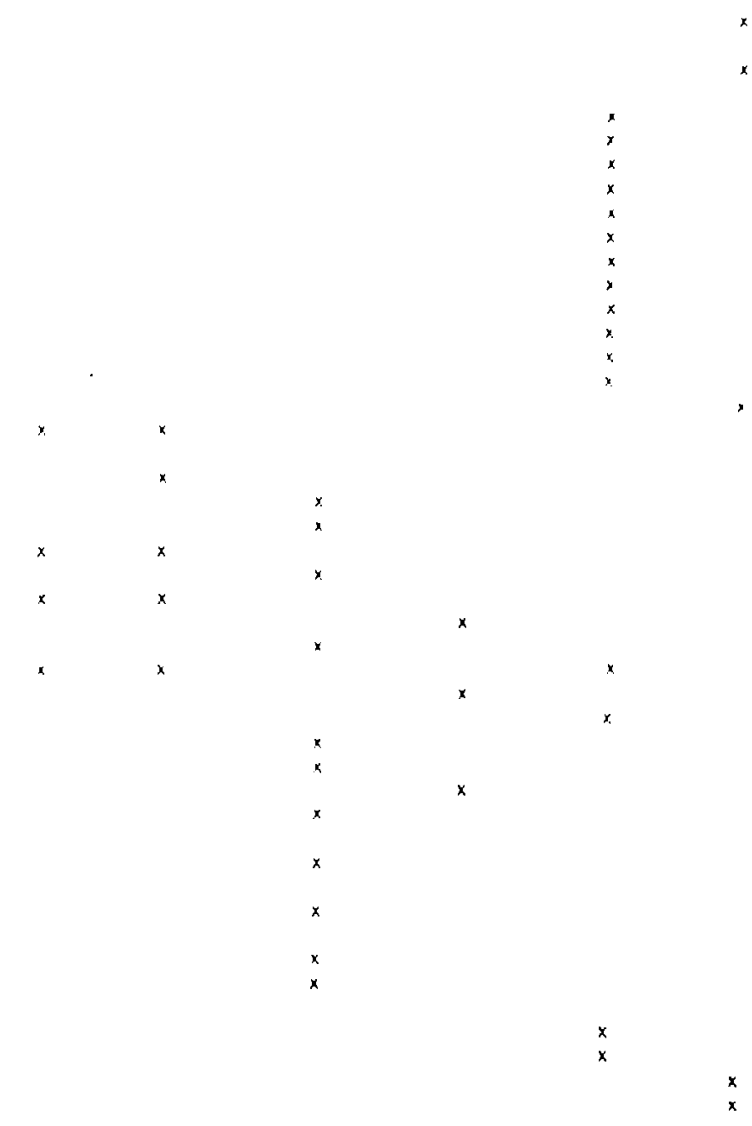

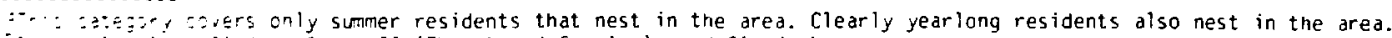

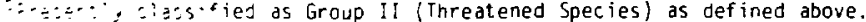

$:=: \div ;,: \geq s 5 \times$ ied as Group I (Endangered Species) as defined by the State of New Mexico Game Conmission Regulation iNo. $\because: \quad \vdots:$ : 
TABLE D-IV (cont)

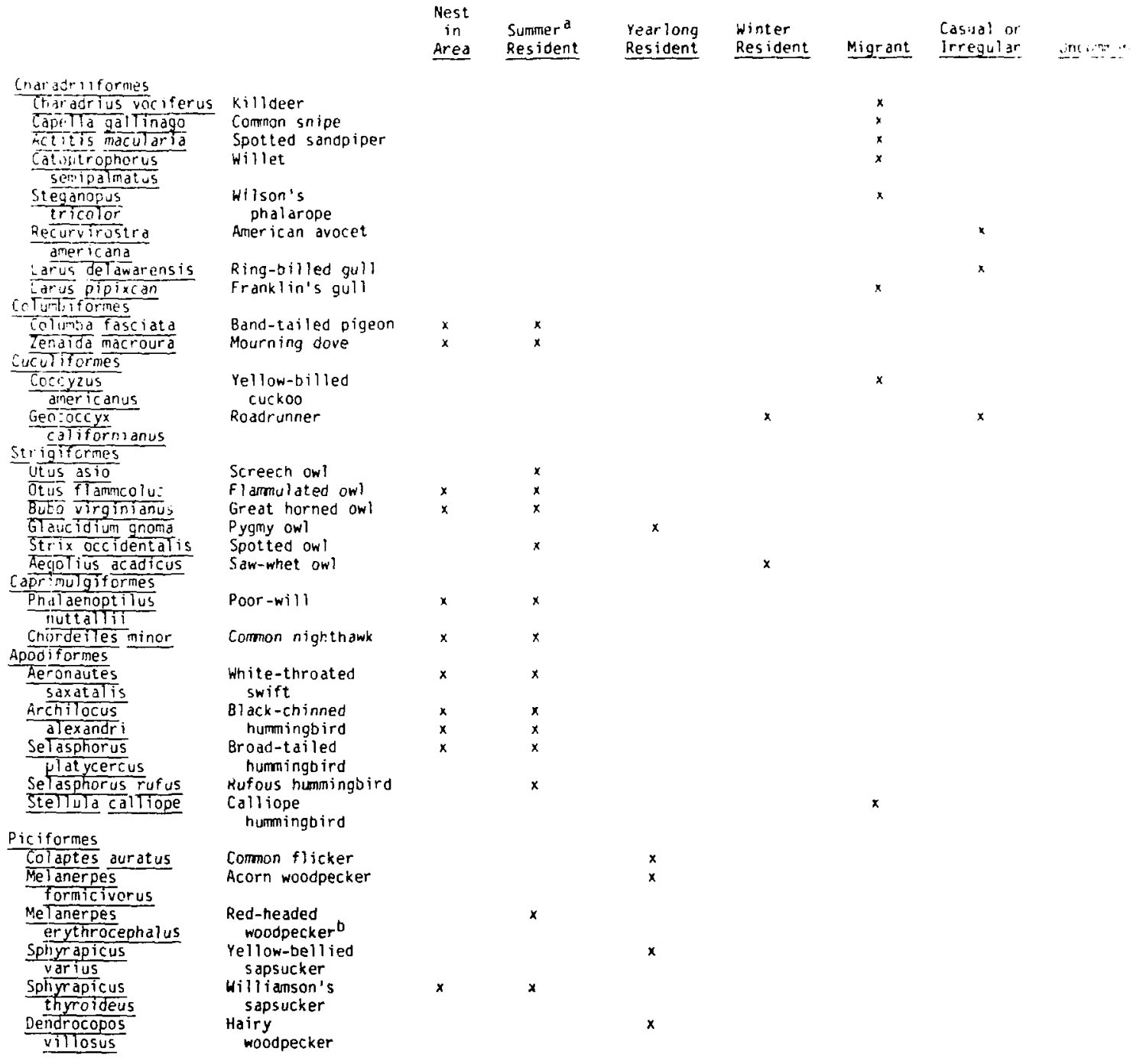


TABLE D-IV (cont)

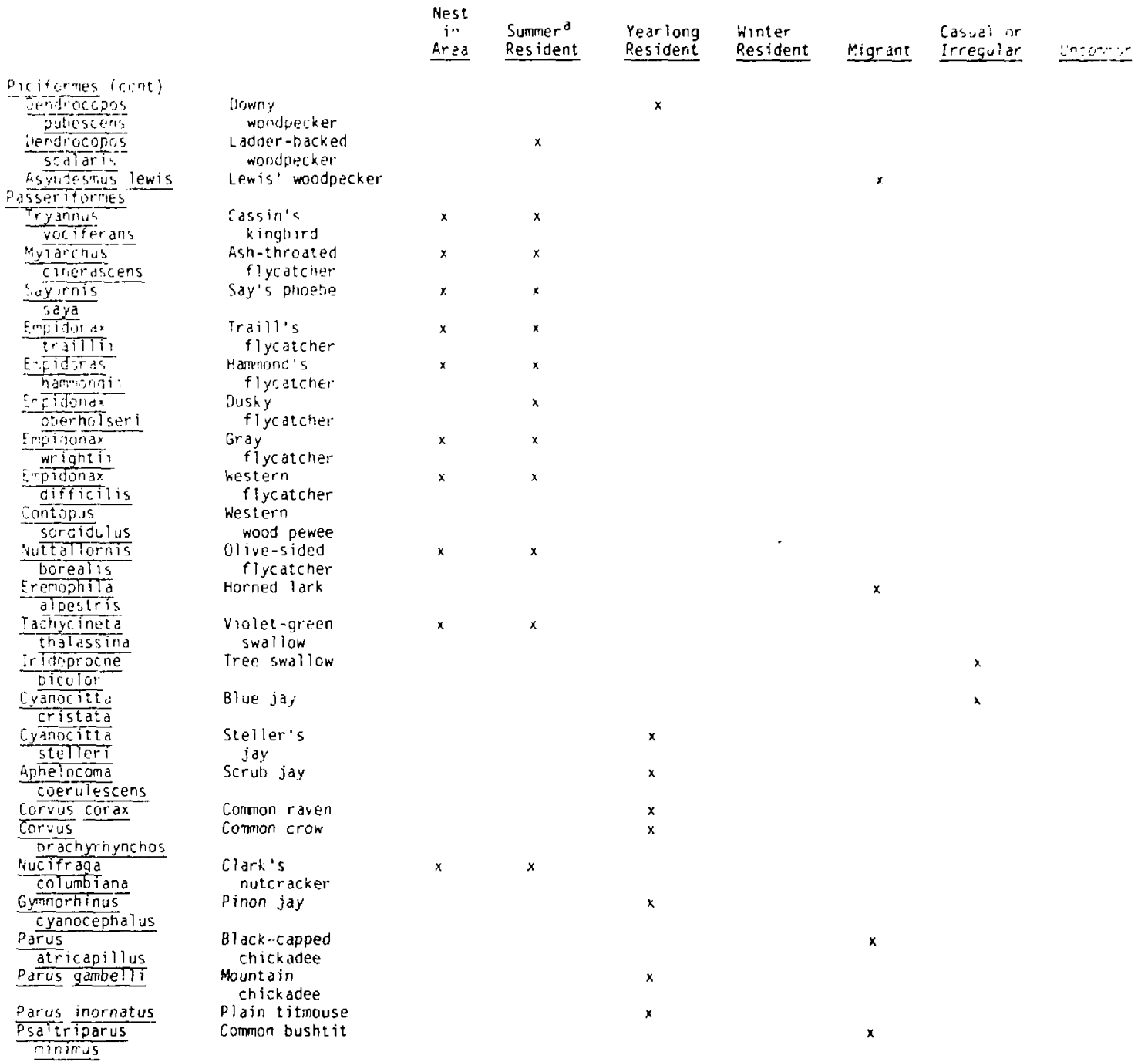


TABLE D-IV (cont)

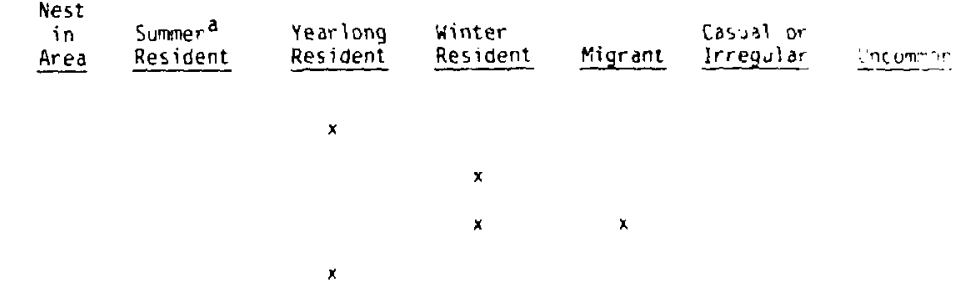

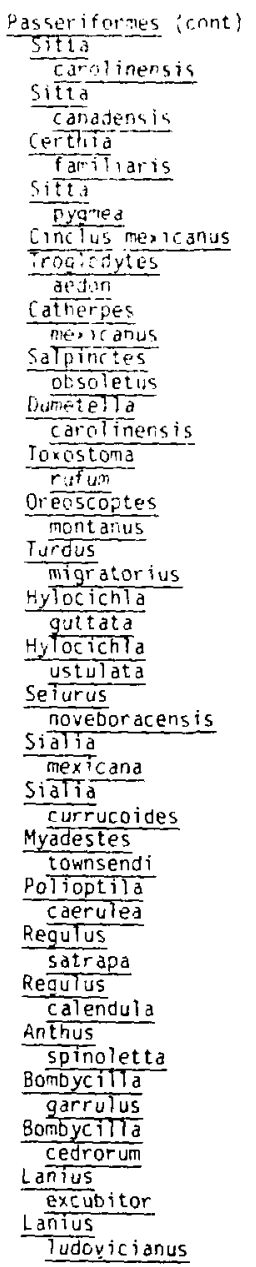

White-breasted nuthatch Red-breasted nuthatch

Brown creeper

Pyọmy nuthatch

Dipper

House wren

Canyon wren

Rock wren

$x$

Catbird

Brown

thr asher

Sage thrasher

$x$

$x$

Robin

Hermit

thrush

Swainson's

thrush

Northern

waterthrush

Hestern

bluebira

Mountain

bivebird

Townsend's

solitaje

B lue-gray

gnatcatcher

Golden-crowned

kinglet

Ruby-crowned

kinglet

Water pipit

Bohemian

waxwing

Cedar

waxwing

Northern

shrike

loggerhead

shrike

$x$

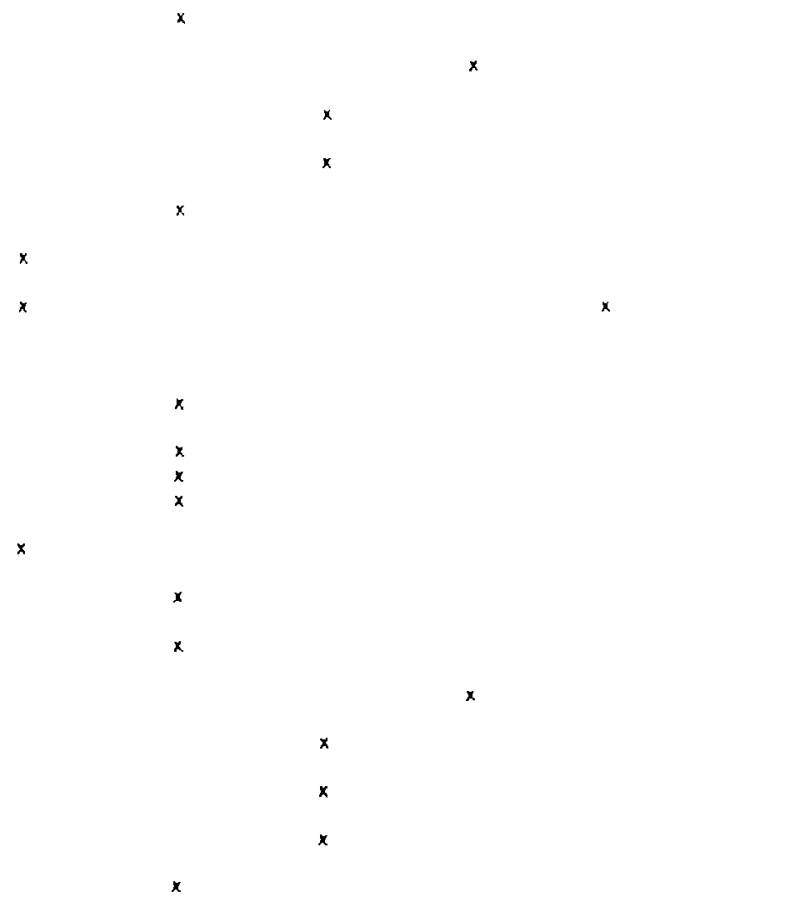


TABLE O-IV (cont)

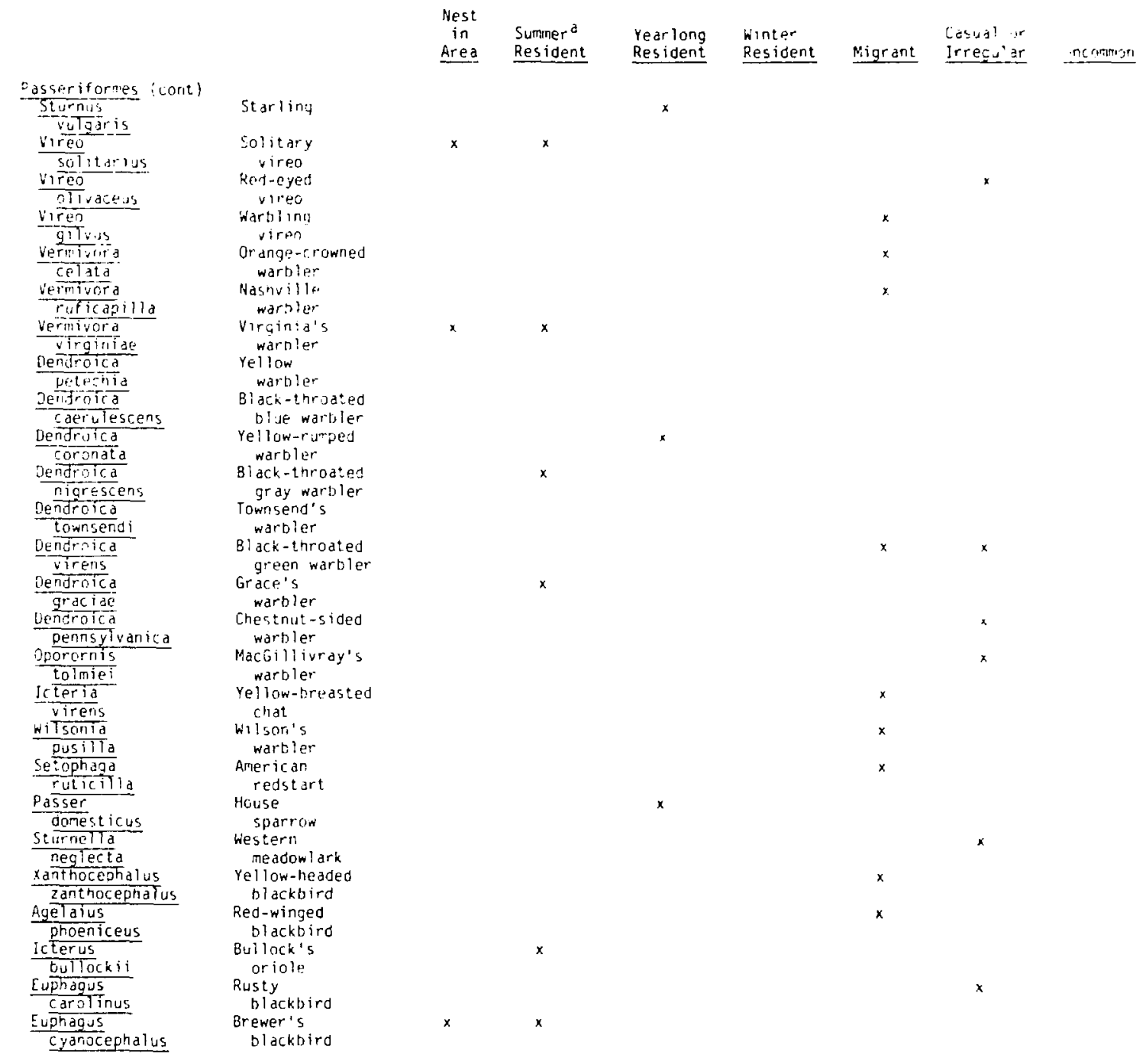


TABLE D-IV (cont)

\begin{tabular}{|c|c|c|c|c|c|}
\hline in & $\begin{array}{l}\text { Summer }{ }^{\mathrm{a}} \\
\text { Resident }\end{array}$ & $\begin{array}{l}\text { Yearlony } \\
\text { Resident }\end{array}$ & $\begin{array}{l}\text { Winter } \\
\text { Resident }\end{array}$ & Migrant & $\begin{array}{l}\text { Casual or } \\
\text { lrregular }\end{array}$ \\
\hline
\end{tabular}

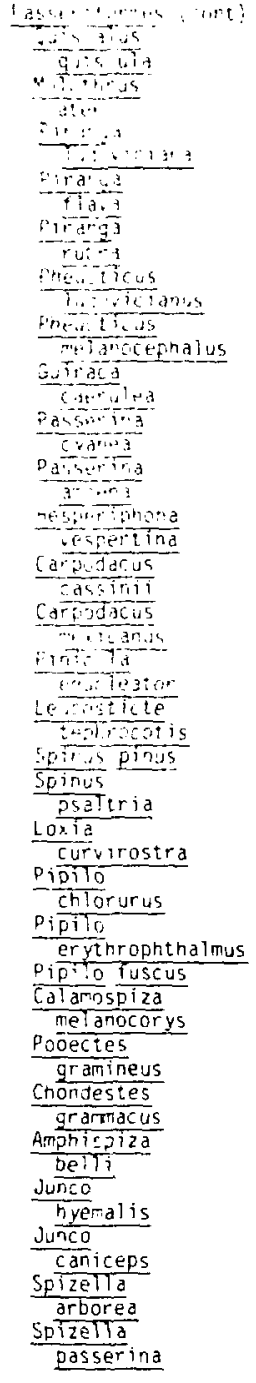

Crimon

grackle

Brown-headed

cownird

weterti

inager

Hepatic

tanager

sumples

tanager

Rose-breasted

grosbeak

Bl ack-headed

grosbeak

Blue

grosueak

Indigo

bunting

Lazui

bunting

Evening

arosbeak

Cassin's

finch

House

sinch

Pine

grosbeak

Gray-crowned

rosy finch

Pine siskin

Lesser

goldf inch

Red

crossbill

Green-tailed

towhee

Rufous-sided

towhee

Brown towhee

Lark

bunt ing

Vesper

sparrow

Lark

sparrow

Sage

sparrow

Dark-eyed

junco

Gray-headed

junco

Tree

sparrow

Chipping

sparrow
Resident
Resident
Migrent Irregular

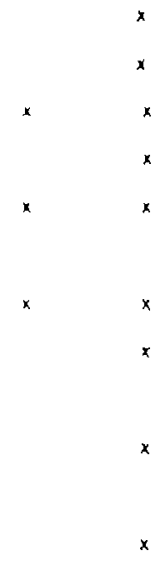

$x$

$x$

x

$x$

$x$

$x$

$x$

$x$

$x$
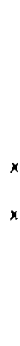
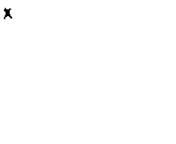

$x$

\section{$x$}

$x$

$x$

$x$ 
TABLE D-IV (cont)

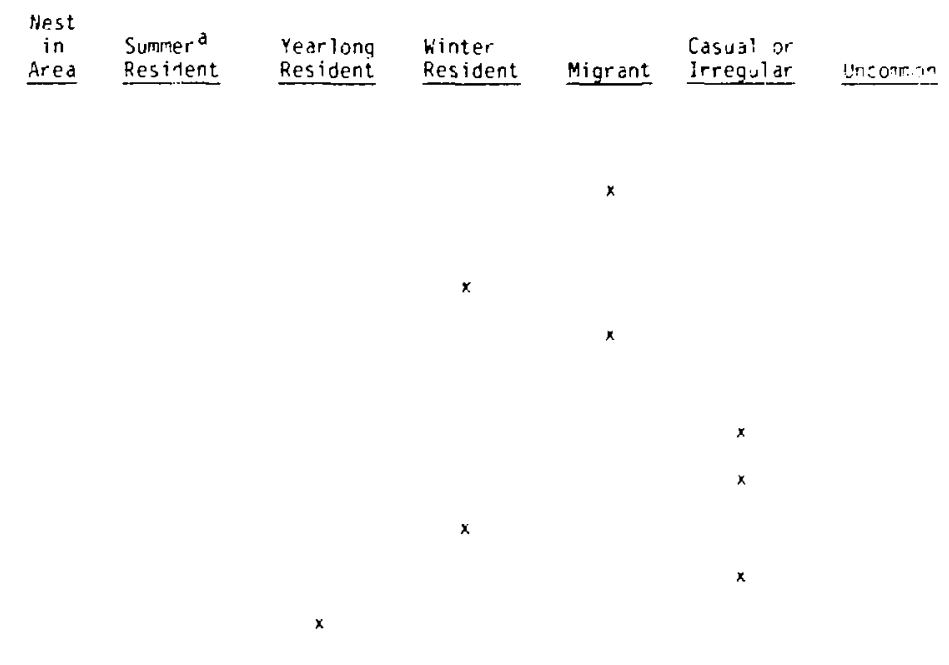




\begin{tabular}{|c|c|c|c|}
\hline Phylum & Class & Order & $\begin{array}{l}\text { Estimated } \\
\text { No. Species } \\
\end{array}$ \\
\hline Annelida & $\frac{01 \text { igochaet a }}{\text { (segmented rorms) }}$ & & 1 \\
\hline Nematomorpina & $\frac{\text { Gordi aceae }}{\text { (round worms) }}$ & & 2 \\
\hline \multirow[t]{24}{*}{ Arthropoda } & $\begin{array}{l}\text { Chi lopoda } \\
\text { (cent ipedes) }\end{array}$ & & 5 \\
\hline & $\frac{\text { Diplopoda }}{\text { (millipedes) }}$ & & 1 \\
\hline & Arachnida & $\frac{\text { Acarina }}{\text { (ticks and mites) }}$ & $>80$ \\
\hline & & $\frac{\text { Solpugida }}{\text { (sun "scorpions") }}$ & 1 \\
\hline & & $\begin{array}{l}\text { Che Tonethida } \\
\text { (fatse scorpions) }\end{array}$ & 1 \\
\hline & & $\frac{\text { Phal angida }}{\text { (Harvestmen) }}$ & 1 \\
\hline & & $\begin{array}{l}\text { Araneida (spiders) } \\
\text { (16 families) }\end{array}$ & $74-100$ \\
\hline & Insects & Thys anura & 1 \\
\hline & & Collembola & $\begin{array}{c}32-37 \\
4-6\end{array}$ \\
\hline & & $\frac{\text { Urthoptera }}{\text { Psocoptera }}$ & $\begin{array}{l}4-b \\
j-4\end{array}$ \\
\hline & & Thysanoptera & $4-6$ \\
\hline & & Hemiptera & $28-33$ \\
\hline & & Homoptera & $18-23$ \\
\hline & & Coleoptera & $46-51$ \\
\hline & & Mecoptera & 1 \\
\hline & & Neuropter a & $3-5$ \\
\hline & & Rhaphidioidea & $\begin{array}{l}1 \\
1\end{array}$ \\
\hline & & $\frac{\text { richoptera }}{\text { Ledidoptera }}$ & $9-12$ \\
\hline & & Diptera & $50-57$ \\
\hline & & Siphonaptera & $2-3$ \\
\hline & & $\frac{\text { Hymenoptera }}{\text { (Formicidae }} 22-25$ ) & $54-65$ \\
\hline & & Protura & 1 \\
\hline & & Diplura & 3 \\
\hline & & Total No. Species & $430-535$ \\
\hline
\end{tabular}

